\title{
Gender Inequalities and Demographic Behavior: Egypt [Arabic]
}

Nora Guhl Naguib

Cynthia B. Lloyd

Population Council

Barbara L. Ibrahim

Population Council

Follow this and additional works at: https://knowledgecommons.popcouncil.org/departments_sbsr-pgy How does access to this work benefit you? Let us know!

\section{Recommended Citation}

Naguib, Nora Guhl, Cynthia B. Lloyd, and Barbara L. Ibrahim. 1996. "Gender Inequalities and Demographic Behavior: Egypt [in Arabic]." Cairo: Population Council. 


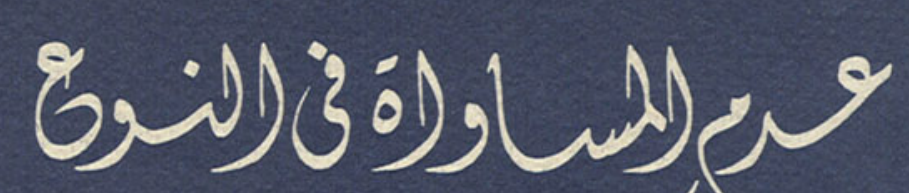

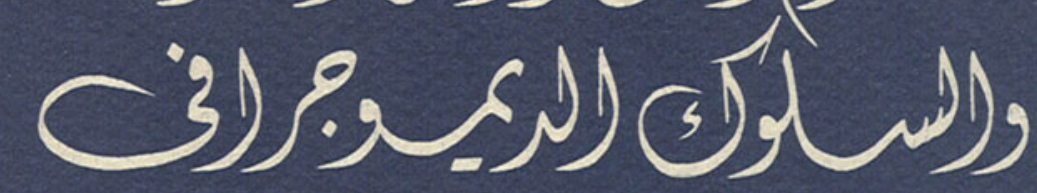

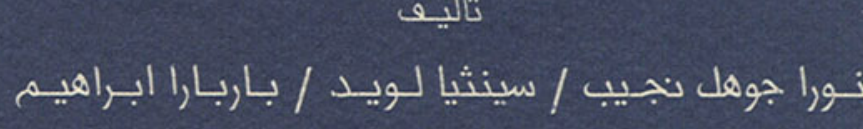





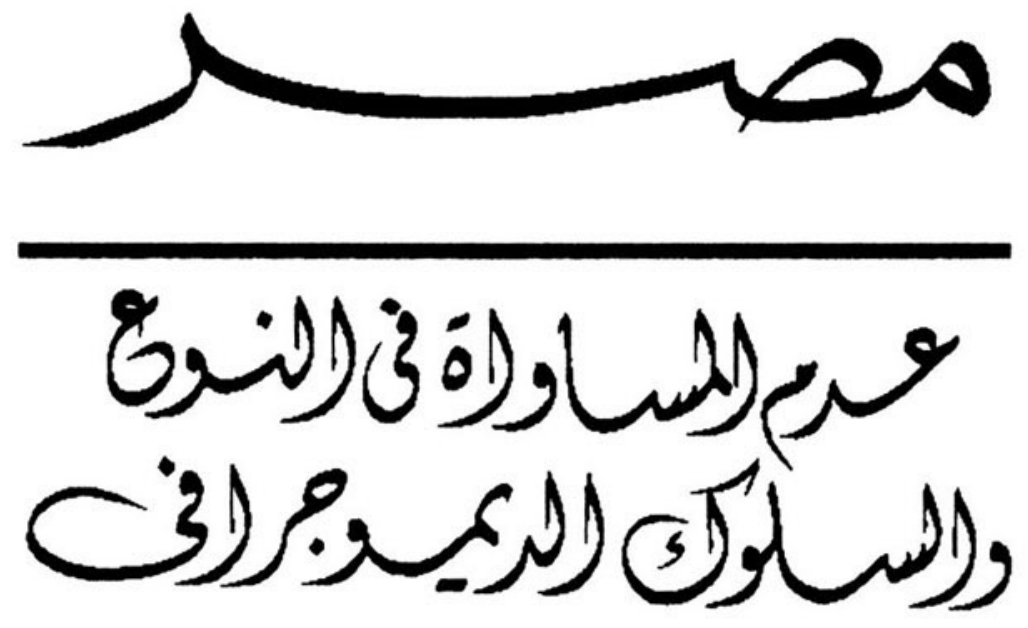

$$
\text { نورا جوهل نجيب / سينيّا لويد / باربارا إبراهيم }
$$

$$
\text { مشيرة الجحسزيرى ترير }
$$




$$
\text { صجلس السكان الدولى } 110
$$

بسعى مجلس السكان السى تحسبن رفاهية الأجيال الحالية والقادمة وصدتها

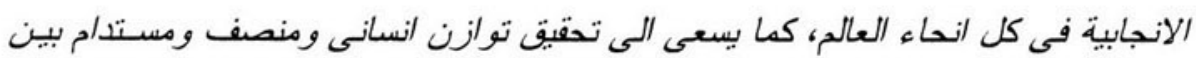
السكان و الموارد. وللمجلس - وهو منظمة بحثية غير حكومية ولاتسعى الى تحقيق الربح

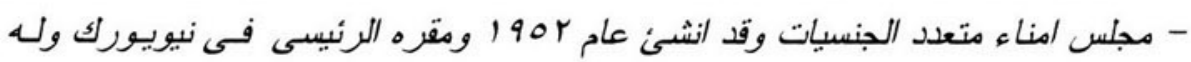

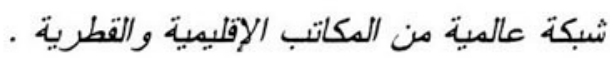

$$
\text { نورا جوهل نجيب: مستشار لمجلس السكان الدولى. }
$$

سينثيا لويي: خبير مشارك ونائب مدير قسم الابحاث بمجلس السكان الدولى بنيويورك . باريارا ابراهيم: المدبير الاقليمى لمجلس السكان الدولى فى منطقة غرب آسيا وشمال افريقيا.

تشكر المؤلفات كلأ من كارلا مخلوف اوبرماير وكارولين ماكينسون وأحمد رجاء رجب وعزة سلبمان ورندا ابراهيم لتعليقاتهم المفيدة على الكتاب.

يجوز تصوبير او اقتباس أى جزءء من هذا الكتاب لتلبية الاحتياجات المحلية

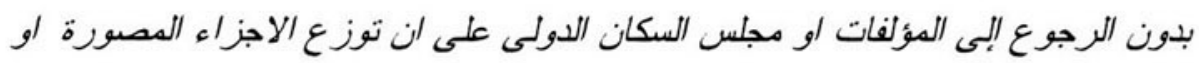

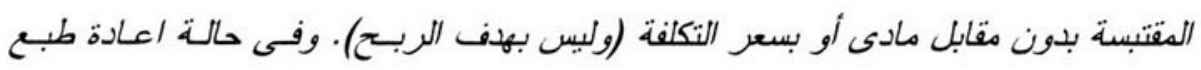
ذات صفه تجارية، يجب الحصول على موافقة مجلس السكان الدولى المسبقة. كما تـأل لـل

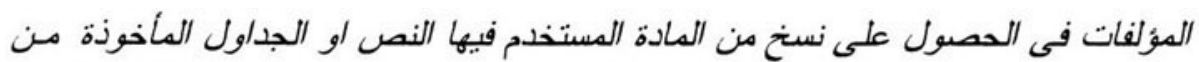
هذا التقربير . حقوق الطبع 1997 ـ ـ مجلس السكان الدولى. 


\section{المحتويات}

تصدير

تمهيد الطبعة العربية

$r$

$\wedge$

9

10

11

استقلالية المر أة فى العلاقات الحميمة وصنع القرارات الجنسية والانجابية

ro

rV

rq

Tr

rv

rA

\&0

$\varepsilon \vee$

o.

7.
المشكلة السكانية واستجابة الحكومة

عدم المساواة فى النوع داخل الاسرة

الجوانب القانونية والعرفية للزواج

أنماط الزواج وتدابير الحياة الاسرية

تقسيم المسئوليات و الموارد
دلالات عدم المساواة فى النوع داخل الاسرة على السلوك الديموجر افى

التعليم

العمل

دلالات تغير أدوار النوع فى الحياة العامة على السلوك الديموجر افى

عدم المساواة فى النوع فى تقديم خدمات الصحة الانجابية

دلالات أوجه عدم الانصاف فى نقديم الخدة على الإختيار الإنجابى

عدم المساو اة فى النوع فى الحياة العامة

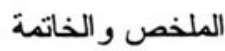

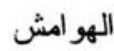

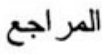




\section{تصديز}

هذا الكتاب هو أحد ثلاث تقارير تدور جميعها حـول العلاقـة بين الانصساف فى النوع وتزكيب الاسرة وديناميكياتها وتحقيق الخيار الانجابى. هذا وقد قام باعداده مجلس السـكان الدولى بمناسبة العام الدولى للأسرة و المؤتمر الدولى للسكان و التتمبة سـنة ع و ا ـ ـ وتقدم

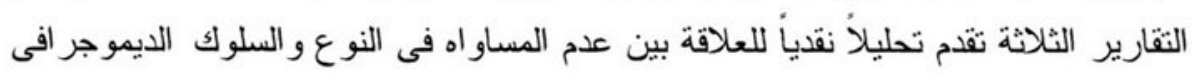
فى ثلاث مناطق هامة ديموجر افيا وبارزة ثقافيا فى العالم الثالث وهى: ( ) مصر و r) الهند و r) غانـا وكينيـا. وتهـدف التقارير إلى مسـاعدة الحكومـات و المنظمـات الغبر حكومبـة و الجهات الدولية فى تصميم وتنفيذ السياسات التى تتسم بموقفها الإيجابى تجاه النساء آخذذة فى الإعتبار الدور الرئيسى للأسرة فى تحديد وتوزيع الموارد وفعاليتها فى تحقيق اهداف سكانية وتتمويه و اسعة النطاق لرون

و اصدر مجلس السكان الدولى كتيباً مصاحباً لهذه التقارير ضمن سلسـلة "أوراق القضايـا" حول اللمساو اه فى النوع و التغير الديموجر افى، مقدمأ جدول اعمال للسياسـات السـكانية،

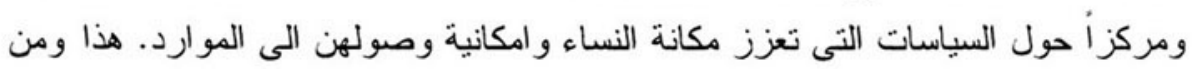

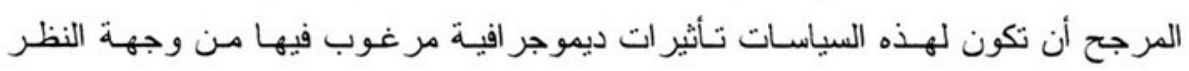
التنموية.

وقد كان للمساندة الكريمة التى قدمها صندوق الامم المتحـدة للانشـة السـكانية بنيويـورك (المشروع رقم INT/92/P57) المعروف باسم "الاسرة و السياسة السكانية: نحو تحقيـق الخيار الانجابى الكامل" الفضل فى انمام سلسلة التقارير هذه. 


\section{تمهيد للطبعة العربية:}

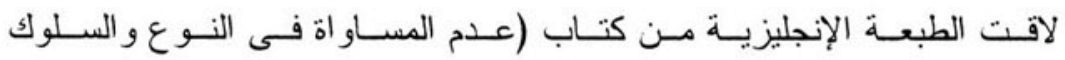

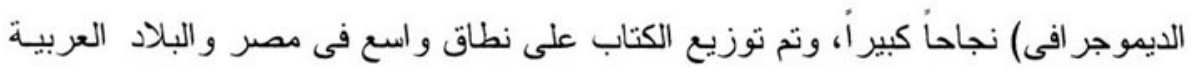

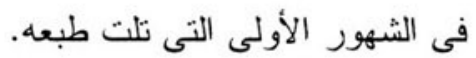

ونظر ألإقبال المنقفين و الباحثين العرب على منشور ات مجلس السكان باللغة

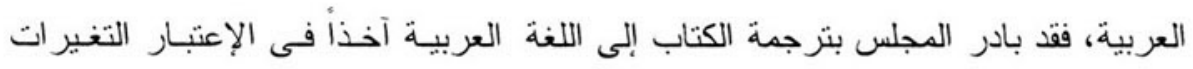

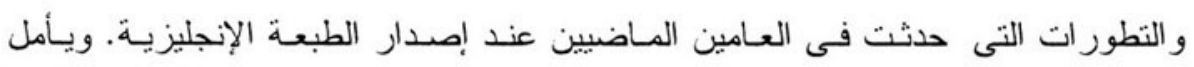

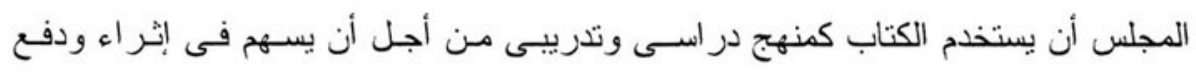
الحوار حول القضايا الهامة الخاصة بالنوع و العمليات الديموجر افية والتمية الإجتماعية.

باربارا ابر/هيم

القاهرة، سبتمبر 1997 
تمر مصر حاليـا بتغير ات ديموجر افيـة سريعة، فالانخفاض في الوفيـات يصاحبـه الآن

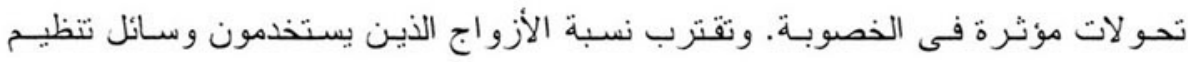
الأسرة - و التى تضاعفت فى الثمانينيات- مـن نسبة ال ـ0\% (المجلس القومي للسكان

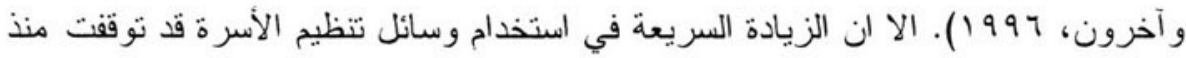

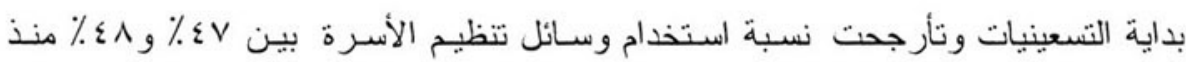

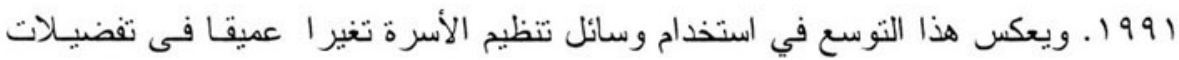

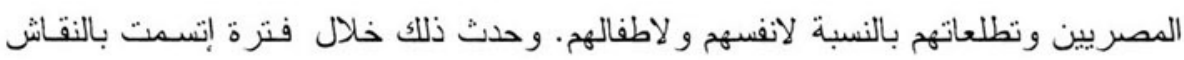

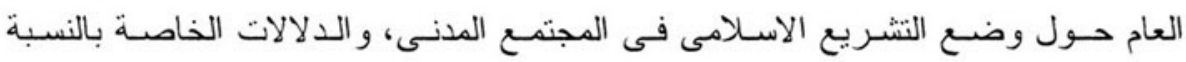

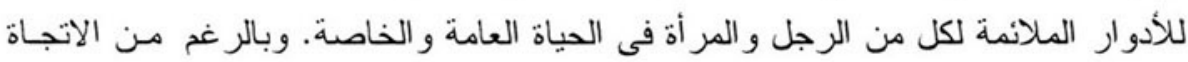

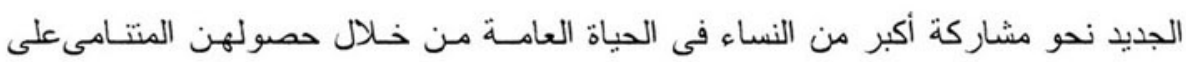

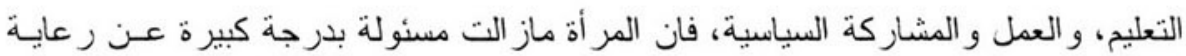

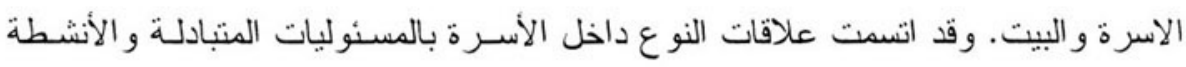

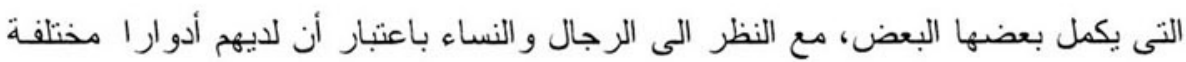

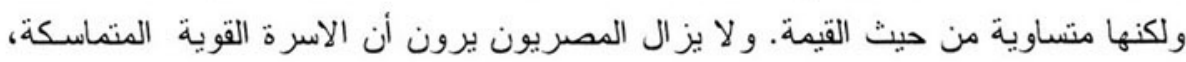

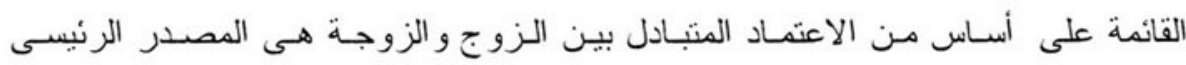

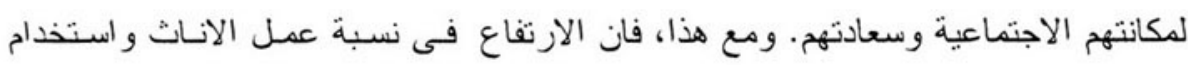

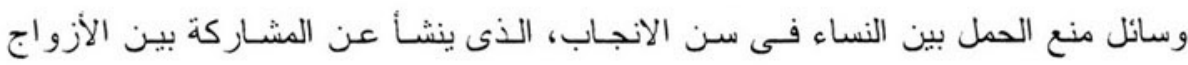

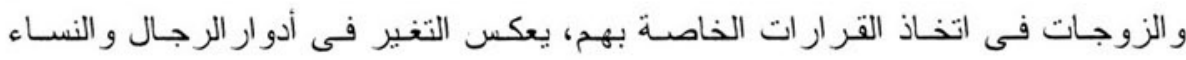

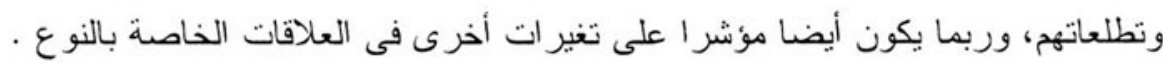

ويوجد فى مصر حاليا توتر ا جوهريا بين حقوق النساء المدنيـة و السياسية كمـا

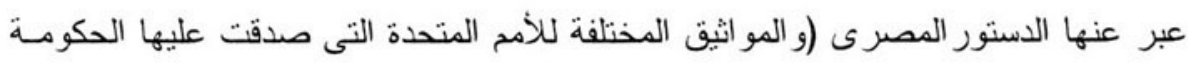
المصرية) وبين حقوق النساء داخل الأسرة كما حددها قانون الأحوال الشخصية الاسلامى لإنى 


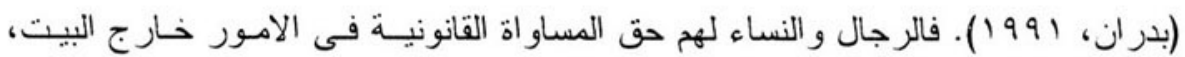

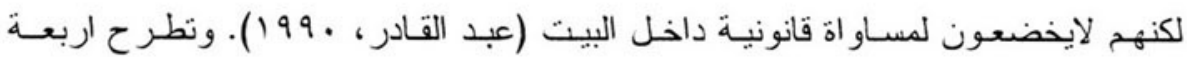
مجالات فى قانون الاحوال الشخصية الحالى، على وجه الخصوص، اشكاليات أمام النساء المصريات المسلمات. و هذه المجالات هى: 1- حقوق الزوج المطلقة فى أن بطلق زوجته

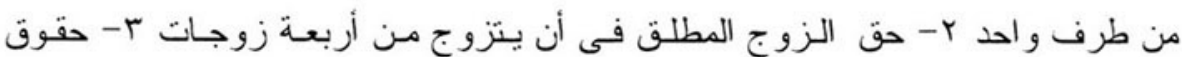

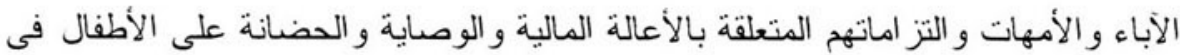

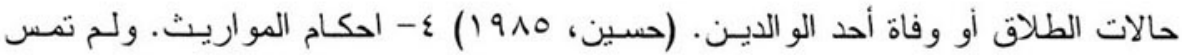

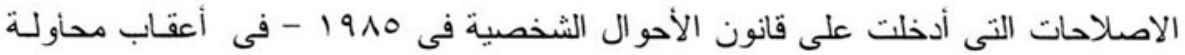

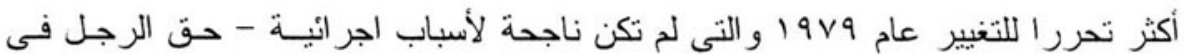

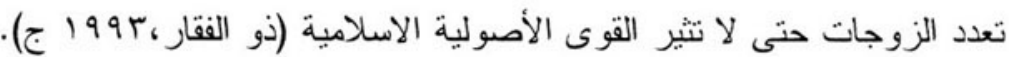

وفى خلال منتدى دولى عقد لمناقشة تحفظات مصر على المادة 17 من الاتفاقيـة الدولية للقضاء على كافة اثكال التمييز ضد المر أة و التى تشترط مساو اة الرجـال و النسـاء

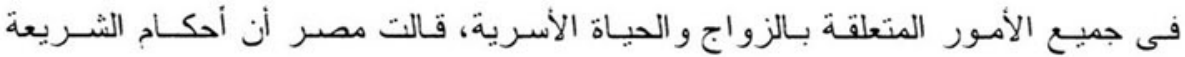
الاسلامية يجب أن تسود فيما يخص الامور الاسرية وأن النشريع الاسـلامى الذى يحكم

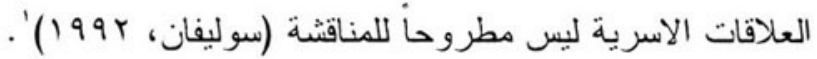

ويهدف هذا التقرير الى بحثث السياقين القانونى و الاجتمـاعى و السياق الخـاص برسم السياسات الذى تعمل فى نطاقه العلاقات الخاصة بالنو ع فى مصر ـ كما يهـف الى لى

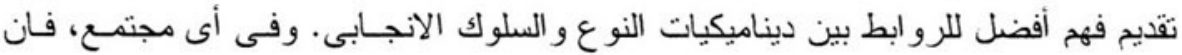

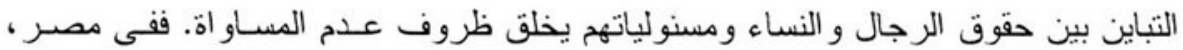

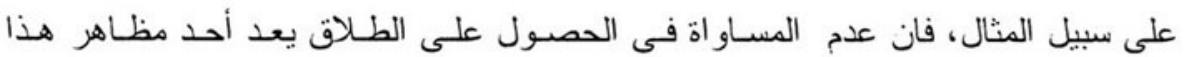
التباين. ويستخدم هنا لفظ "عدم المساو اة" بمعناه الموضوعى الو اقعى - ونشبر مع هذا الى لى لـ بعض الأثار الايجابية و السلبية لعدم المساو اة كما عبر عنها الكتاب و الباحثُون المصريون.

وتتضمن سياسات الحكومة السكانية - التى لا تشتمل، فى الحالة المصرية، على

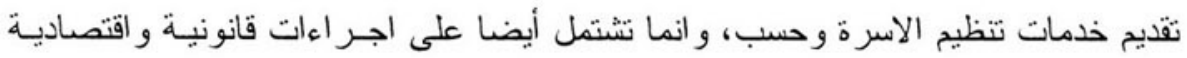
- بعض الافتر اضات الخاصة بالأسرة وبالدور الـــى يلعبـه الرجـال و النسـاء فيهـا (لويـد،

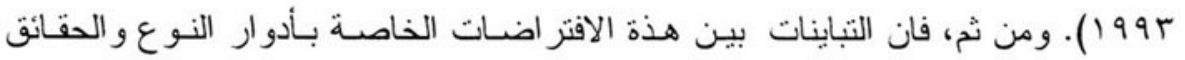


المعاصرة، تصبح جز ءا مهما من القصة. فمنذ الستينيات، كانت للحكومة المصرية سباسـة

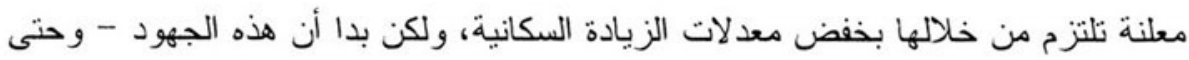

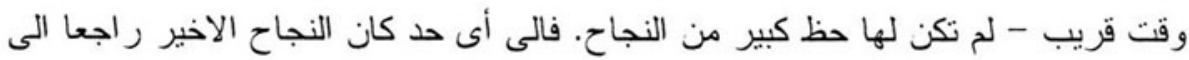
سياسات أكثر و اقعية وكذلك الى تغير ات أكثر جو هرية فى الحياة الاقتصـاديـة والأسـرية ؟

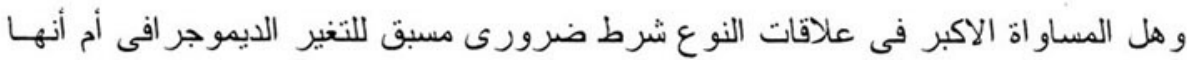
- فى السياق المصرى - ناتج محنمل عنه؟

وللاجابة على هذه التساؤلات، فان التقرير يستكشف أوجـه عدم المسـاو اة داخلـ

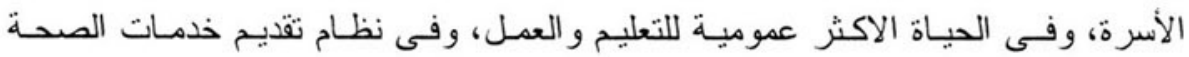

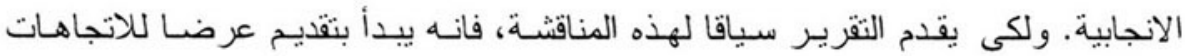

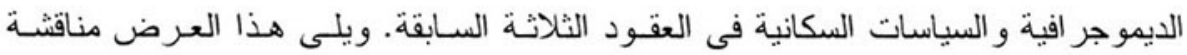

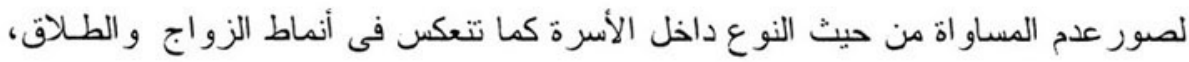

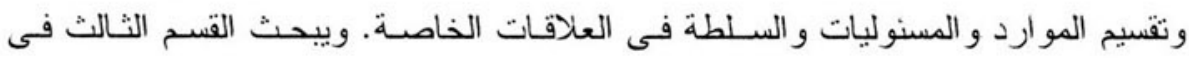

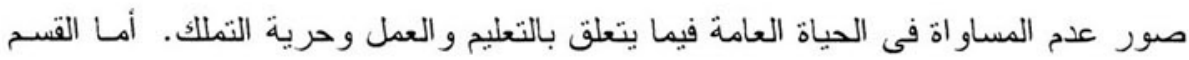

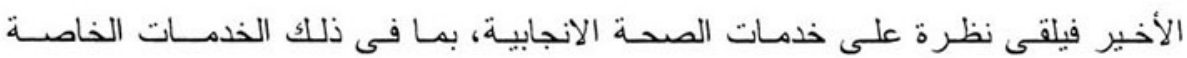
بالاجهاض و الى أى مـدى تستجيب لاحتياجـات النسـاء و الرجـال. وتحدد خاتمــة التقرير أولويات السياسة التى تتصدى لقضايـا المسـاو اة فى النو ع و الصحسة الانجابيـة و الإختيـار الخاص بالانجاب .

\section{المشكلة السكانية و استجابة الحكومة}

تزى الحكومة المصرية أن النمو السريع للسكان هو المعوق الرئيسى للتنميـة

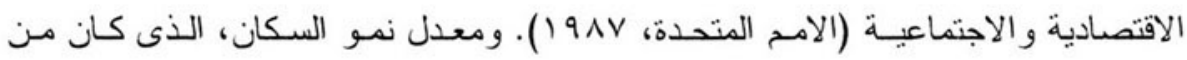

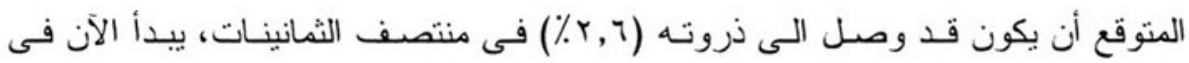

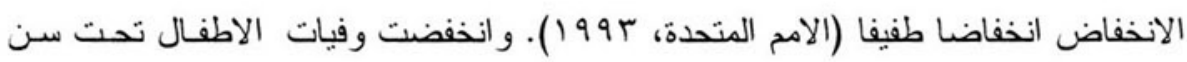

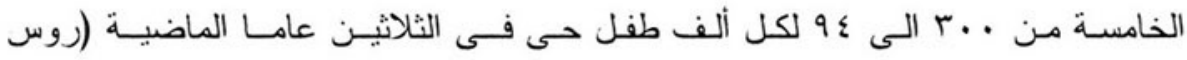

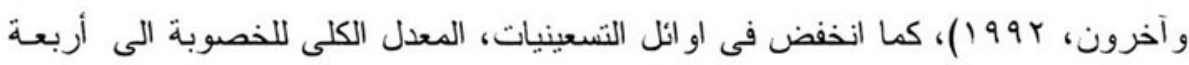

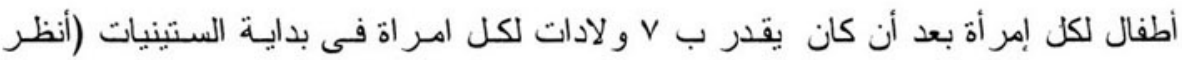

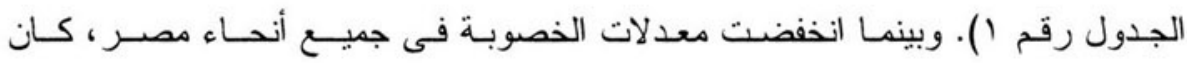
الانخفاض أشد انحدار ا فى المناطق الحضرية فى الوجه البحرى حيث يصل المعدل الكلى 
للخصوبة حاليا الى أقل من r أطفال. وقد بدأ الانخفاض الاخبر فى الخصوبة فى المناطق

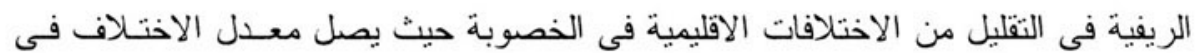
الخصوبة بين المناطق الحضرية في الوجه البحرى و المناطق الريفية فى الوجه القبلى الى لى لئل

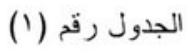

تطور معدلات الخصوبة الكلية

حسب الإقليم

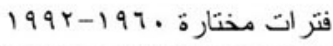

\begin{tabular}{|c|c|c|c|c|c|}
\hline \multicolumn{2}{|c|}{ وجه قبلى } & \multicolumn{2}{|c|}{ وجه بحرى } & \multirow[t]{2}{*}{ مصر } & \multirow[t]{2}{*}{ الفترة } \\
\hline ريف & حضر & ريف & حضر & & \\
\hline V.Ar & $v, \varepsilon r$ & $v, 01$ & $V . \cdot \varepsilon$ & $v . .9$ & $1970-197$. \\
\hline$v .70$ & $7 . \leqslant 9$ & $v, \varepsilon \cdot$ & $0, \varepsilon V$ & $7.0 r$ & $19 v .-1970$ \\
\hline 7,71 & 0.71 & 1.or & $\varepsilon, \varepsilon 7$ & $0,0 r$ & $19 \vee 0-19 v$. \\
\hline T.r & $0, \wedge v$ & $7, \cdots$ & $\varepsilon, r q$ & $0, r v$ & $191 .-19 \vee 0$ \\
\hline 7,10 & $\varepsilon, 1 v$ & $\varepsilon, v r$ & $r, \wedge 1$ & $\{, \leqslant 1$ & $19 \wedge \wedge-19 \wedge 7$ \\
\hline 7,71 & $r, \wedge t$ & $£, \wedge १$ & $r, \leqslant\}$ & $\varepsilon, 1 r$ & $1991-19 \wedge \mathrm{V}$ \\
\hline $0,9 \mathrm{~V}$ & $r, 01$ & $\varepsilon .1$ & $r, \wedge$. & r.9r & $1994-199$. \\
\hline 0,19 & $r, \wedge$. & $r . \leqslant 0$ & r.77 & r.tr & $1990-1995$ \\
\hline
\end{tabular}

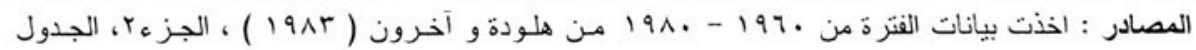

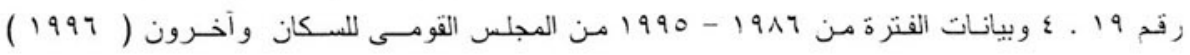

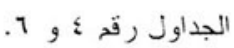

وصاحب الانخفاض فى الخصوبة زيادة فى سـن الزواج الاول وزيـادات مثيرة

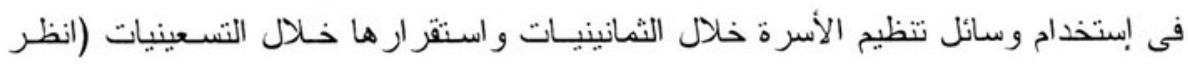
الجدول رقم ؟). ويعزى هذا الاتجاه فى استخدام وسائل نتظيم الأسرة الى انتشار المعرفـة

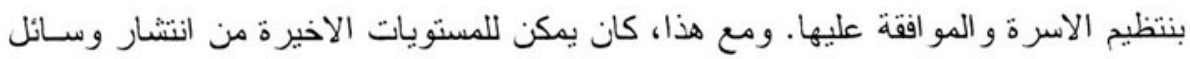

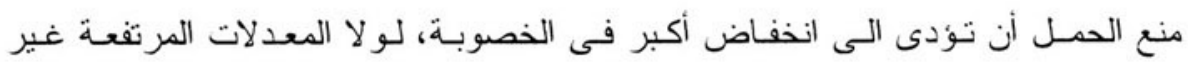

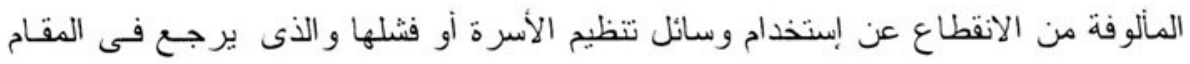

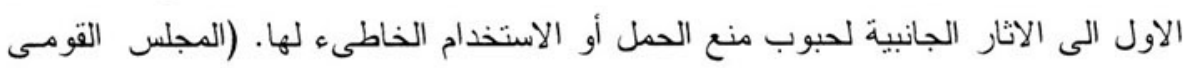

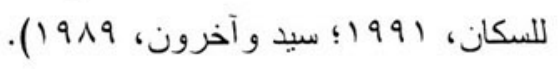




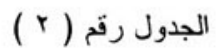

تطور الاستخدام الحالى لوسائل تنظيم الأسرة

199r - 191.

\begin{tabular}{|c|c|c|}
\hline \multicolumn{2}{|c|}{ النسبة المنوية للأزواج المستخدمين } & \multirow[t]{2}{*}{ سنة المسح } \\
\hline أية وسيلة حديثة & أية وسيلة & \\
\hline$r r, \wedge$ & $r \varepsilon, r$ & 191. \\
\hline rA,V & $r \cdot . r$ & $19 \wedge \varepsilon$ \\
\hline$r 0, \varepsilon$ & $r v, \wedge$ & 1911 \\
\hline$\varepsilon \varepsilon, r$ & $\varepsilon \vee, 1$ & 1991 \\
\hline$\leq:, 1$ & $\varepsilon \vee, 1$ & 199r \\
\hline$\varepsilon 0,0$ & $\leqslant \vee, 9$ & 1990 \\
\hline
\end{tabular}

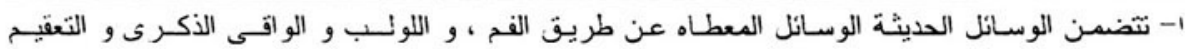

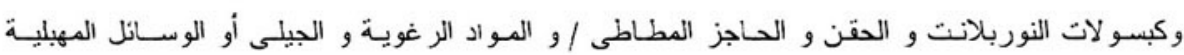

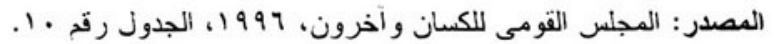

و اذا وضعت أولويات النساء المصريات فيما يخص الحمل موضع الثتفيـذ، فانهـا تفترض أن يكون الانخفاض الاكبر فى معدلات الذصوبة امسرا امرجحـا. وكمـا اشسبر فى المسح الديموجر افى و الصحى المصرى فى عام 99 ا ا، فإن منوسط حجم الاسرة الامثل للدى النساء اللاتى سبق لهن الزواج كان 9،r طفلا. ومع هذا فان نسـبة . r \% مـ النسـاء المتزوجات اللاتى بر غبن فى المباعدة بين الولادات أو وضع حـ للحمل لاتمارنسن الان تنظيح الاسرة (الزناتى و أخرون، 1999 ).

وتعتبر مصر أول بلد عربي يواجه قضابيا السكان على مستوى السياسـة القومبـة

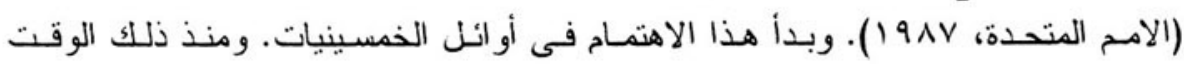
المبكر ، ركزت السياسة السكانية على نوفير خدمات تتظيم الاسرة، فى البداية عـن طريـق القطـاع الخـاص، ثـم عن طريـق القطـاع العـام. وفـى السـبعينيات، اتسـع نطـاق السياسـة السكانية وتم الاعتر اف بأن نمو السكان يتـأثر بالتتميـة الاجتماعبـة و الاقتصاديـة، لـذا فـان استخدام الخصائص الاقتصادية - الاجتماعية بـات متضمنـا باعتبـار هـز عا مـن السياسـة السكانية الشاملة (سيد، 9199 19) والنطاق الحالى للسياسة السكانية بشنمل على: (1) نتظيـ الاسـرة (Y) رفاهيـة الام و الطفل (Y) المـر أة و الثتعبـة (ع) المعلومـات الخاصـة بالسـكان 
و النعليم و الاتصال (0) العمل و التوظف (†) الثباب (v) البيئة (^) التعليم (9) و استخدام الارض ( المجلس القومى للسكان، (99 (1).

ويعكس هذا النطاق الموسع إعادة نعريف المشكلة السكانية فى مصر ـ فقد سيطر

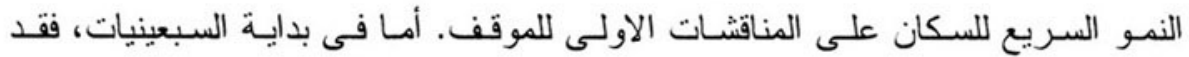

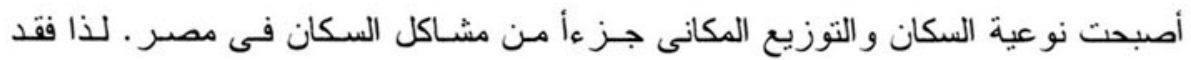
ركزت السياسات السكانية على أهمية نوفير خدمات تتظيم الاسرة فضلا عن تشجيع التغير الاقتصادى و الاجتماعى الذى يمكن أن يؤثر فى الطلب على خدمات نتظيم الاسـرة (انظر

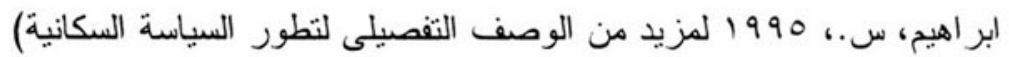

امـا فيما يخص الأمسور المتعلقة بالانجـاب، فـان سياسـة مصر السكانية فضلت

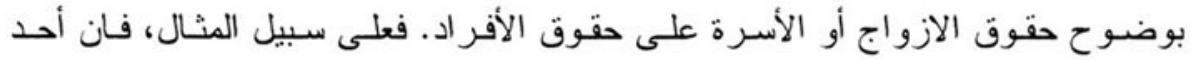
المبادي الرئيسية الموجهة للسياسة القومية للسكان لعـام 1917 هو الاعتر اف بحق كل العل

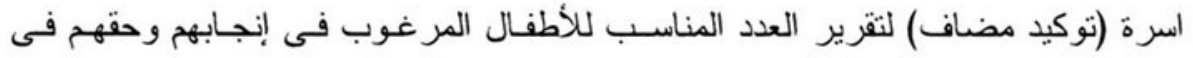

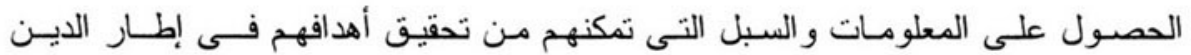

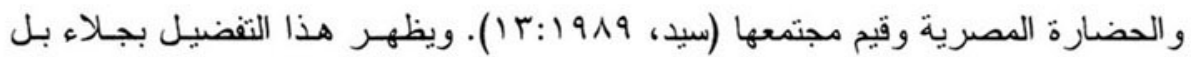
ويتم التأكيد عليه مـن خـلال الاشـارة الـى القيم الدينيـة و المجتمعيـة. و الموقف الاسـلامى المفضل تجاه القر ار الخاص بتتظيم الأسرة هو أن مثل هذا القرار يستلزم الاتفاق المتبـادل بين الزوجين (عمران، ب99 (1). إن تأكيد السياسة السكانية على حقوق الأسرة أو الأزواج

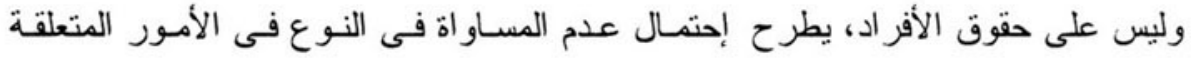

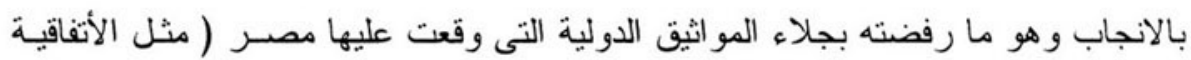

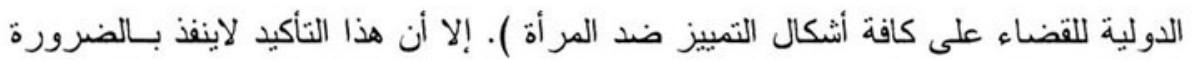

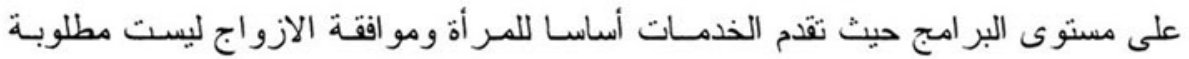

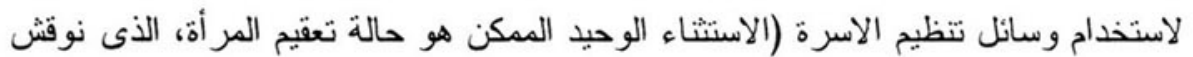

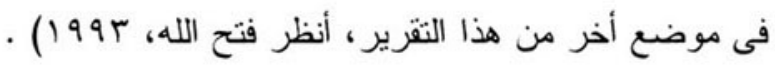

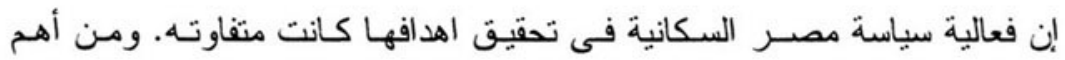

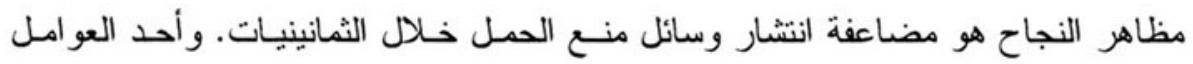

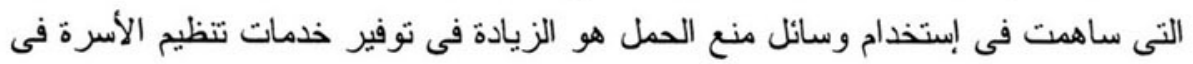


مصر • ويعرف معظم النسـاء (r9\%) و الرجـال (r9\%) مـن أين يحصلون على خدمـات

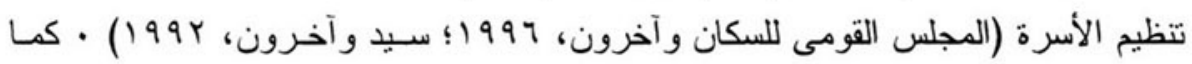

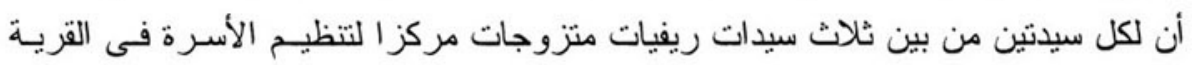

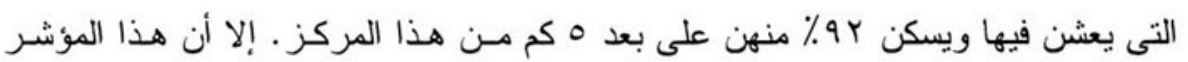

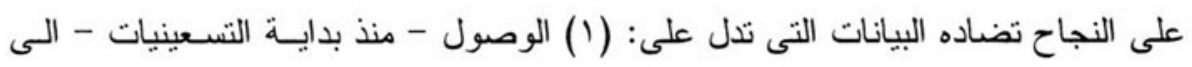

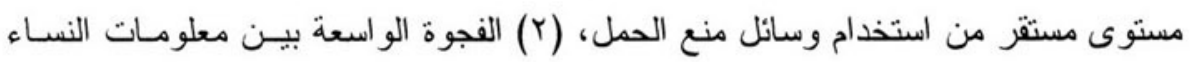

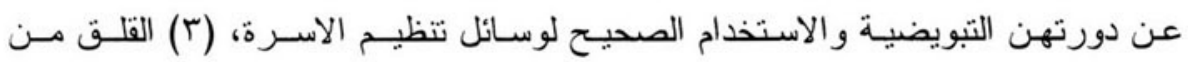

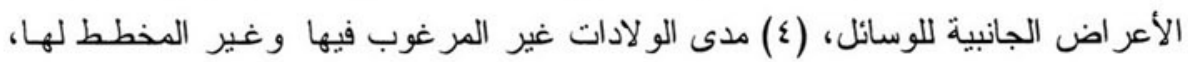

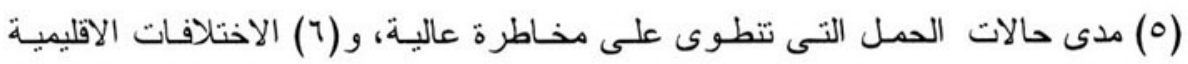

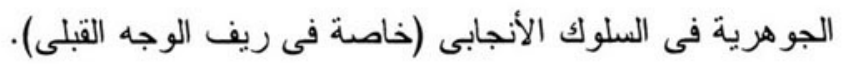

ويكمن المؤشر الآخر على نجاح سياسة مصر السكانبة فى التحسن فى صحسة

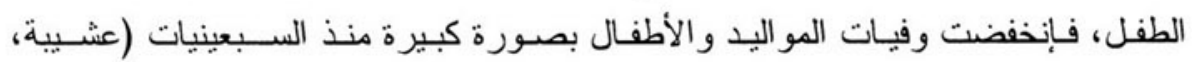

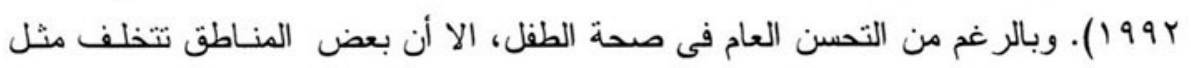

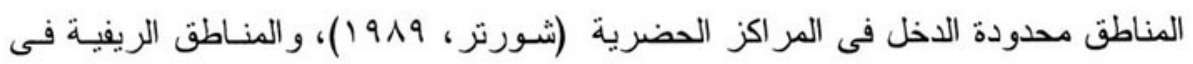

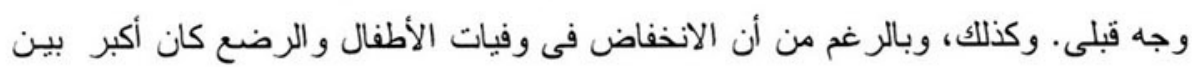

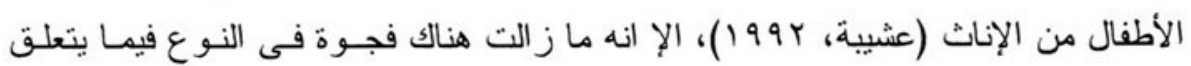

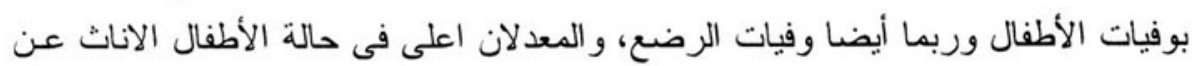

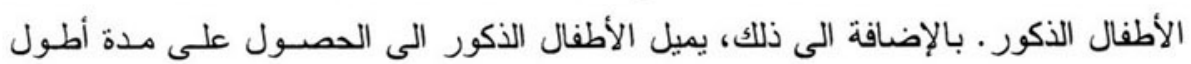

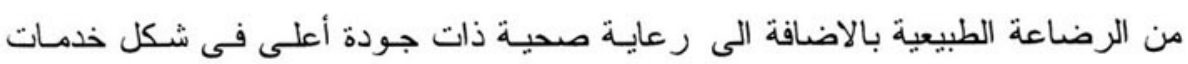

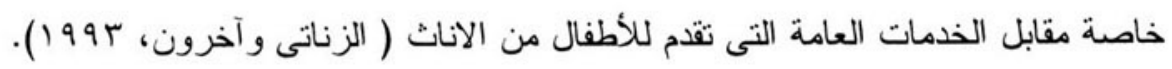

وأصبحت صحسة الأم موضـع نركيز نشط للسياسـة السكانية. و أنشـأت مصـر المجلس القومسى للأمومـة و الطفولـة مـن أجلـ توفير الظـروف الأقتصاديـة والاجتماعيـة

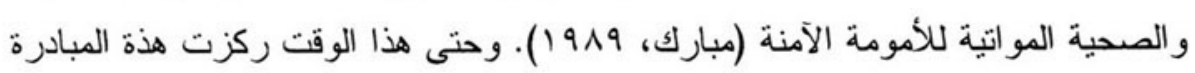

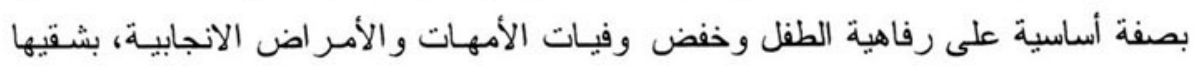

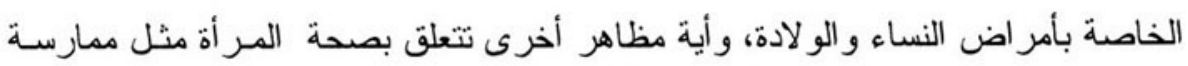

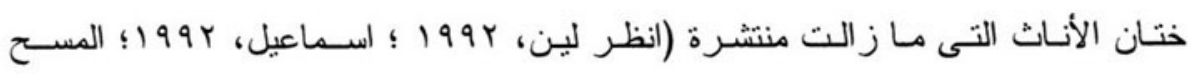

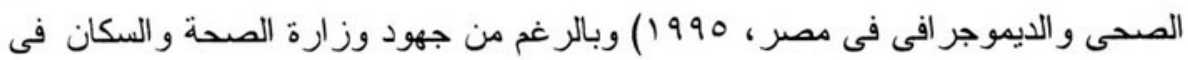


القضاء على هذه الممارسة، إلا إن القابلات التقليديات وبعض الاطباء يجرين هذه العملية

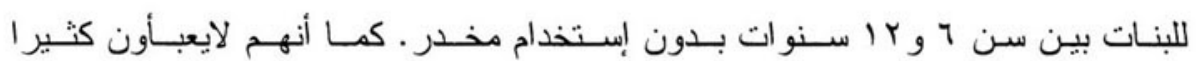

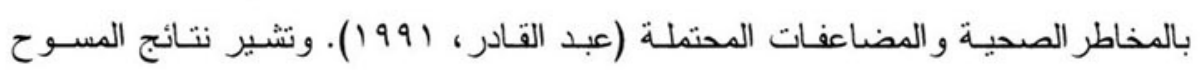
القومية إلى أن أكثر من و٪ من النساء المصريات مخنتات، وأن لهذه الممارسـة جذور عميقة فى التقاليد المصرية.

و استخدمت مصر أيضا القانون كأداة للسياسة السكانية. ومن أمثلــة ذلك القانون

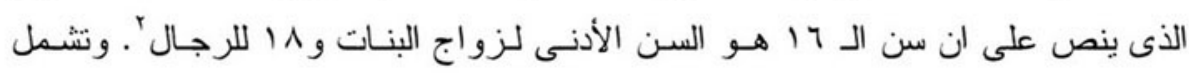

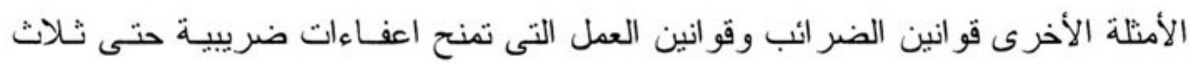

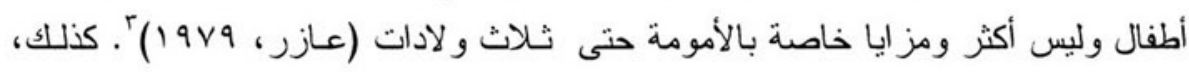

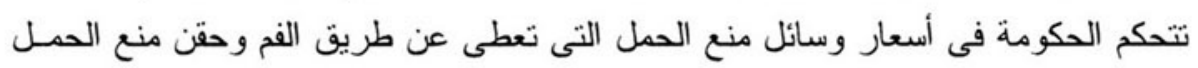

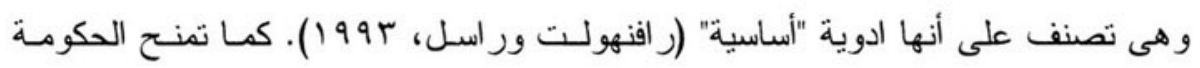

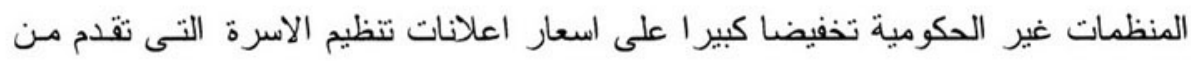

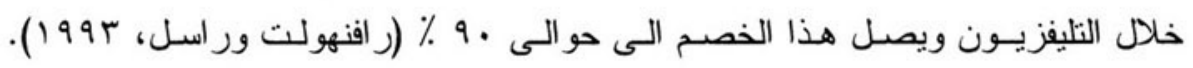

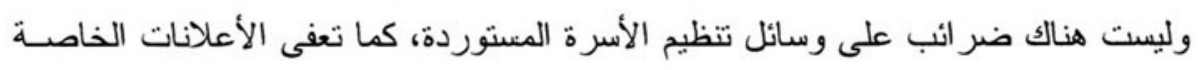

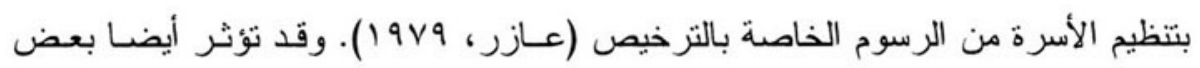

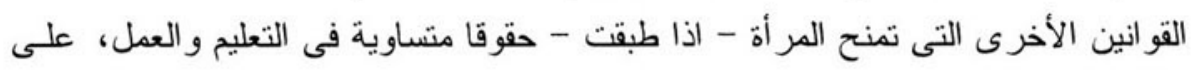

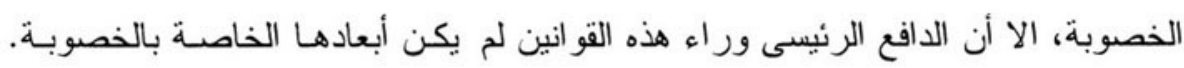

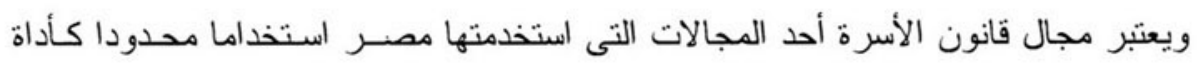

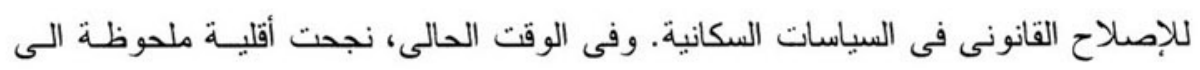

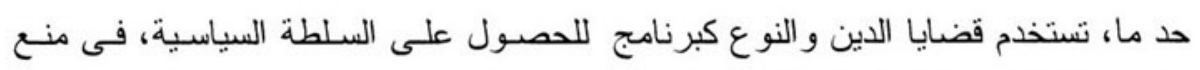

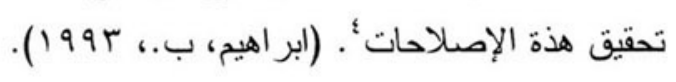

\section{عدم المساواة فى النوع داخل الأسرة}

تعتبر الأسـرة أكثر المؤسسـات الاجتماعيـة أهميـة مـن حيث القيمة في مصـر

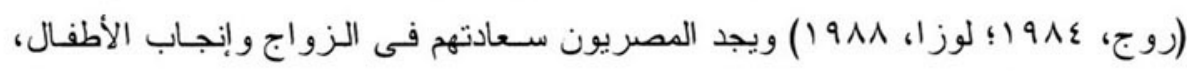

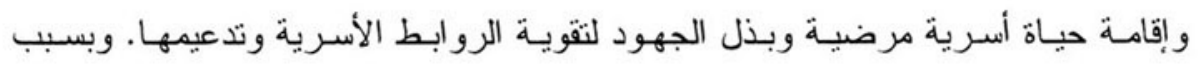

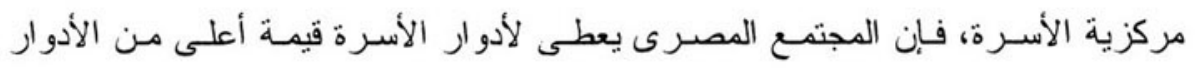

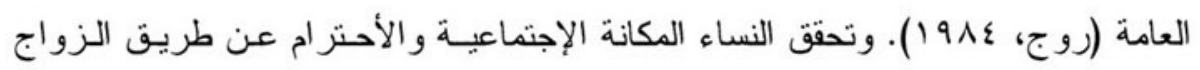


من خلال أدو ارهن كأمهات وزوجات. وتقيس معظم السيدات المصريات، بصـرف النظر

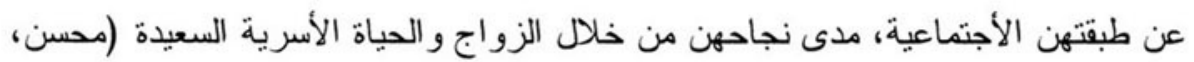

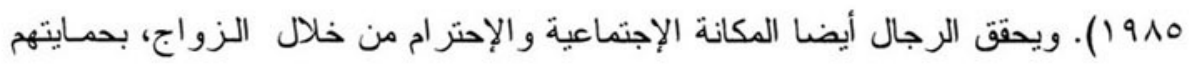

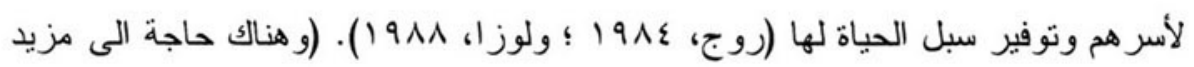
من البحث لاستكشاف مصادر المكانة والاحتر ام بين الرجال المصريين).

وبالر غم من قوة الأسرة و القيم الإجتماعية الرفيعة للعلاقة التبادلية فى الزواج فى التى التي

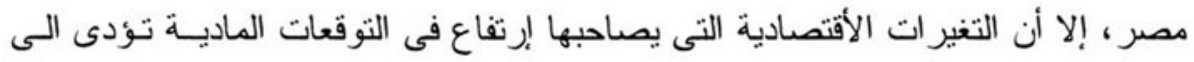

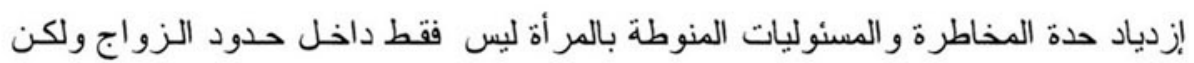
أيضا خارجه. إن تكامل الأدوار داخل الأسرة الذى كان بنظر إليه تقليديا على إنه مصدـدر

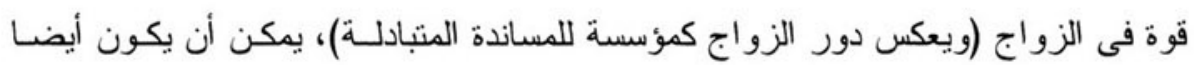

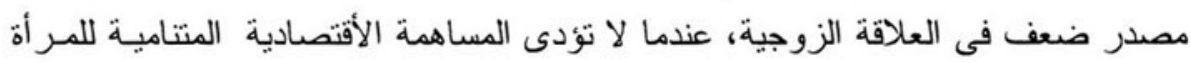

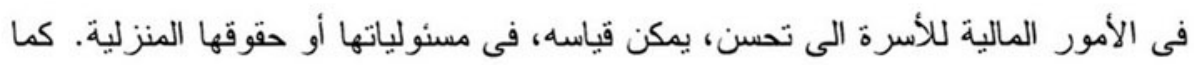

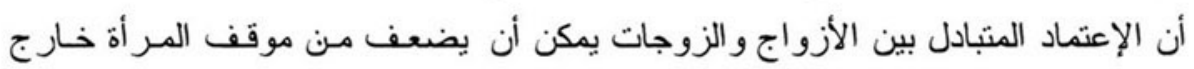

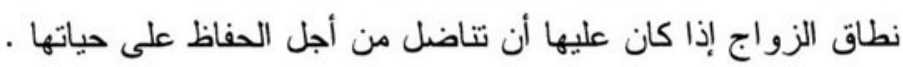

ونحاول فى هذا القسم استكشاف حقوق ومسئوليات الرجال و النساء داخل الزواج المصرى التقليدى موضحين مصادر قوته ونقاط الضعف المحتملة، ثُ ننظر الى ما يعنيه

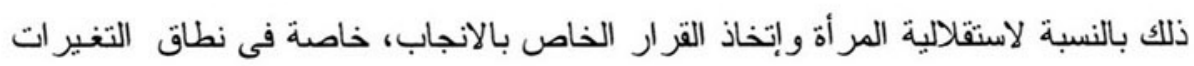

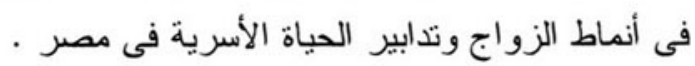

$$
\text { الجو انب القانونية و العرفية للزواج }
$$

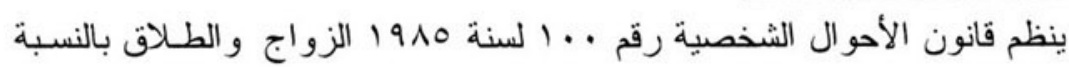

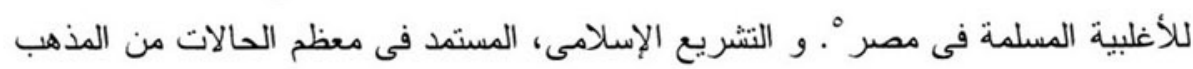

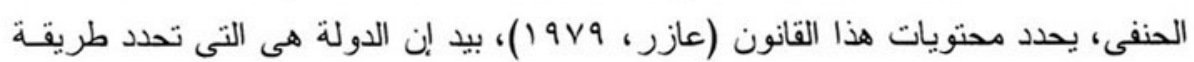

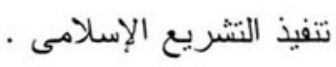

يتم التعاقد على الزواج فى الاسـلام استتادا الـى مو افقـة الطرفين فـى حضـور

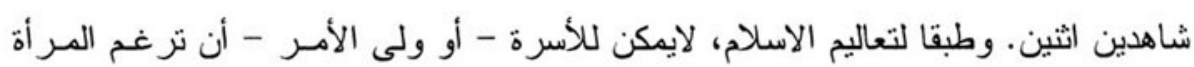

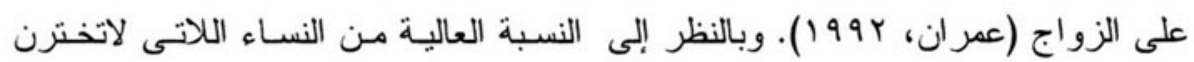


أزواجهن، بل يختاره لهن شخص آخر ، فإن الحصول على مو افقة المر أة يعتبر من الأمور

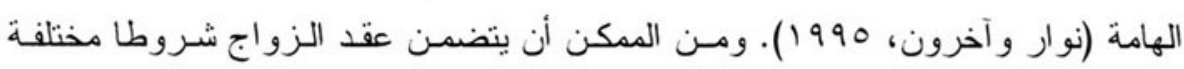

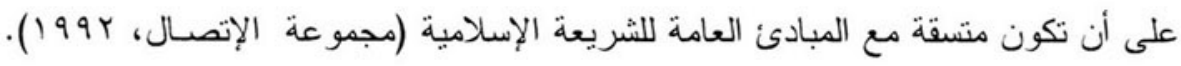

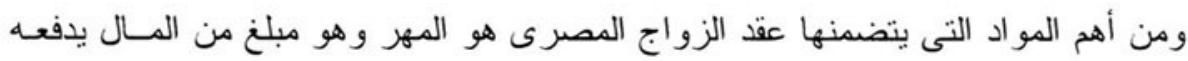

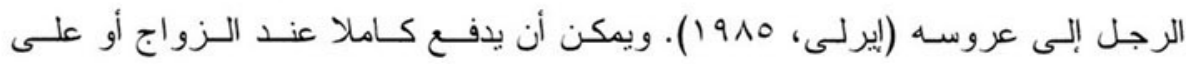

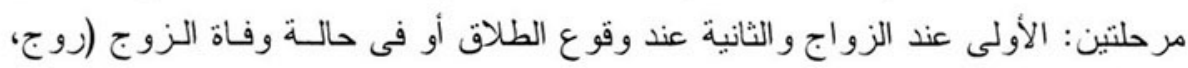

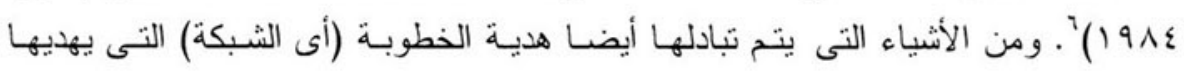

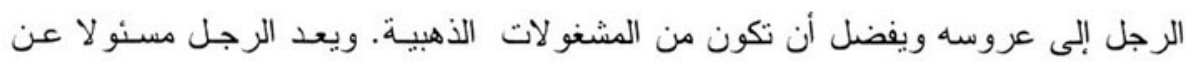

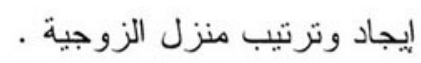

و المسئولية المالية للعروس وأسرتها أكثر محدودية. و المطلوب منهم عادة توفير

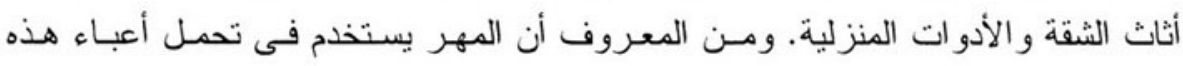

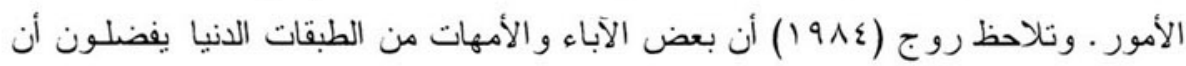

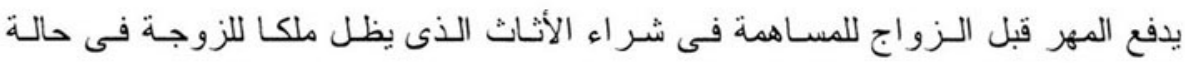

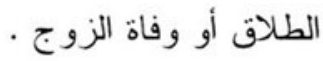

وتدرج الموجودات التى يأنى بها كل من الطرفين في قائهـة يتم غالبـا توثيقها

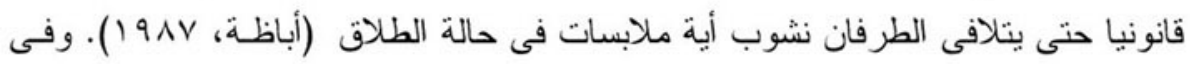

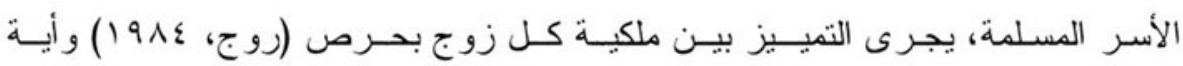

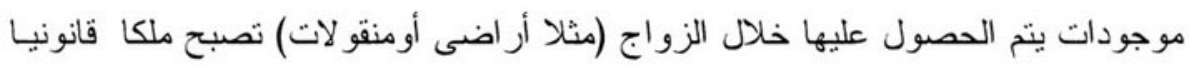

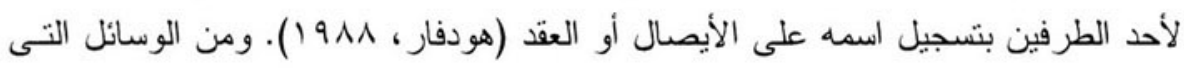

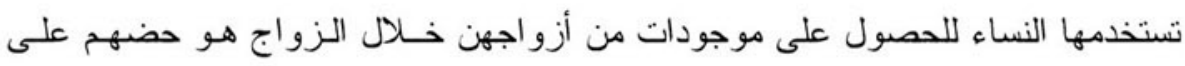

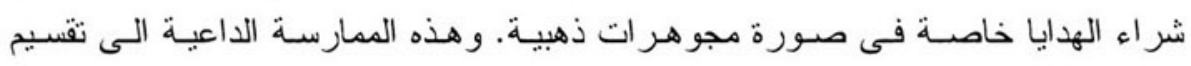

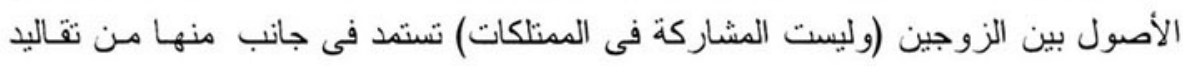

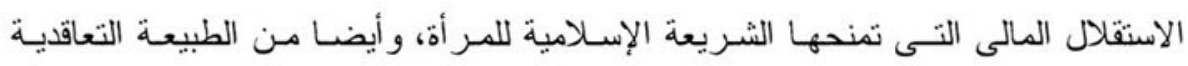

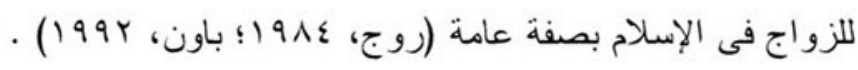

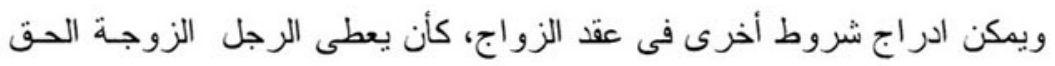

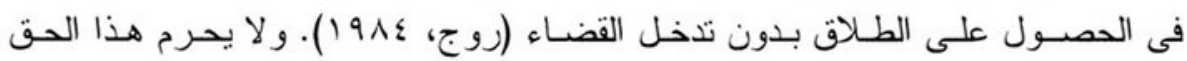


الرجل من حقه فى الطلاق من طرف و احد، كما يعتقد الكثير من المصريين. كذلك بمكن

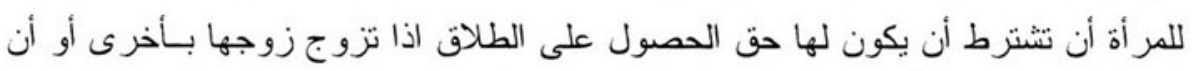

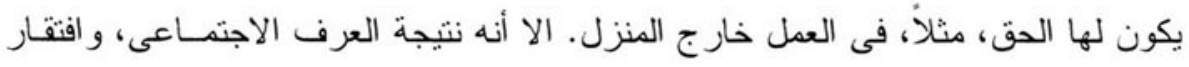

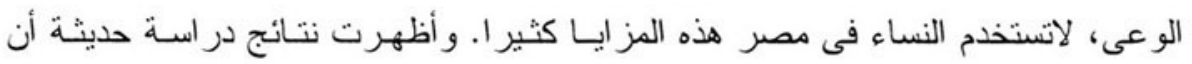

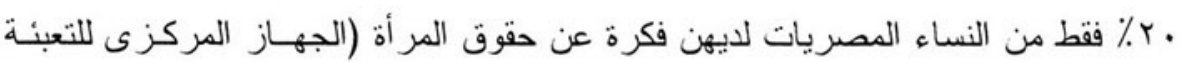

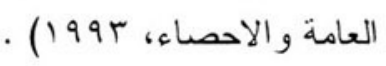

وقد أوضحت در اسة مسحية أنه بالر غم من معرفة % من النسـاء بحقهن فى

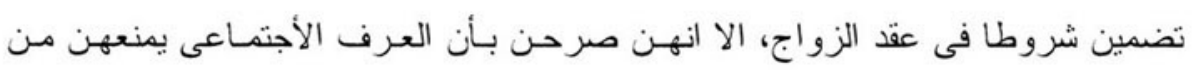

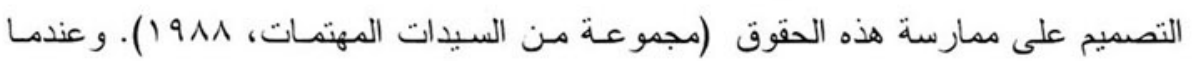

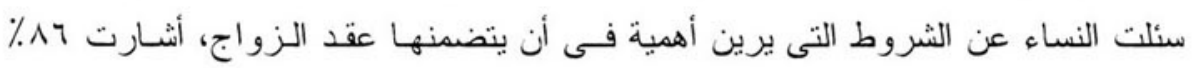

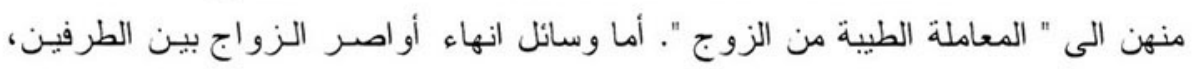

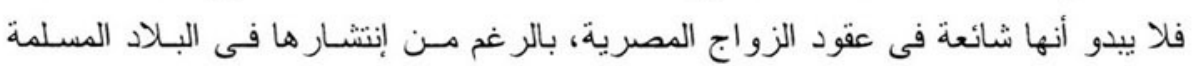

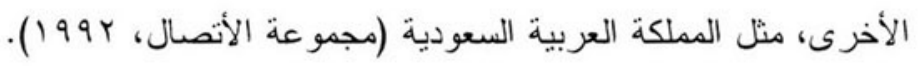

و هناك اعنقاد واسع الإنتشار بأن لا يجب افساد مناسبة الزواج بمناقشة المشاكل

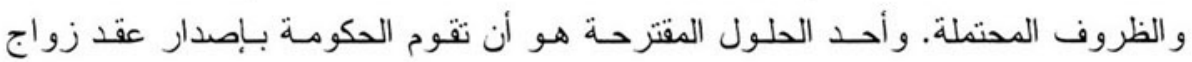
قباسى يتضمن الكثير مـن هذه الشروط الأساسية كشروط اختياريـة ويكون ذلك كفيـلا

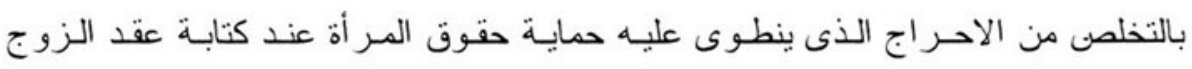

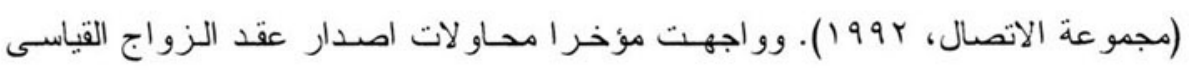

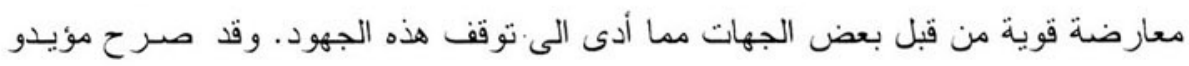

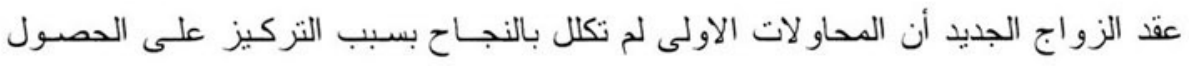

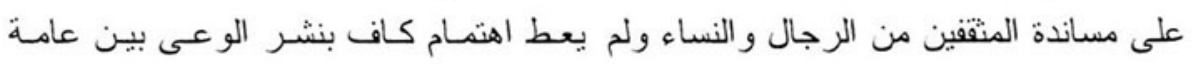
النساء عن حقوقهن فى نطاق الزواج.

ومـن المحتمل أن تتتهى الزيجـات المصريـة نتيجـة للوفـاة ( إ٪ مـن نهايـات

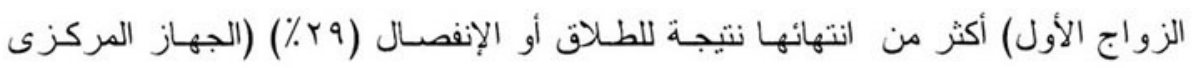

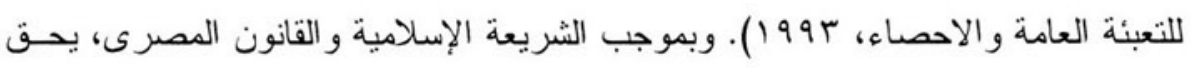

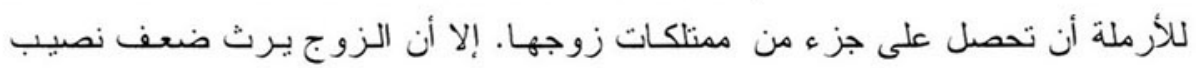




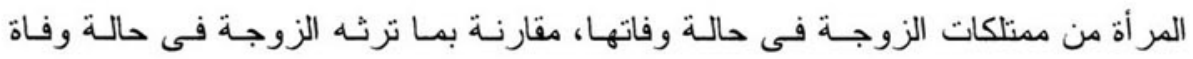

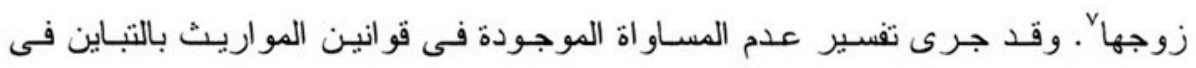

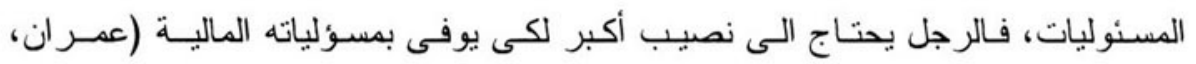

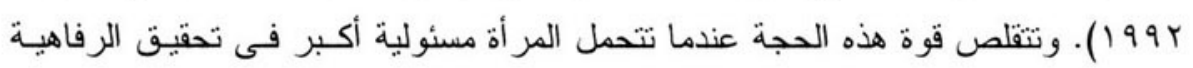

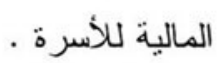

و عموما، فإن الأرملة تحصل على \&/1 الممنلكات فى حالة عـدم وجـود أطفـال،

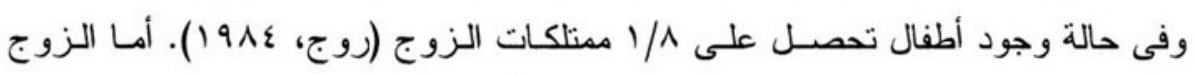

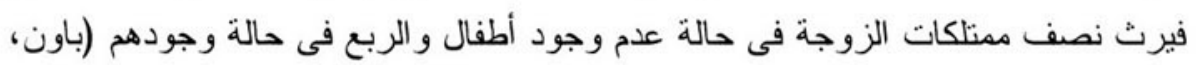

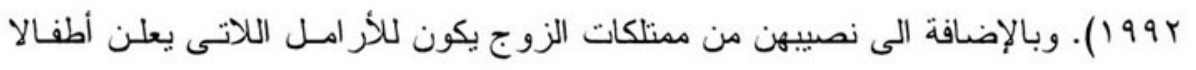

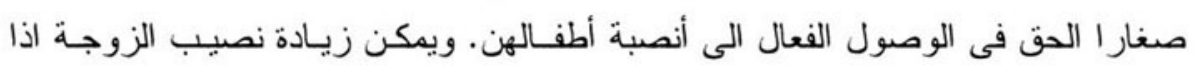

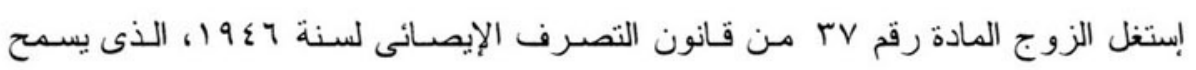

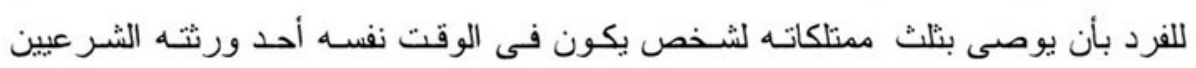

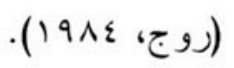

وليس معروفأ الى أى مدى تحصل المر أة فعليا على حقها الثر عى فى الأرث.

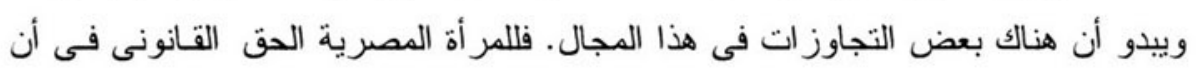

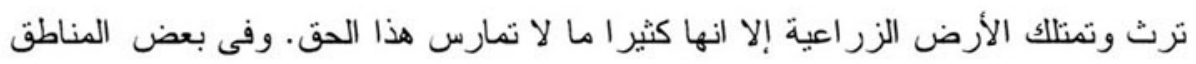

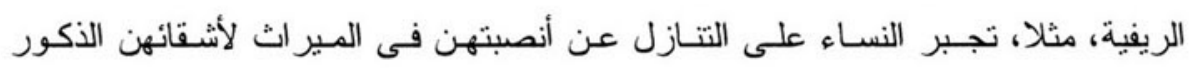

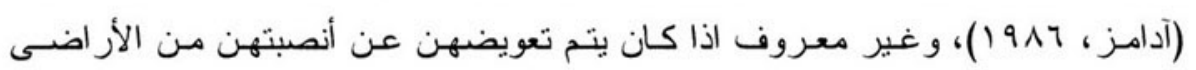
الزر اعية.

وللأرملة الحق أيضا فى الحصول على معاش زوجها. وطبقـا لقانون التأمينـات

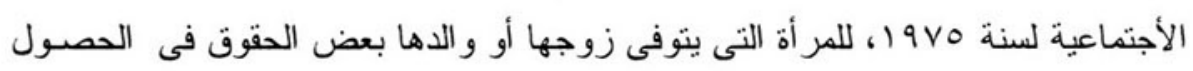

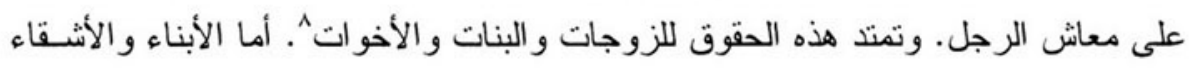
فهم غير مؤهلين للحصول عليها.

وتعتبر الوصاية على الأبناء مـن القضايـا التى تو اجـه الأر امـلـ وطبقـا للقانون

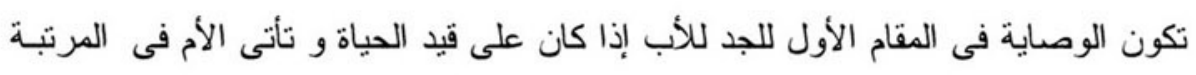


الثانية بعده ، فإذا كان منوفيا تثثبت الوصاية لـلأم . أيضـا تثبت لـلأم إذا كـان الجد لـلأب

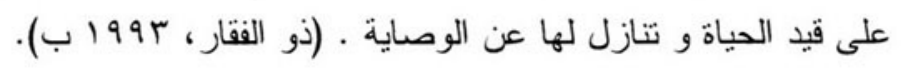

و الطلاق من الأمور المسموح بها فى الأسلام ما لم يكن هناك بديـلا آخر ولكنـهـ

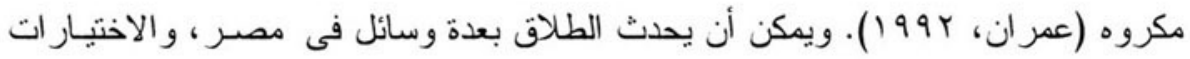

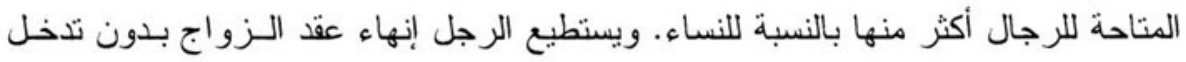

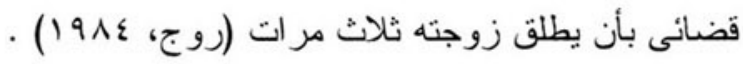

وكما أشير سابقا، يجوز للمر أة أيضا أن تطلق نفسها بدون اللجـوء الىى القضــاء

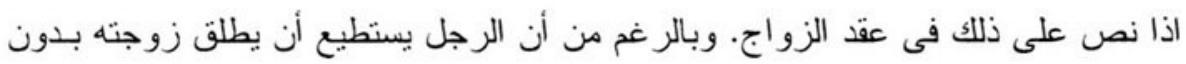

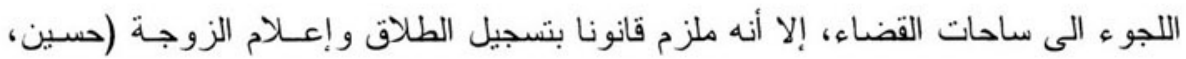

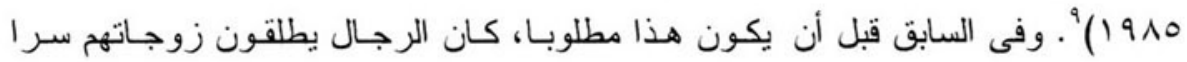

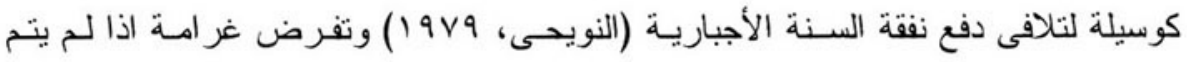

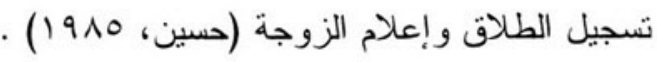

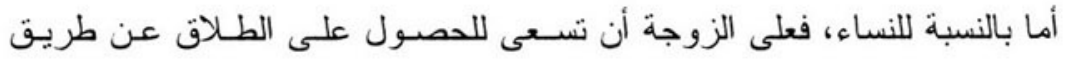

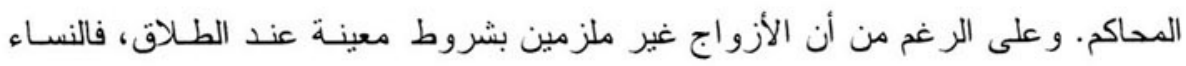

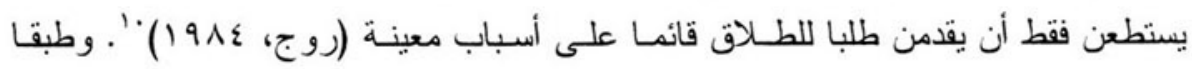

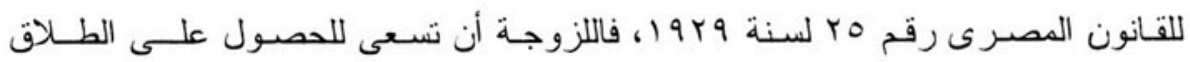

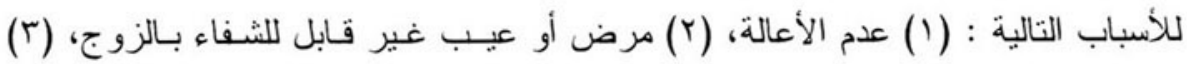

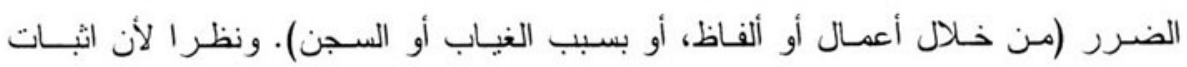

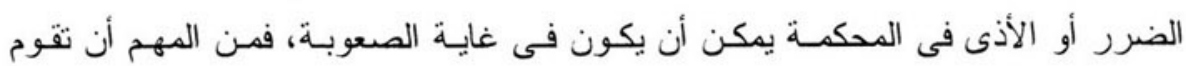

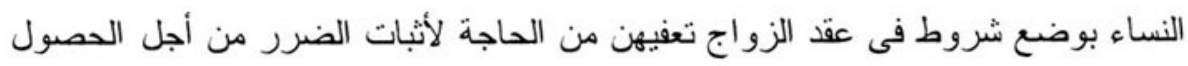

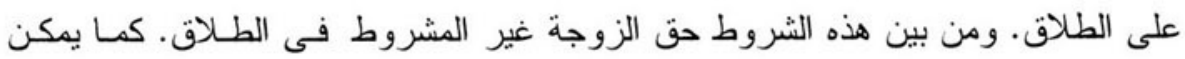

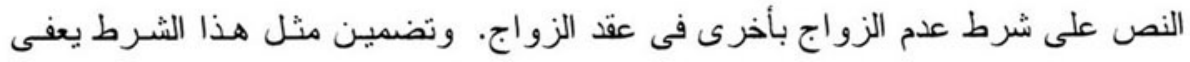

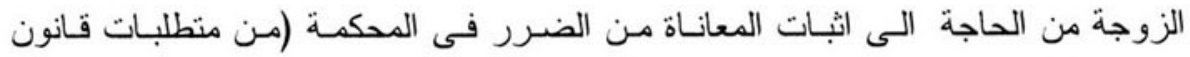

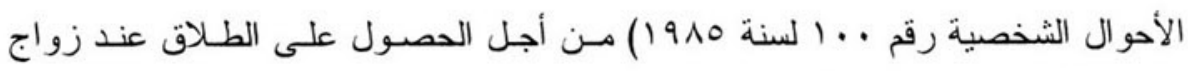
الرجل بأخرى (مجموعة الأتصال، و 1991) . 
و هناك وسيلتان اضافيتان للحصول على الطلاق : الأولى بـالتراضى المتبـادل

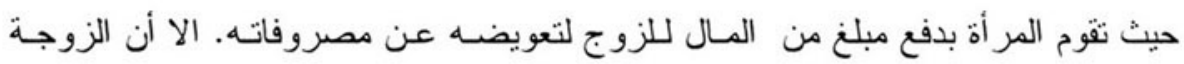

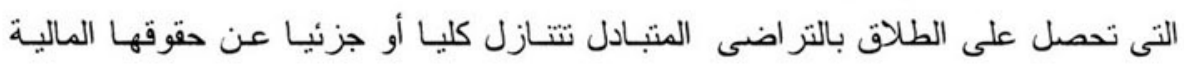

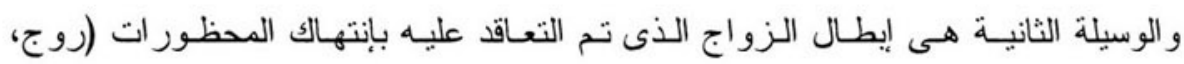
. (191

وبسبب اختلاف الوسائل النى يحصل من خلالها الرجال و النسـاء على الطـلاق،

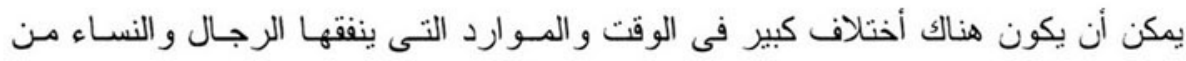

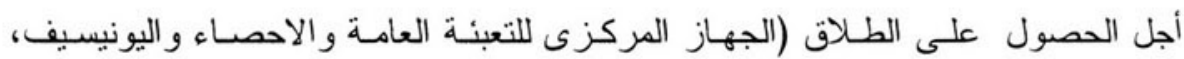

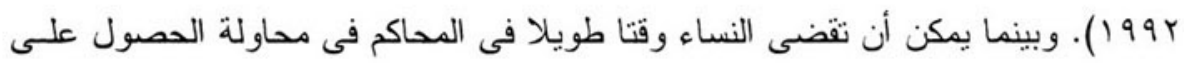

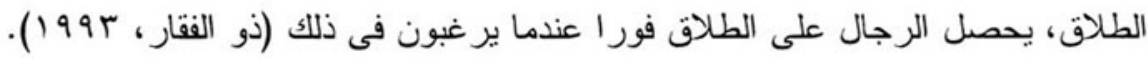

وتتضمن الحقوق القانونية للمر أة المطلقة ما يأتى: ( () حضانة الأطفال حتى سن

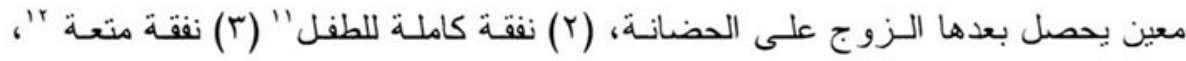

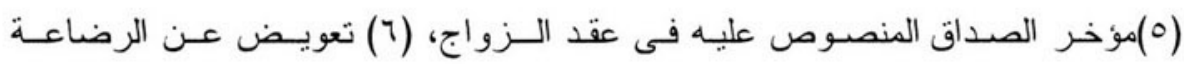

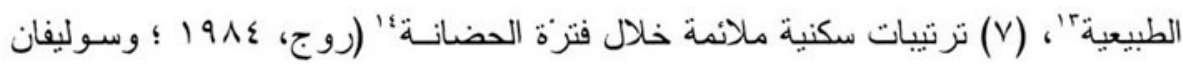

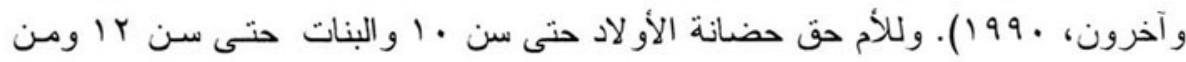

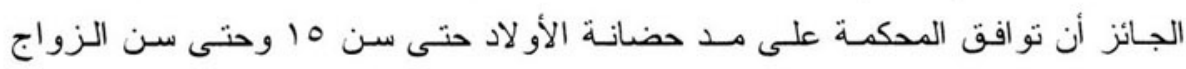

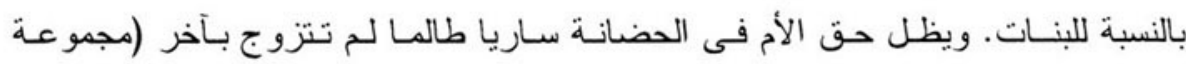

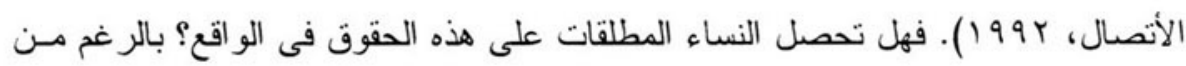

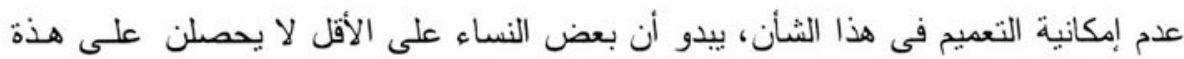

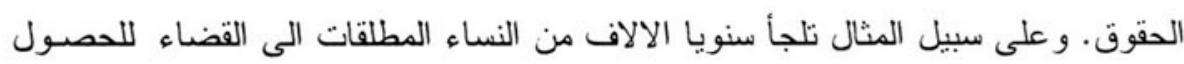

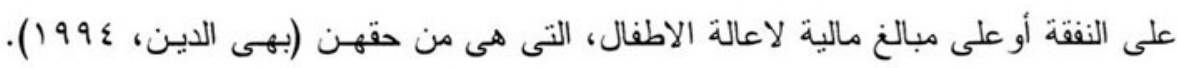

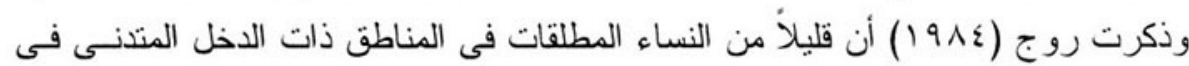

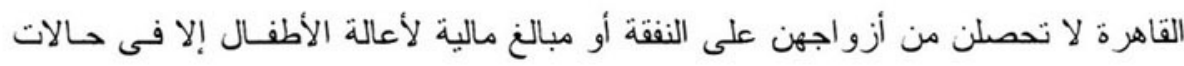

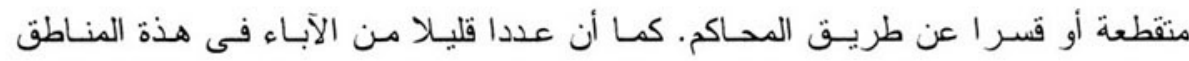

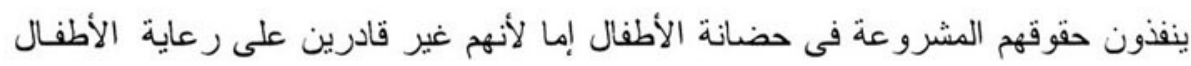

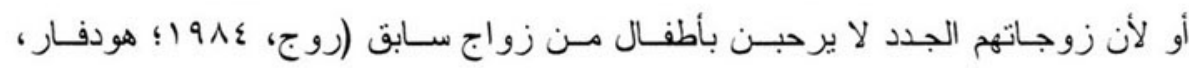

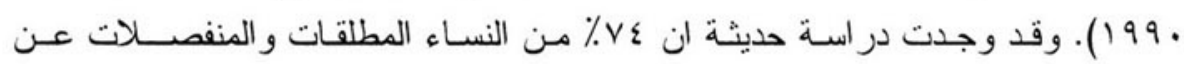


أزو اجهن ذكرن أنهن لا يحصلن على أيـة إعالة ماليـة من أزواجهن السبابقن (الجهاز

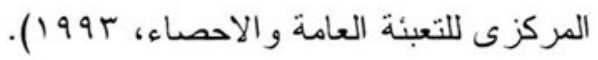

ومع زيادة الحر الك الجغر افى للرجال، أصبح جمع مبالغ الأعالة الماليــة للأطفال

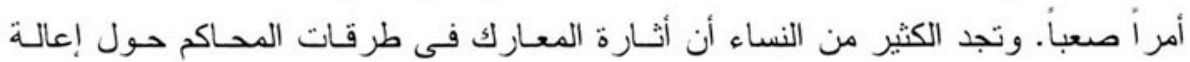

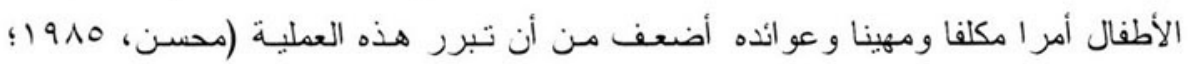

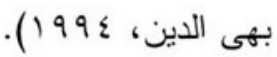

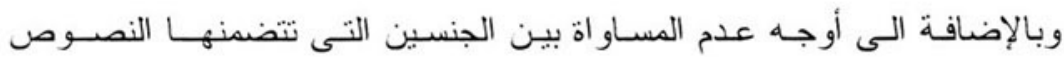

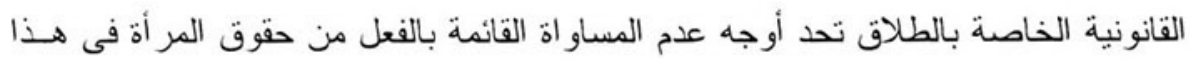

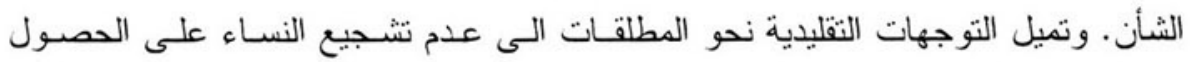

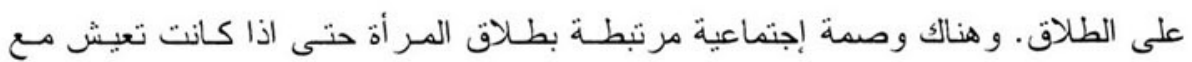

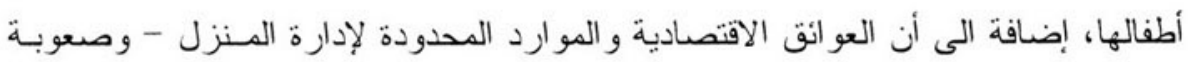

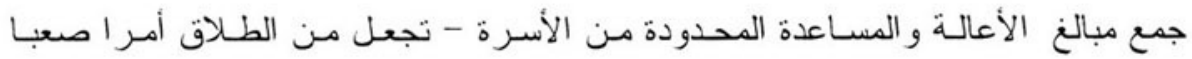

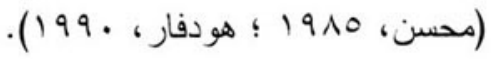

\section{أنماط الزواج وتدابير الحياة الأسرية}

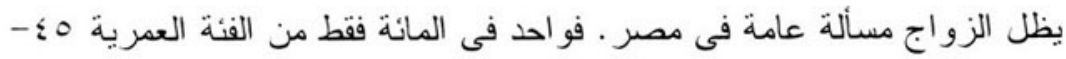

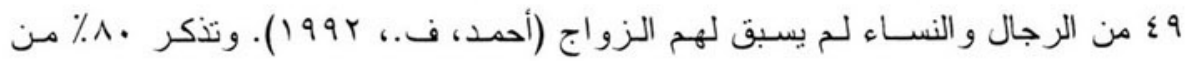

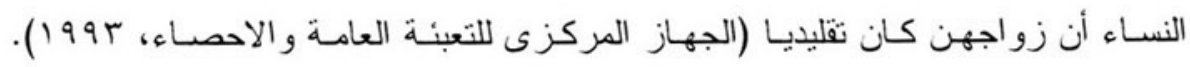

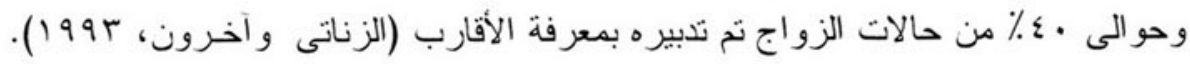

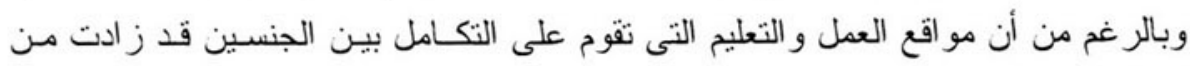

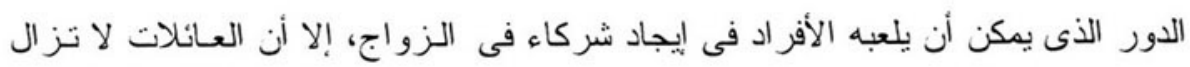

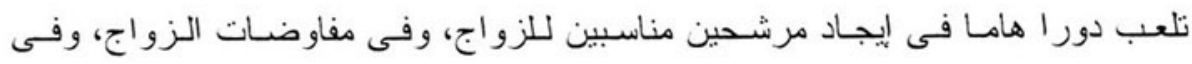

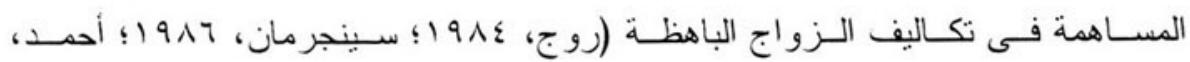

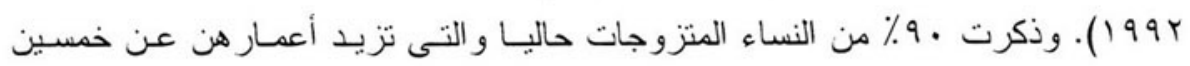

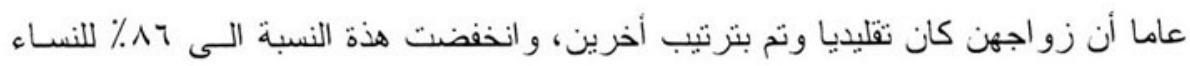

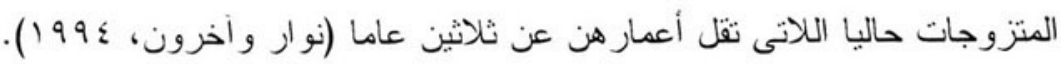


وأرتفع السن الوسيط عند الزواج الأول للنساء اللاتى نتز اوح أعمار هن بيـن 0؛

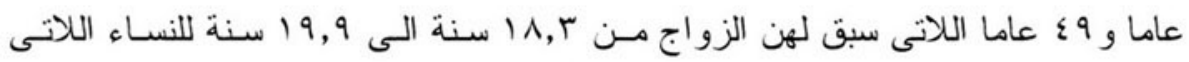

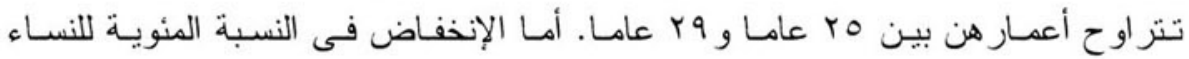

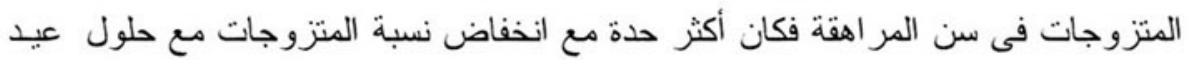

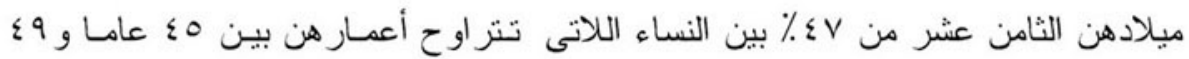

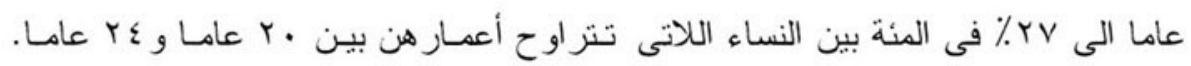

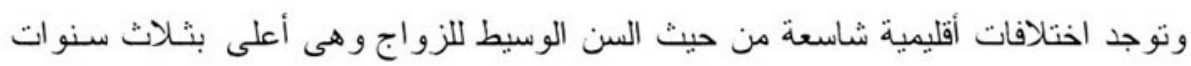

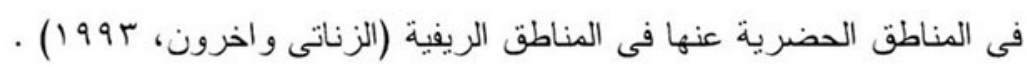

وتقضى النساء فى مصر أكثر من •٪\% من سنو اتهن الأنجابية وهن متزوجـات.

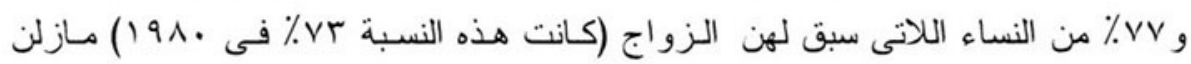

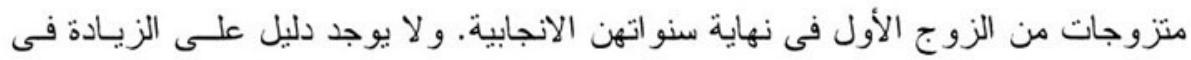

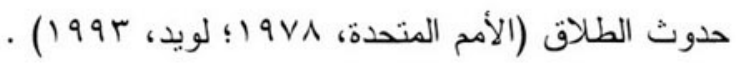

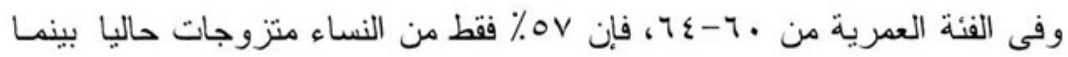

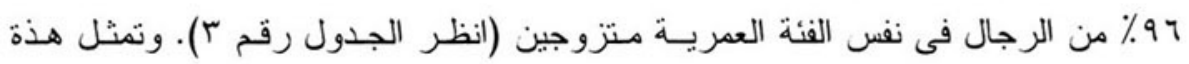

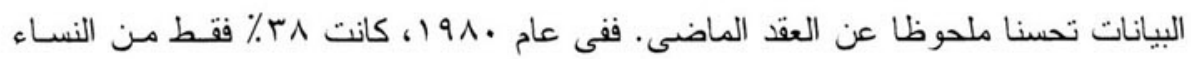

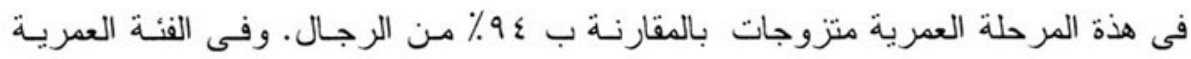

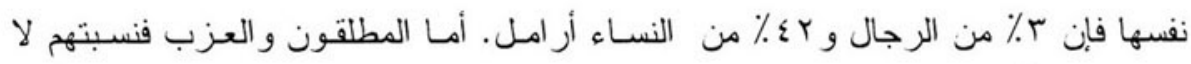

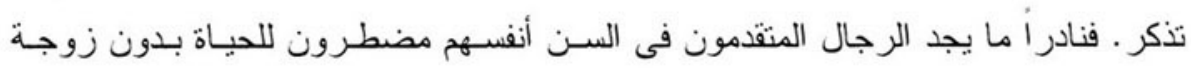

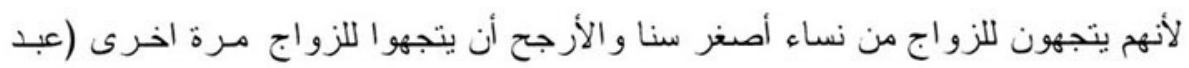

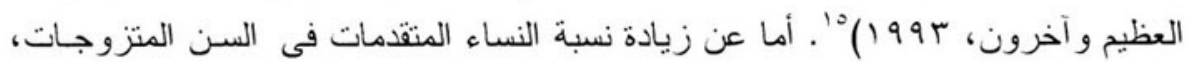

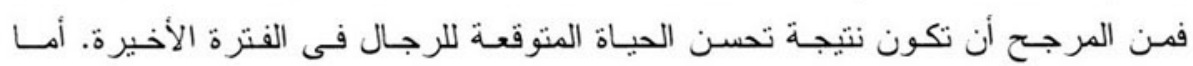
اتجاهات الزواج مرة أخرى بين الأر امل المتقدمين فى السن فهى ليست معروفة. 


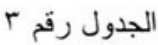

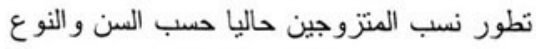

$1991,19 \wedge$.

\begin{tabular}{|c|c|c|c|c|}
\hline \multicolumn{2}{|c|}{ الذكور ( \% ) } & \multicolumn{2}{|c|}{ الإحاث ( \% ) } & \multirow[t]{2}{*}{ السن } \\
\hline 1991 & 191. & 1991 & 191. & \\
\hline$\cdot, 9$ & $r, r$ & Ir,. & $r, v$ & $19-10$ \\
\hline $1 \leqslant, \varepsilon$ & $r \cdot, \varepsilon$ & $00, r$ & Tr,r & $r \varepsilon-r$. \\
\hline$\varepsilon q, 0$ & $07, r$ & $\wedge r, 0$ & $\wedge r, l$ & $r_{q}-r_{0}$ \\
\hline Ar,T & sr,v & $9 ., 1$ & $9 ., 0$ & $r \varepsilon-r$. \\
\hline $9 \leqslant, 0$ & $9 r, \wedge$ & 91,1 & $\wedge \vee, q$ & $r_{q}-r_{0}$ \\
\hline $9 \wedge, r$ & $97, V$ & $\wedge \varepsilon, \wedge$ & $\wedge \varepsilon, 1$ & $\varepsilon \varepsilon-\varepsilon$ \\
\hline $9 \wedge, r$ & qv, r & $\wedge r, r$ & $\vee \wedge, 9$ & $\varepsilon q-\varepsilon 0$ \\
\hline $9 \wedge, \varepsilon$ & $9 \varepsilon, 9$ & V7,. & $77, r$ & $0 \leqslant-0$. \\
\hline १४,. & $97, r$ & $7 \wedge, 0$ & ov,r & $09-00$ \\
\hline 90,1 & $9 r, 0$ & $07, V$ & $r v, \wedge$ & $7 \varepsilon-1$. \\
\hline 91,1 & ᄉт,० & $r \varepsilon, r$ & 19,0 & ه 1 فأكثر \\
\hline
\end{tabular}

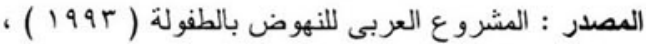

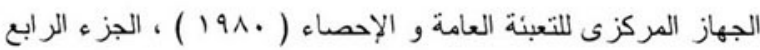

وبالر غم من جواز تعدد الزوجات" '، إلا أن ممارسة هذة الظـاهرة محدودة فى مصر بل إنها فى إنخفاض \ا فان نسبة تقل قليلا عن ع ٪ من النساء المنزوجات حاليا تحت سن 9 ؟ كن مرنبطات بعلاقات زوجية نتسم بتعدد الزوجات (المشرو ع العربسى للنهوض

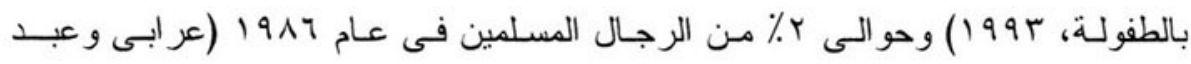
الفتاح، (99 (1). وبالر غم من ان ظاهرة تعدد الزوجات محدودة فهـاك جدل بـأن مجرد وجود حق الرجل فى الزواج من أخرى بـدون شـروط بكون لـه أنـر نفسى ضـار على النساء خاصة بين الطبقات ذات الدخل الأدنى (حسين، 9 ( ) ).

و غالبية النساء المرتبطات بعلاقات زوجية نتسم بتعدد الزوجات غبر متعلمات أو

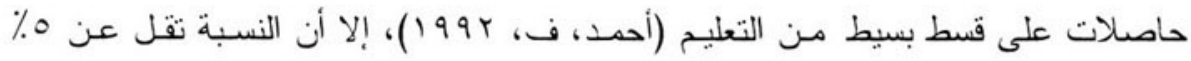
حتى بالنسبة للنساء الحاصلات على أقل قسط من التعليم المرتبطات بمثل هذذة العلاقات الزوجية (عبد العظيم و آخرون، ب99 (1)). 
أن الرجال مسئولين تقليديا عن ثوفير الاحتياجات المالية لأسر هم وحماية الأسرة

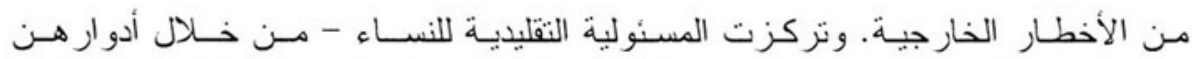

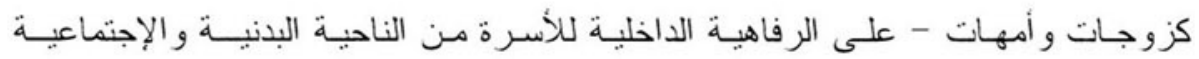

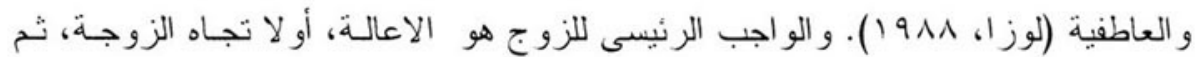

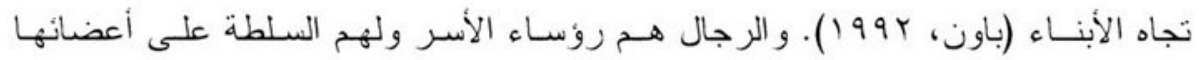
الأخر بن. و للر جال الحق القانونى فى طلب الطاعة من الزوجات. أما الزوجة فمن مهامهـ

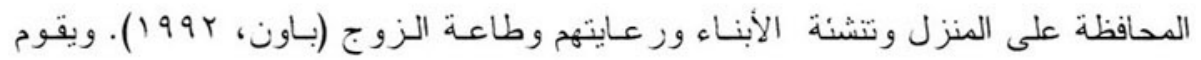

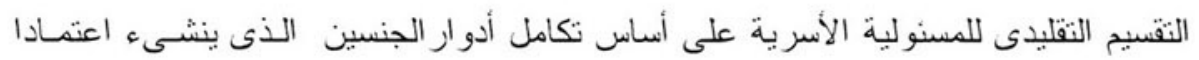

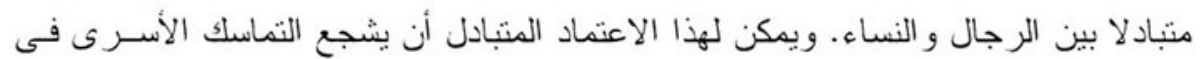

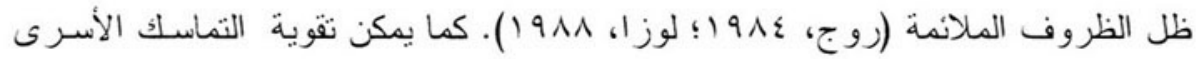

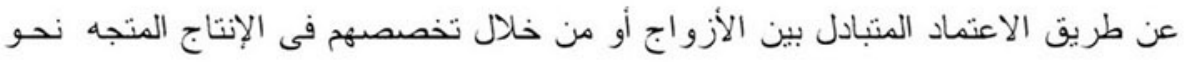

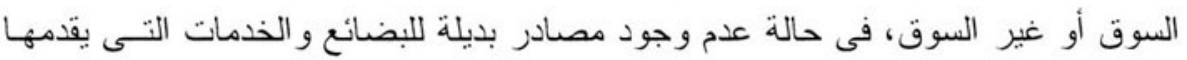

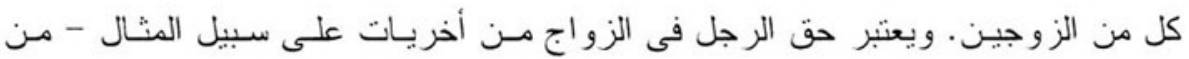

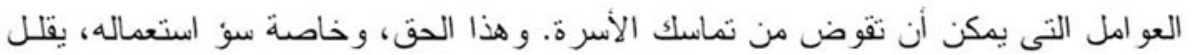

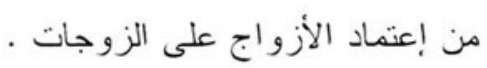

وقد لاحظت هو دفار (9/1 (191) مثلا أن كثير ا من الخدمات التى تقدمها المر أة تقليديا يمكن شر اؤها الأن من السوق (مثل الطعام، و الملبس، و غسبل الملابس وخدمـات

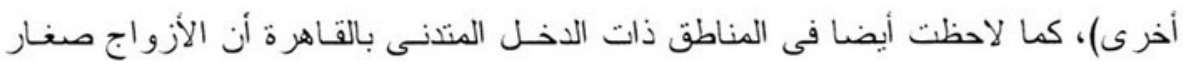
السن أقل إعثمادا على زوجاتهم لأنهم بقومون بشر اء هذه الخدمات الأن من السوق.

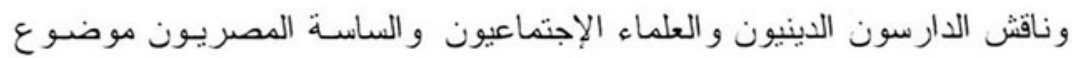

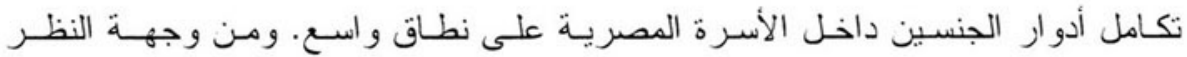
المصرية، فإن نكامل أدو ار الجنسـين لا يشـير إلى التقليل مـن قيمـة المـر أة أو انشطتها.

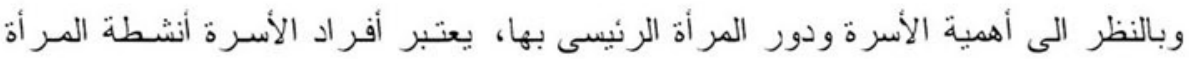

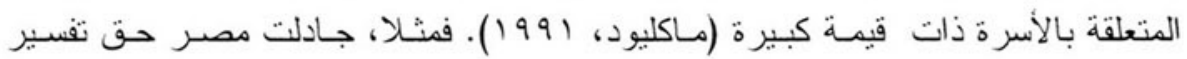
تحفظاتها تجاه المادة رقم 17 من الإتفاقية الدولية للقضاء على كافـة أشكال التمبيز ضـد

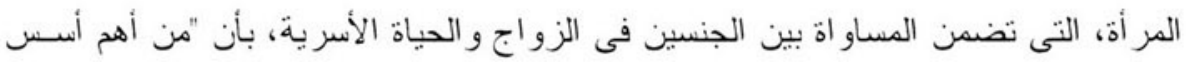


العلاقات (الزوجية) هو المساو اة فى الحقوق و الو اجبات التى تعزز هذه الصفة التكامليـة

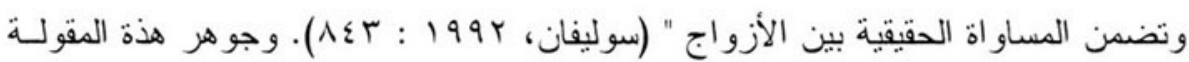

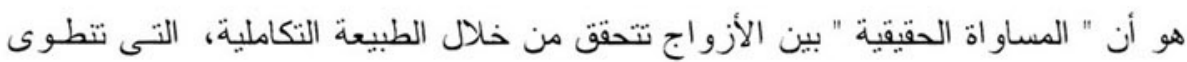

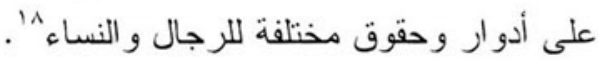

ويمنـح كل مـن القـانون المصـرى و الثـريعة الإسـلامية المستمد منهـا القـانون

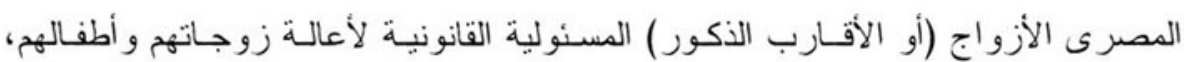

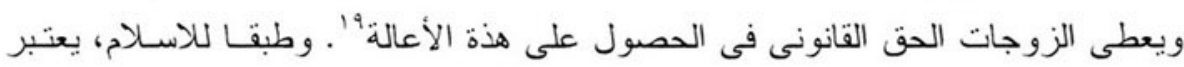

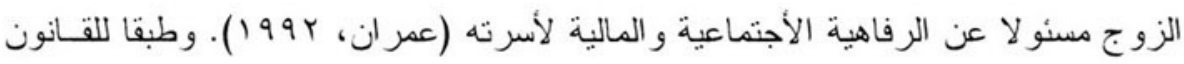

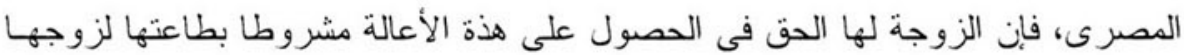

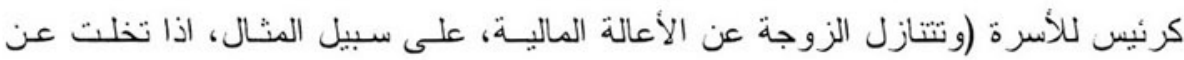

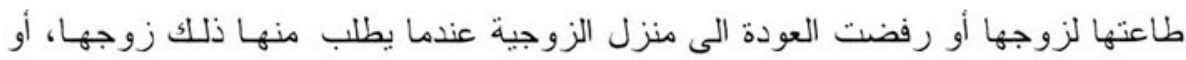

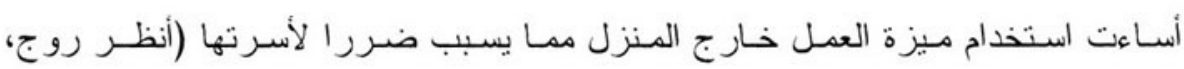

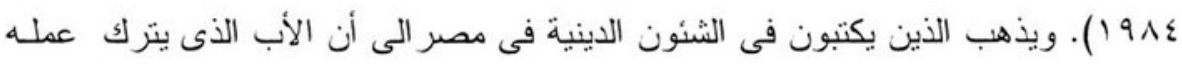

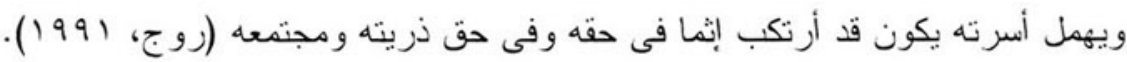
فالى أى مدى يكون الثقسيم التقليـدى للمسئولية الماليـة بيـن الرجلـ و المـر أة فـى

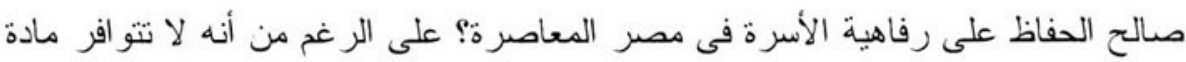

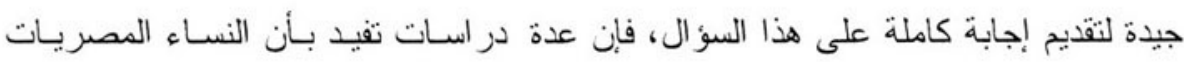

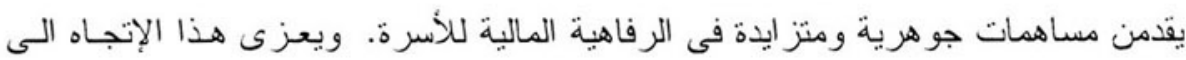

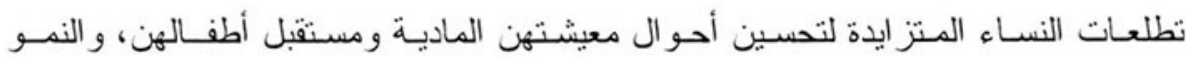

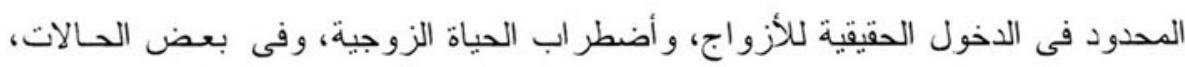

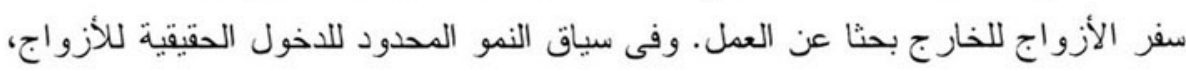

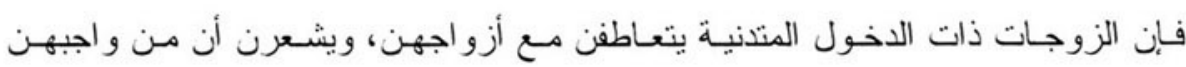

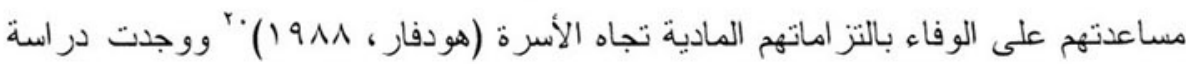

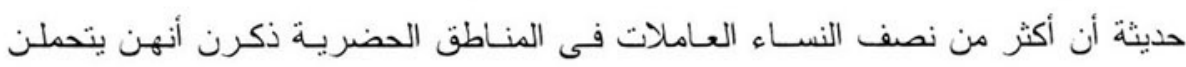

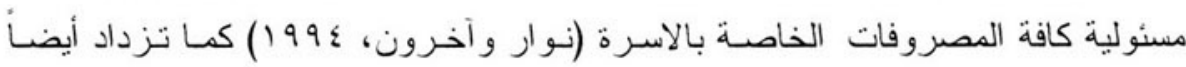

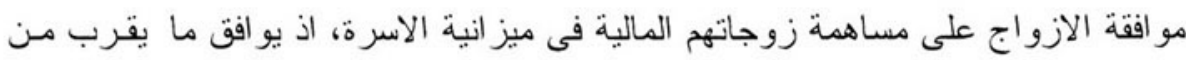

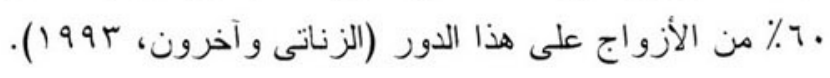




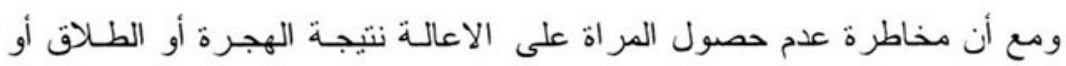

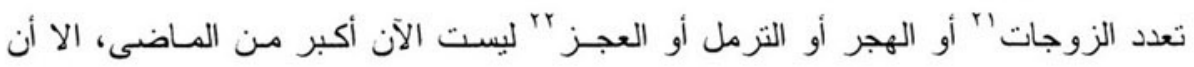

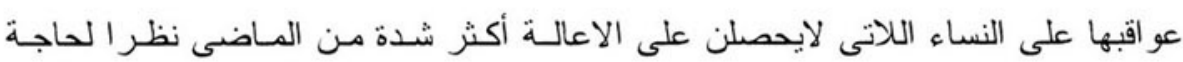

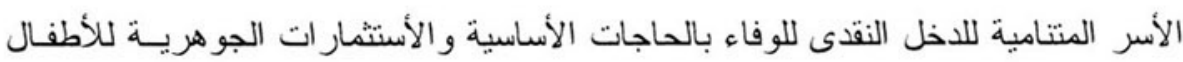
فى نطاق الأقتصاد الأخذ فى التحديث.

ومعظم الرجال الذين بعملون فى أعمال غير مهنية يتركون زوجاتهم فى مصر .

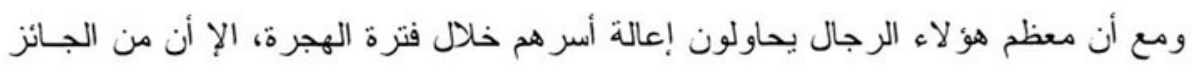

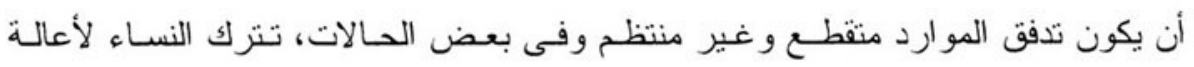

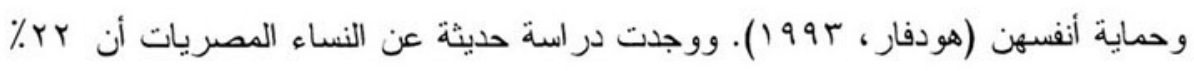

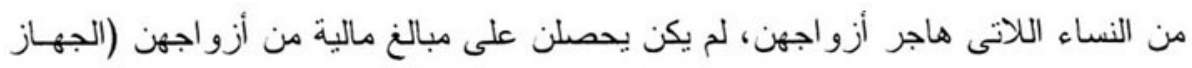

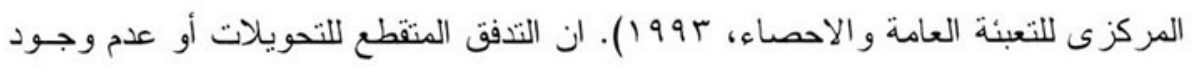

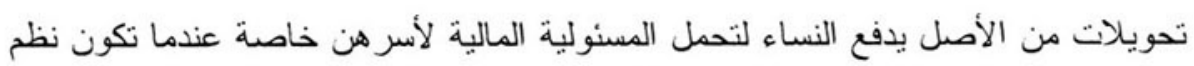

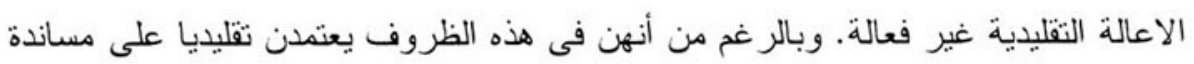

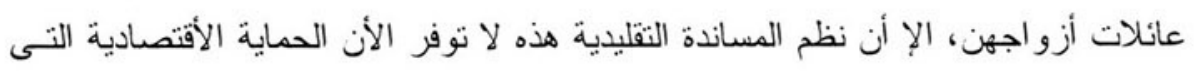

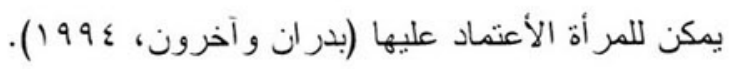

ولا يغير استعداد الزوجات لمسـاعدة أزو اجهن من أعتقـادهن بـأن الرجـال

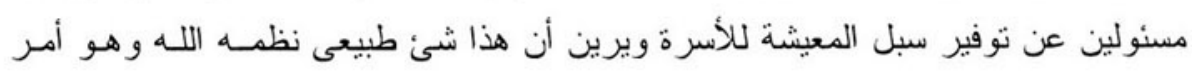

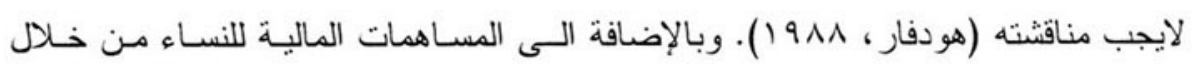

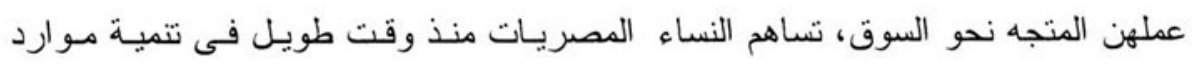

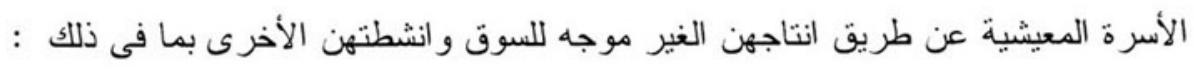

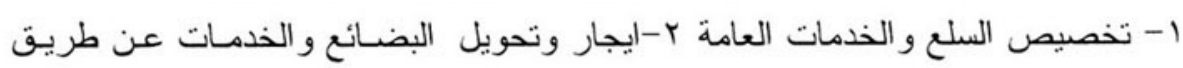

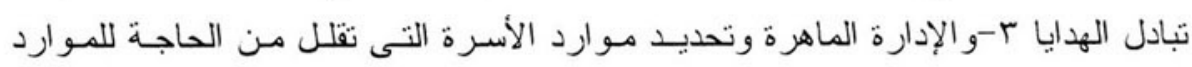

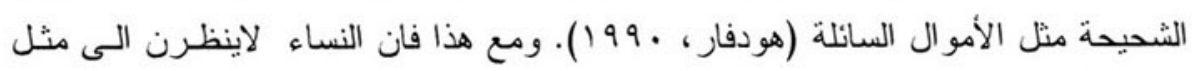
هذة الأنشطة باعتبار ها عملا (أنكر و انكر ، 9199 (199).

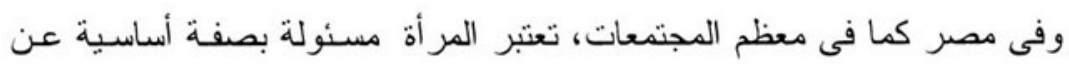

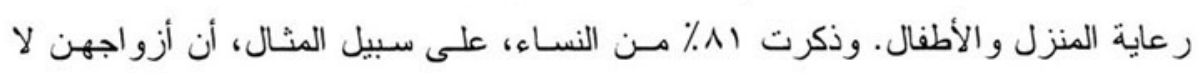


يقدمون لهن المساعدة فى الأعمال المنزلية (الجهاز المركـزى للتعبئة العامـة والاحصـاء،

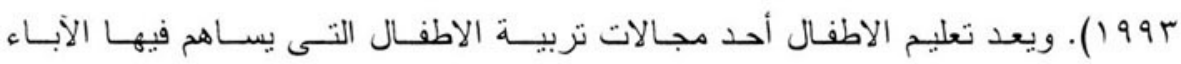

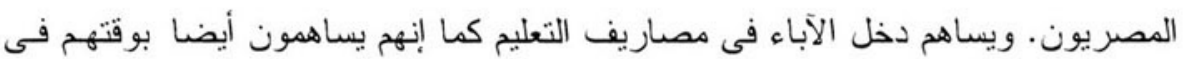
توصيل الأبناء الى المدارس ومساعدتهج فى أداء واجباتهج المدرسية.

ان كـلا مـن نز اجسع نوعيـة النظـام التعليمسى وازديـاد المنافسـة ز اد مـن أهميـة

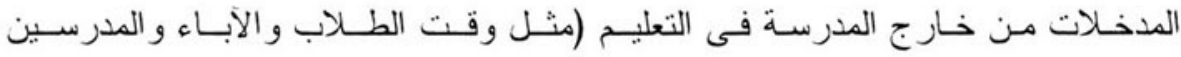
الخصوصيين)، ويتطلب ذلك أن يضحى الآباء بوقتهم و أمو الهم لضمان نجاح أبنـائهم فى ولى ولى

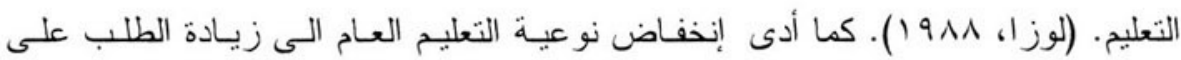

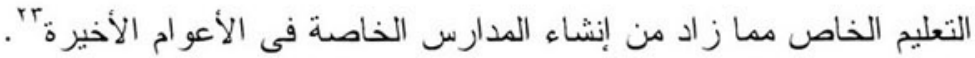

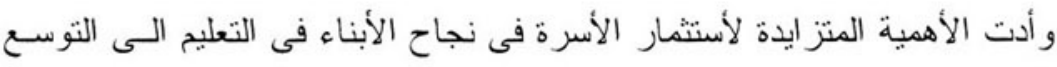

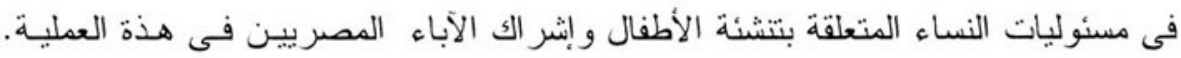
وذكرت بعض الأمهات المتعلمات أنهن يقضين عدة ساعات فى الإشـر اف على و اجبـات أطفالهن المدرسية ـ أما الأمهات غبر المتعلمات اللاتى يفتقدن المهارة لمسـاعدة أبنـائهن

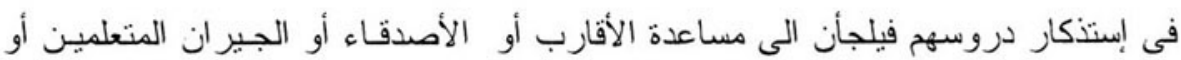

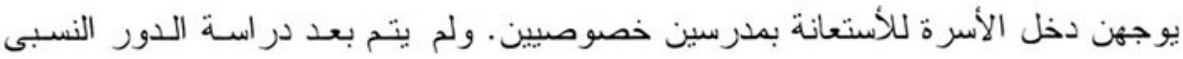

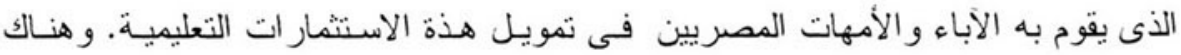

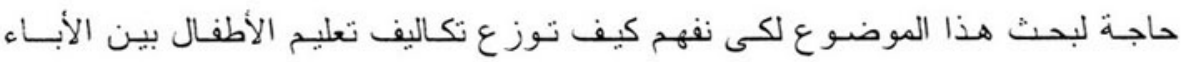

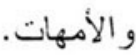

ويختلف تحكم النساء فى موارد الأسرة المعيشية بدرجة أكبر (هودفار ، 911 (1).

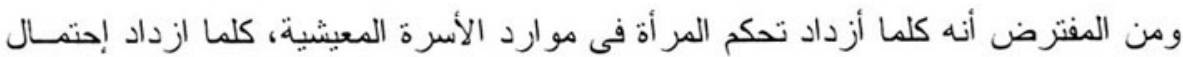

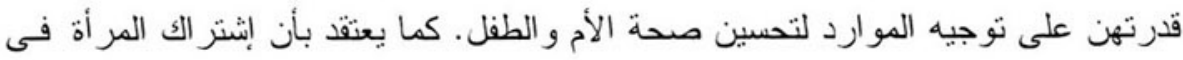
أنشطة الأنتاج المادى للأسرة المعيشية يعزز من هذا التحكم (شورنز و الطويلة، . ـ99 1).

ويتفاوت تأثبر عمل المر أة على التحكم فى موارد الأسرة المعيشية. فنتشير بعض

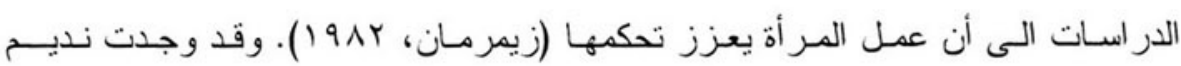

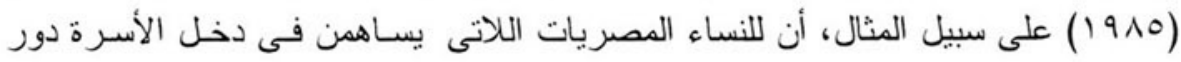

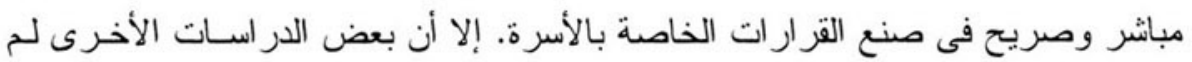


تجد تأثير ا يذكر لعمل المر أة على تحكمها فى موارد الاسرة (لينتش وفهمى، ع^9 1). وتتفق هذة النتائج المختلطة ور أى النساء حول ما اذا كان العمل يمنح المر أة سلطة أكبر الكرة بين أفر اد الأسرة. وقد كشفت دراسة حديثة أن حو الى نصف النف النسـاء المصريـات صرحن بأن للزوجة العاملة نفوذ فى إدارة المـنزل أكبر مـن نفوذ المـر أة التى لا تعمل (الجهـاز

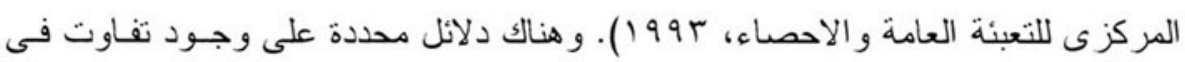

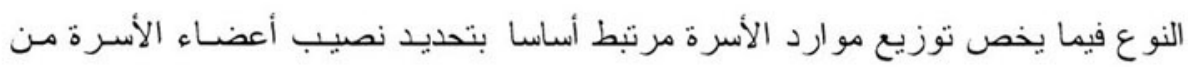

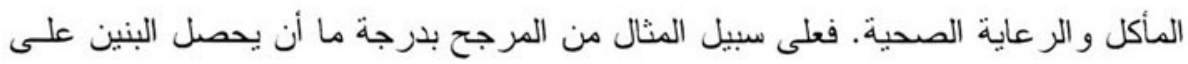

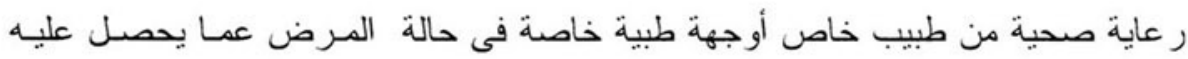

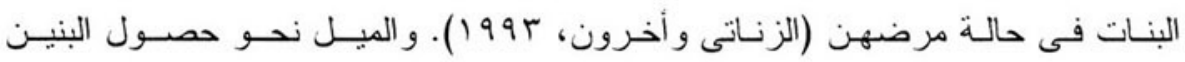

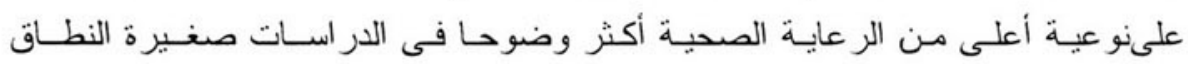

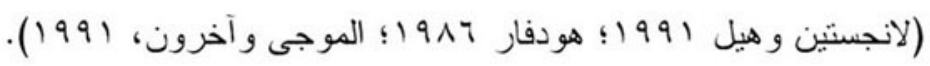

و لا تتساوى نسبة الدخل المنفق فى الريف المصـرى على الاحتياجـات الصحيـة

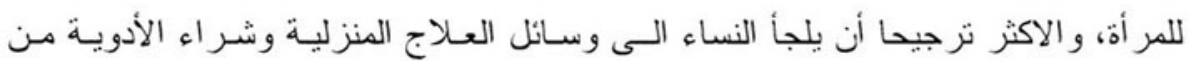

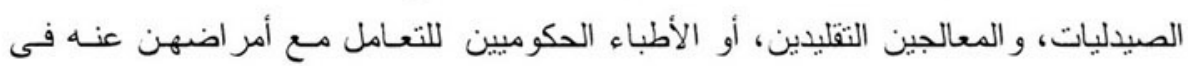

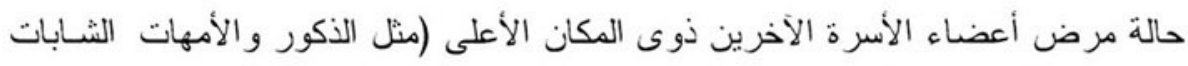

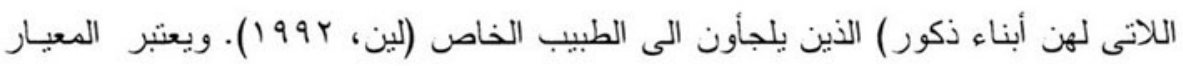

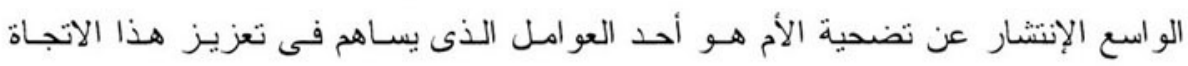

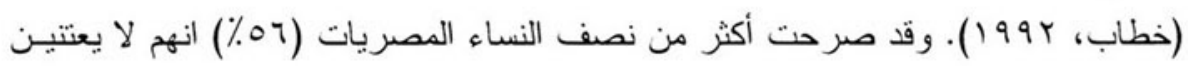

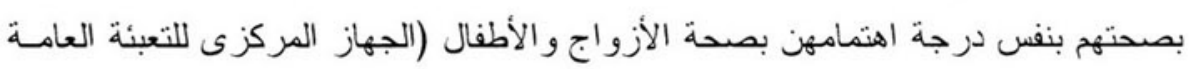

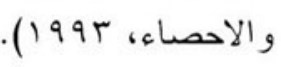

إستقلالية المر أة في العلاقات الحميمة وصنع القر ارات الجنسية والإنجابية

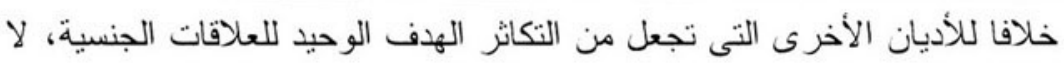

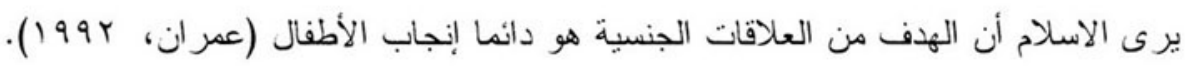

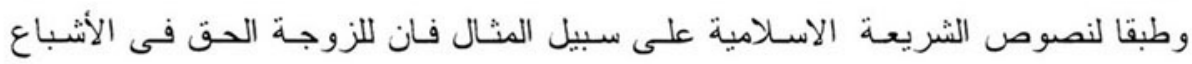

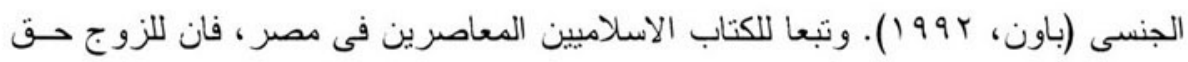

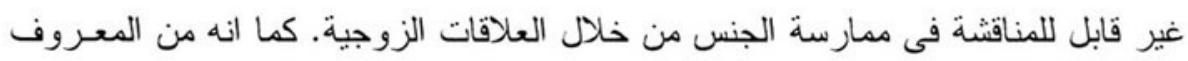

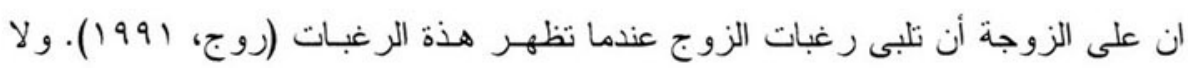


يعرف سوى القليل عن مدى مز اولة الإختيار ات الفردية من خلال العلاقات الزوجيـة بيـن

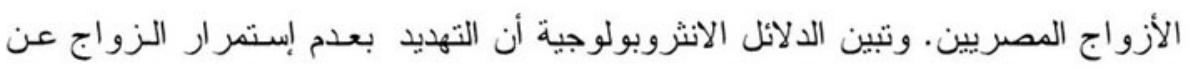

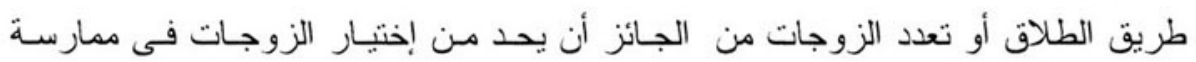

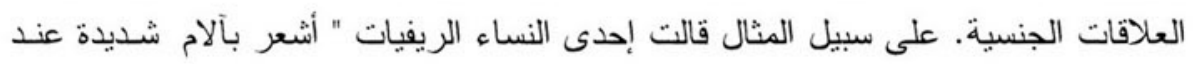

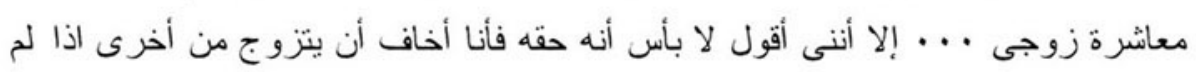

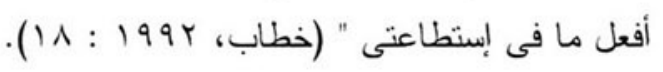

وتشير الدلائل الى ان الرجال و النسـاء المصرييـن ليـس لديهم دائهـا نفس التفضيلات أو النوجهات الخاصة بالخصوبة التى تتجه نحو تنظيم الأسرة. فعلى سبيل

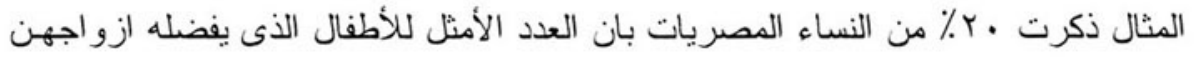

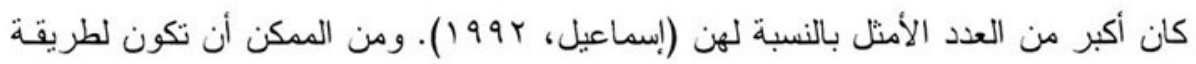

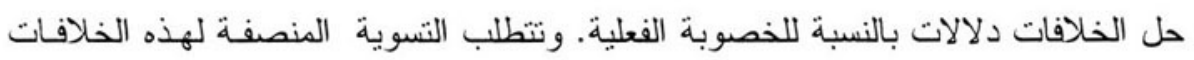
أن يقوم الأزواج بالمناقشة والمفاوضة حول رغباتهم الخاصة بالخصوبة و إستخدام وسـائل الفاتل

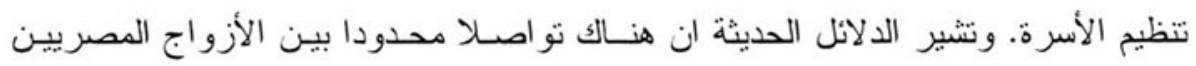

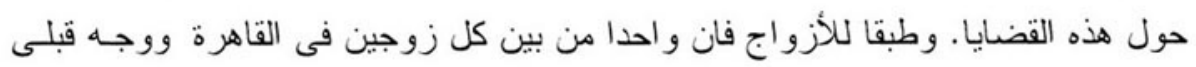

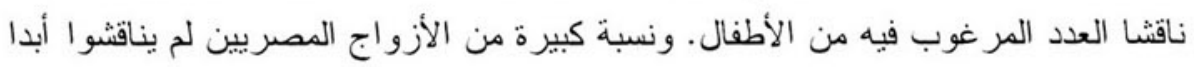

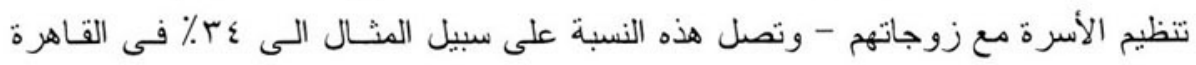

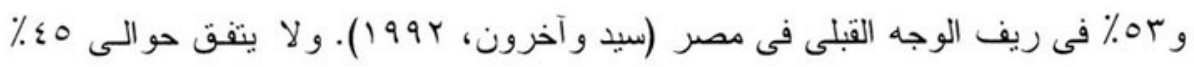

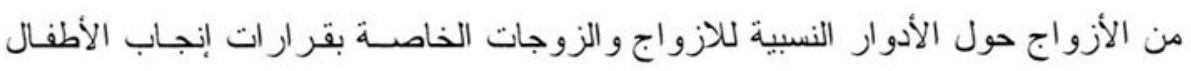

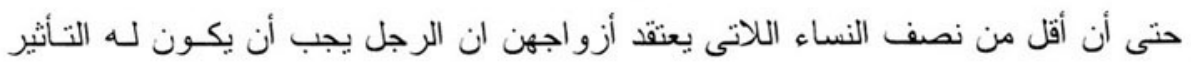

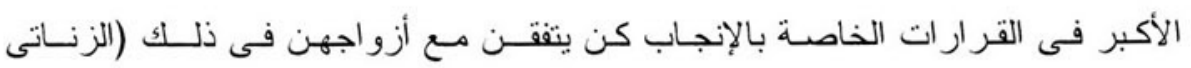

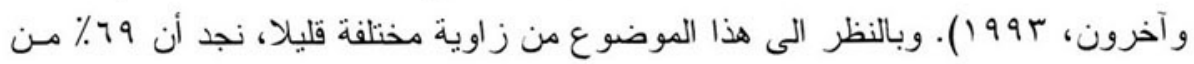

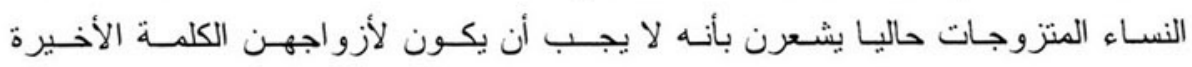

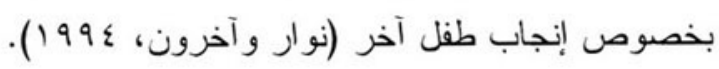

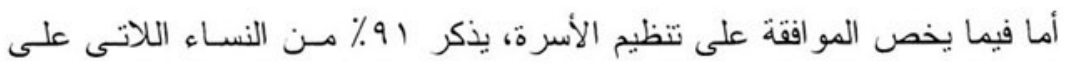

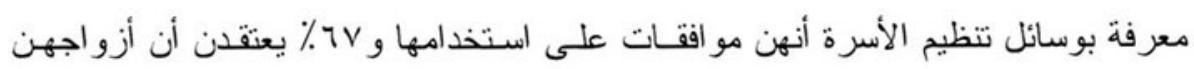

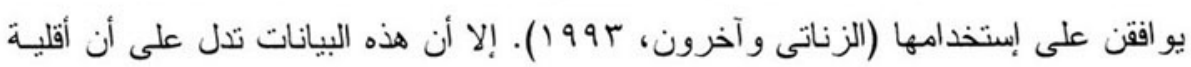

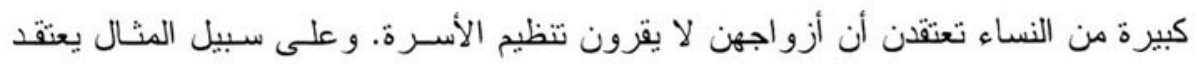


• ع ٪ من بين النساء اللاتى لا تستخدمن حاليا وسائل تنظيح الأسرة أن أزو اجهن لا يقرون

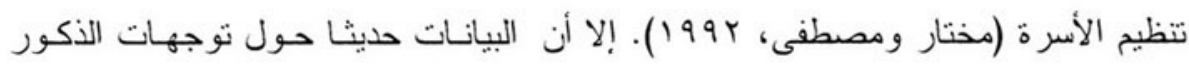

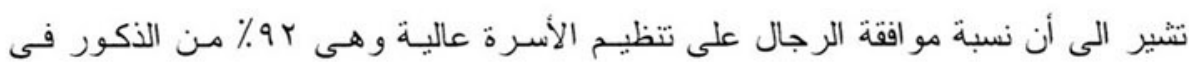

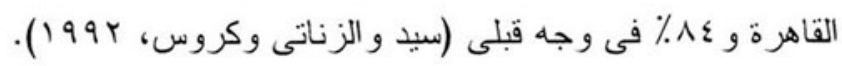

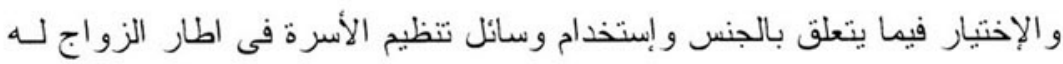

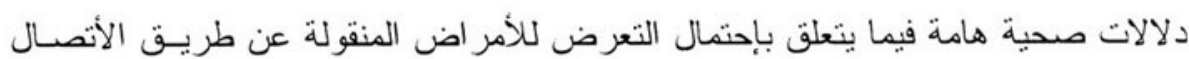

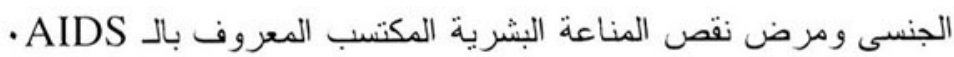

ولم ينشـر سـوى القليـل حـول إنتشـار الأمـر اض المنقولـة عن طريـق الأتصـال

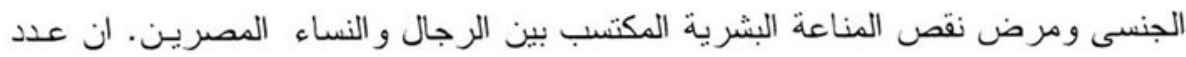

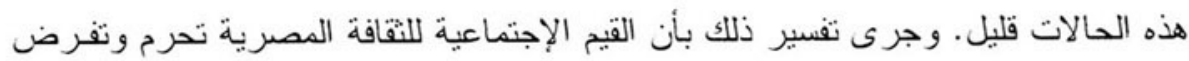

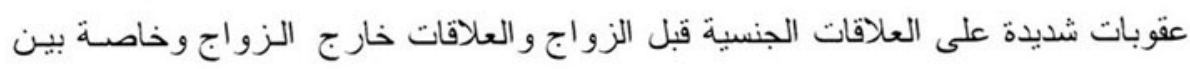

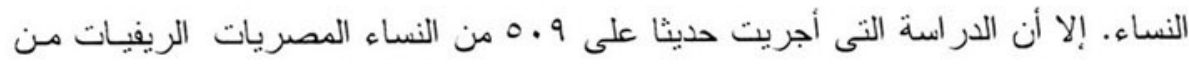

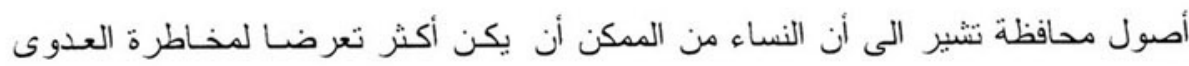

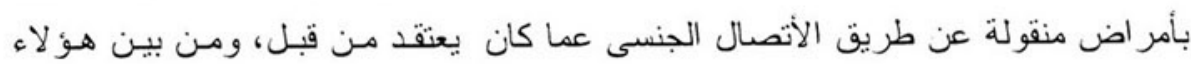

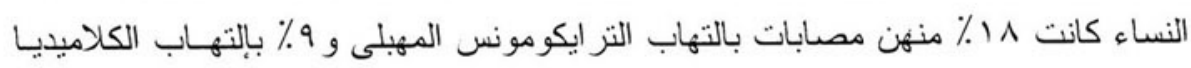

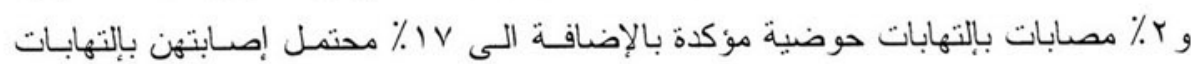
حوضية (يونس و آخرون، ب9911). و لأن إمكانية وصول بالإنافية الأزواج الى شريكات منعددات

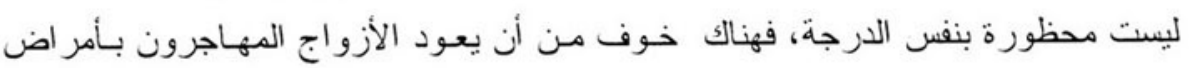
منقولة عن طريق الأتصال الجنسى وينقلون العدوى الى زوجاتهر.

وفى مصر ، شأنها فى ذلك شأن مجتمعات كثيرة أخرى، يعتبر العنف المـنزلى

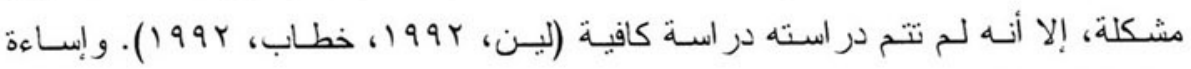

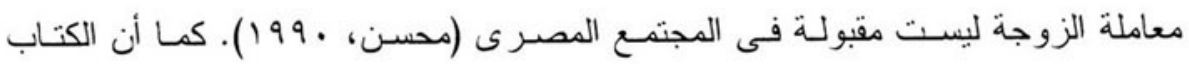

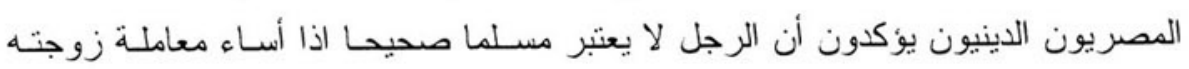

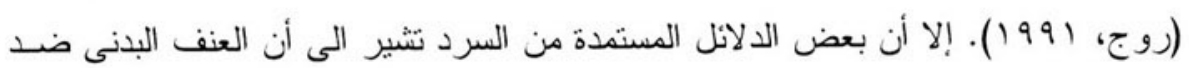

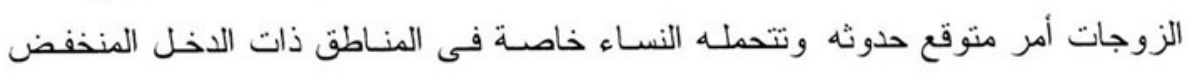

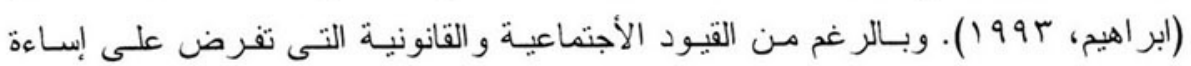


معاملة الزوجة، فان النساء اللاتى يفتقدن الى الحمابـة الأسـرية القويـة لديهن بدائل قليلـة

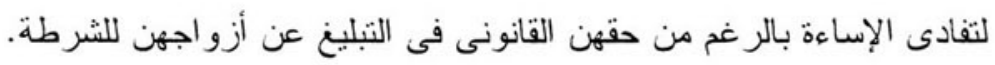

و الاغتصاب هو أحـد أكثر الجر ائم التى لا يتم التبلينغ عنها فى مصر وذلك

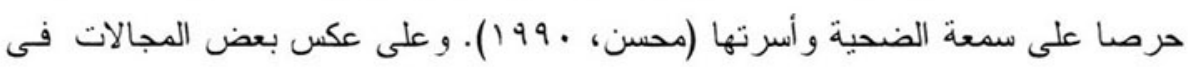

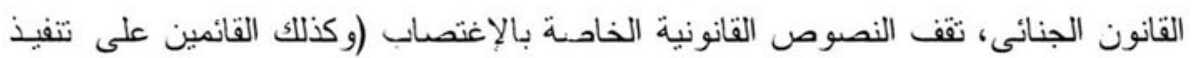

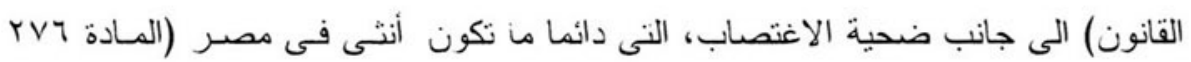

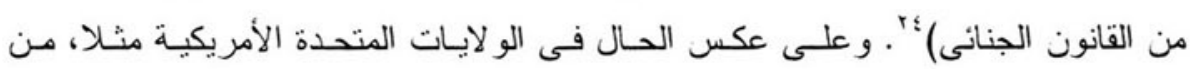

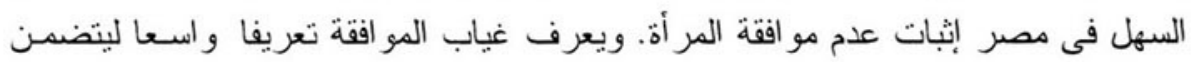

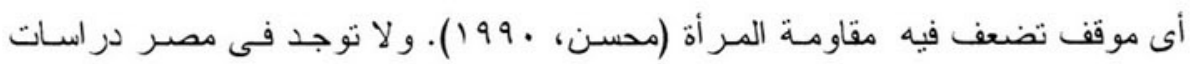

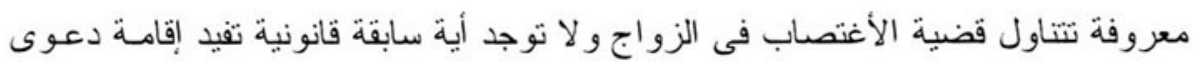
فى هذا المجال. دلالات عدم المساو اة فى النوع داخل المنزل على السلوك الديموجر افى

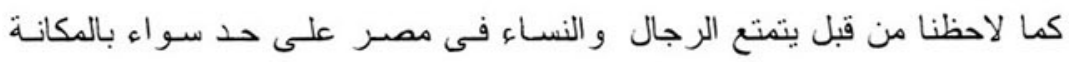

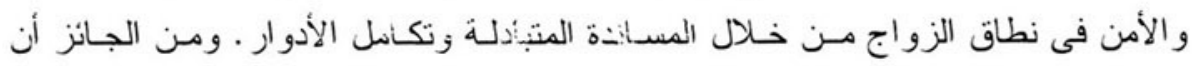
تتمتع الزوجات بنو ع من الإسنقلالية فى إدارة المنزل وحتى فى إدارة ممتلكاتهن الخاصة.

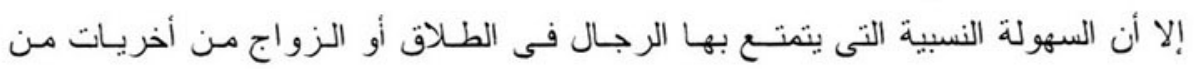

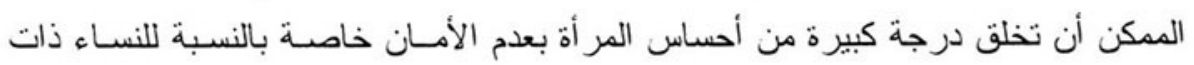

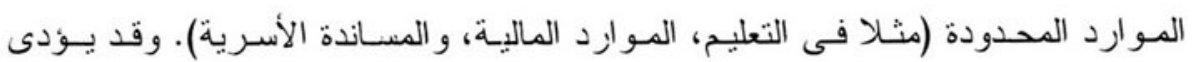

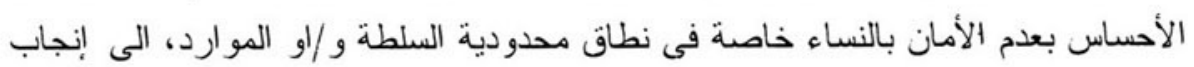

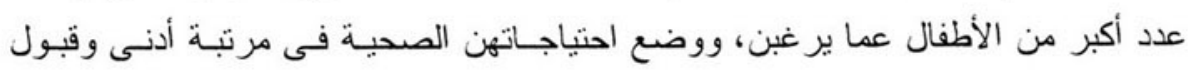
الهيمنة الجنسية. والاكثر ترجيحا أن نشعر النساء الاضعف بالآثار السـلبية لعدم المسـاواة

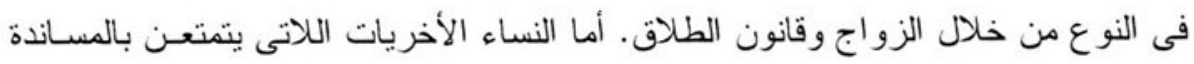

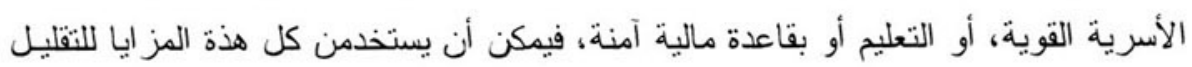

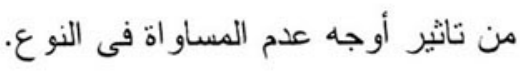

وتو اجه المر أة احتمال أكبر من الرجل فى ان تعيش وحدهـا كأرملـة على الأقل

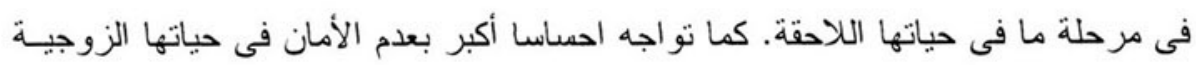

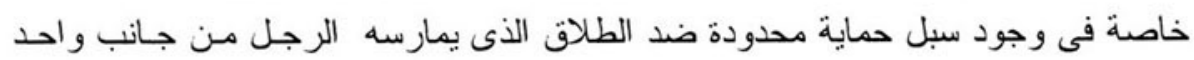




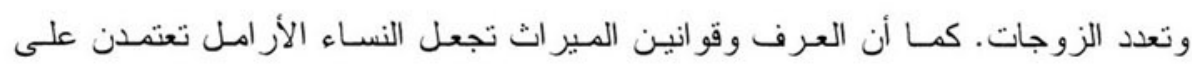

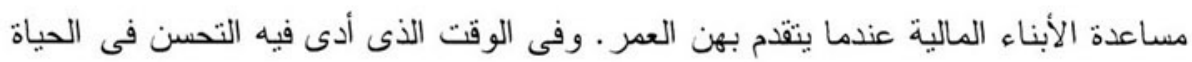

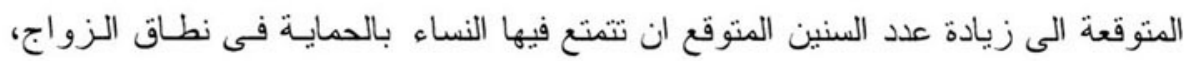

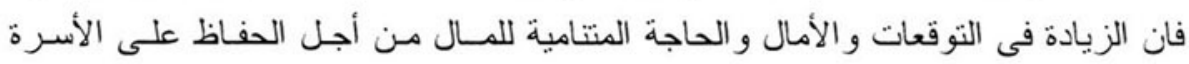
وذلك فى نطاق الأقتصاد الآخذ فى التحديث، أدت الى نتامى الآثار الأقتصاديـة السلبية

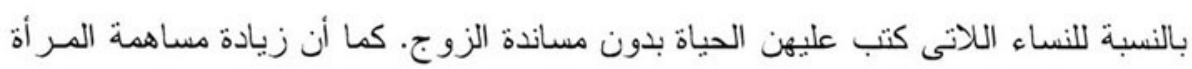

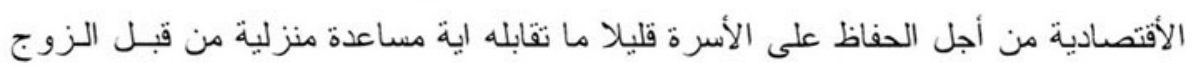

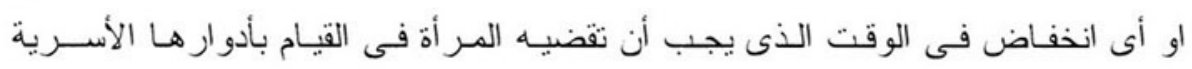

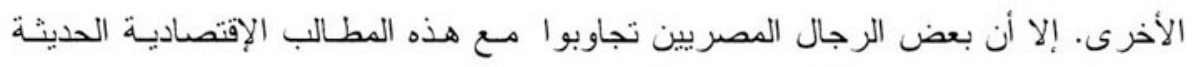

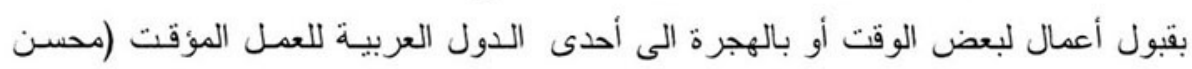

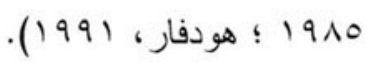

ومن الواضح أن كلا من الأم والأب يشعر ان بالزيادة فى تكاليف تتشئة الأطفال.

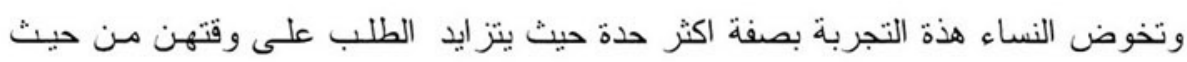

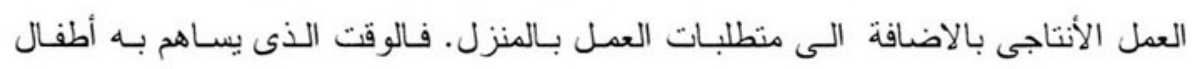

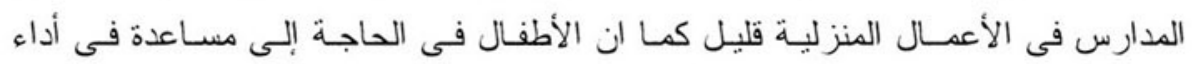

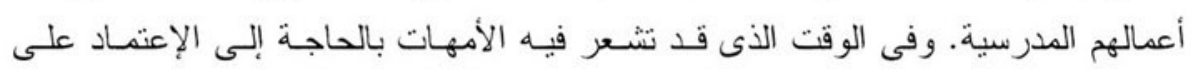

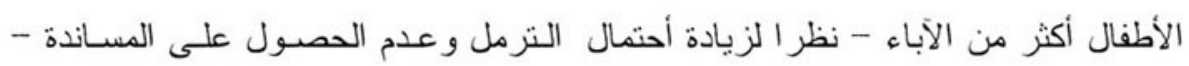

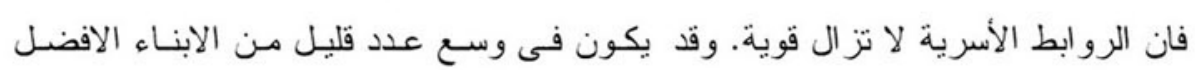

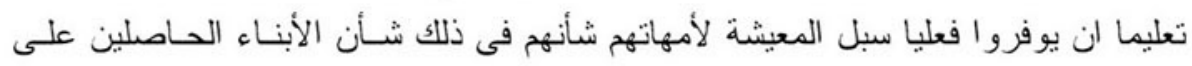

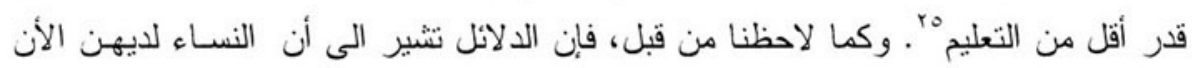
تفضيلات خاصة بالخصوبة أقل فى المتوسط من ازواجهن وربما كان ذلك نتيجة أن تكلفة

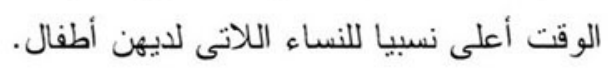

ومن المرجح بدرجة أكبر أن تكون للنسـاء اللاتى تثمتعن باستقلالية شـخصية

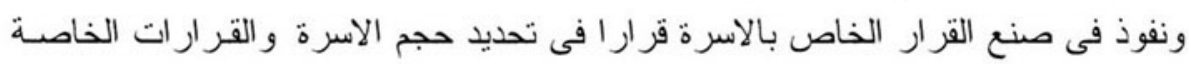

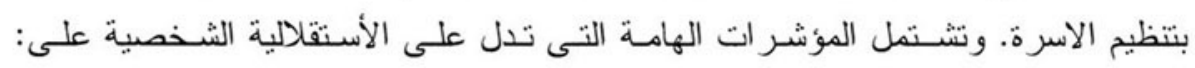

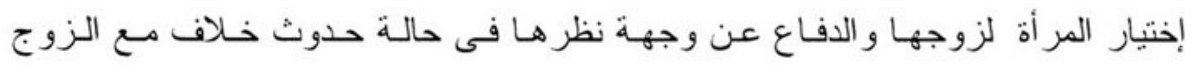

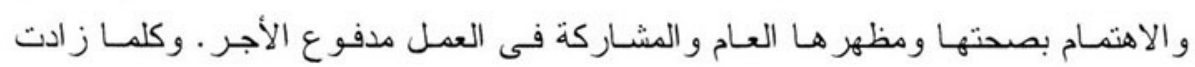




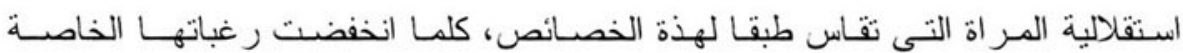
بالخصوبة وخصوبتها الفعلية · ولوحظت هذة العلاقة بصفة خاصة بين النساء صغيبرات

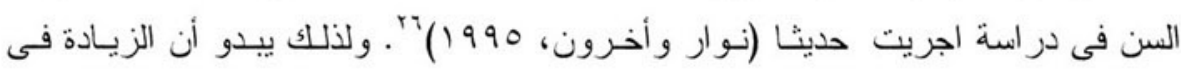
استقلالية النساء فى نطاق النظام الذى يسمح بالاستمر ار والتأكبد على عدم المساو اة فى النوع بالنسبة للأدوار و المسئوليات المنزلية، قد تؤدى الى انخفـاض أكثر فى الخصوبـة. وتحدث هذة النقلات عندما نمر النساء بتجربة زيادة نصييهن مـن نكاليف تتشـئة الأطفـال وزيادة القر ار فيما بخص بقرار ات الخصوبة ونتظيـم الأسـرة فى الوقت نفسـهـ. و السؤال الأن هو اذا كان من الممكن أن يحدث هذا التقدم فى استقلالية المر أة فى المنـاطق الريفيـة خاصة فى الوجة القبلى وكيف سيحدث ذلك .

\section{عدم المساواة فى النوع فى الحياة العامة}

طبقا للقانون المصرى و الشريعة الإسلامية ، فى معظم الحسالات، فـان النسـاء يتمتعن بالمساو اة مع الرجال في معظم أوجـه الحبـاة العامـة وبصفـة خاصـة فيى التعليـم، و التجارة و العمالة، و التملك. و التعليم حق للجميع طبقا للدستور المصرى وقد عـزز النص على " مجانية التعليم " من المرحلة الأبتدائية وحتى مرحلة التعليم الجامعى وقو انين التعليم

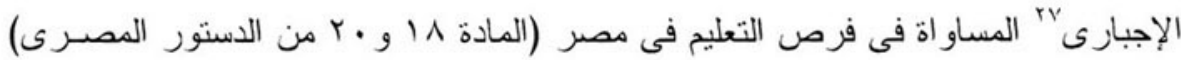
(ذو الفقار ، ب99 1 ج). ويأتى التأكيد الإضافى على مبدأ المساو اة فى فرص التعليم مـن الأسلام نفسه. ويشير القر آن و الحديـث الى أن التعليـم و الثقافـة أساسيين بالنسـبة للعقيدة و التقافة الأسلامية وأن النساء مطالبـات بـالتعليم شـأنهن فى ذلك شـأن الرجـال (عمر ان. ץ99 ( ). كما أن للنساء الحق فى المسـاو اة فى فرص العملى، و الأجـر المتسـاوى للعمل المتساوى ^^ و المر اعاة الخاصة لمسئولياتهن الأسرية. و نمنح الثريعة الإسلامية و القانون المصرى النســاء الحتق فى التملك المسـتقل والحـق المطلـق فى التصـرف فى أملاكهن

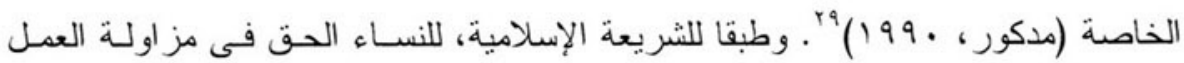
بالتجارة كما أن لهن صفة قانونية مساوية للرجال ومعنى ذلك أنهن يستطعن القيام بتدابـير تعاقدية وتنفيذ الأعمال بدون الحاجة لمو افقة الأزواج أو الأباء (عمران، ب99 ا ). وبالر غم من الحقوف المشتركة بين الرجال و النساء، فهم بشتركون بدرجة متفاوته فى الحياة العامة. وتعد الأنماط الثاريخية والأختلافات فى الحقوق و الأدوار داخل الأسرة عو امل أساسية فى شر ح هذه الأختلافات. وفى مجال العمل، كان بحد التضارب القانونى المتأصل بين فوانين 
الفرص المتساوية وتشريعات العمل الواقية، من فرص النساء فى العمل. وقد صدر عدد

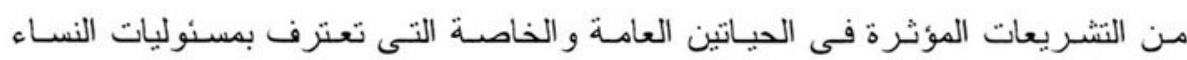

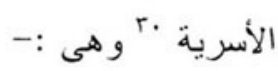

(1) الحق فى أجازة أمومة مدفو عة الأجر لمدة ثلاث أشهر بحد أقصىى ثلاثنة أطفال فى

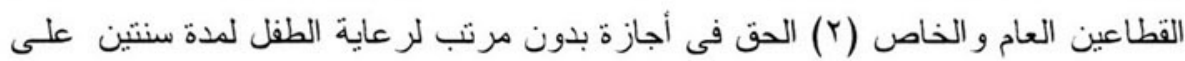

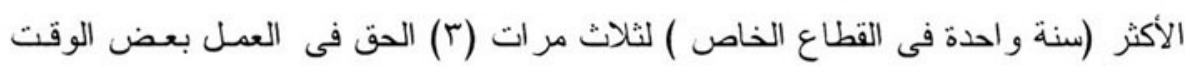

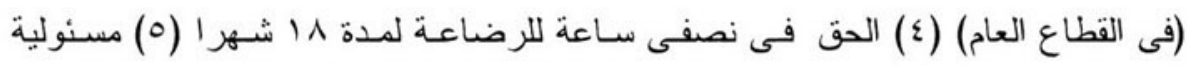

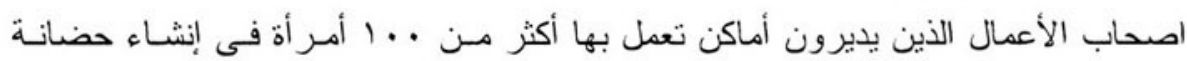

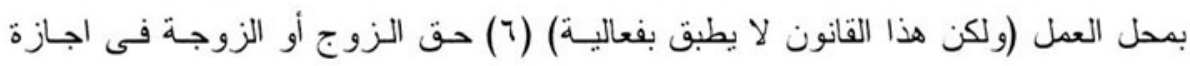

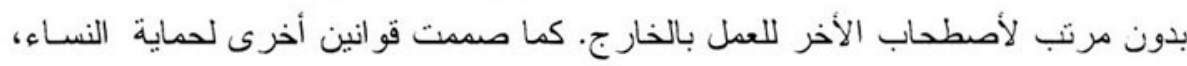

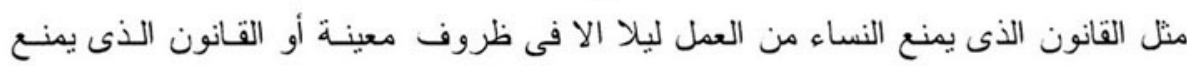

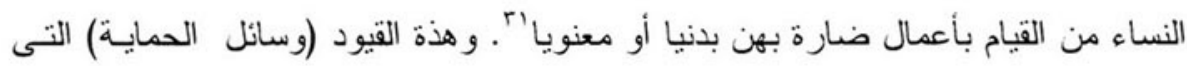

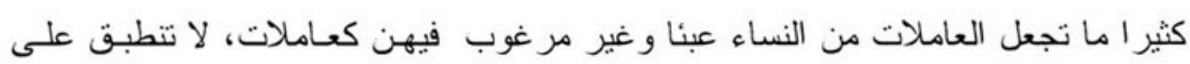

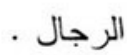

ويعد موضو ع ملاعمة عمل النساء محل مناقثات علنية نشطة بين القادة الدينيين

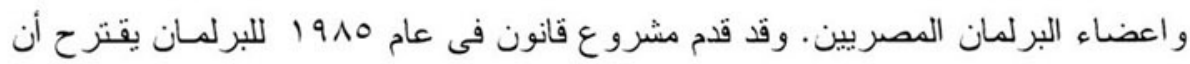

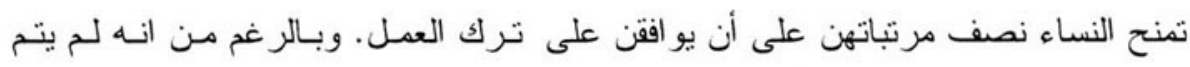

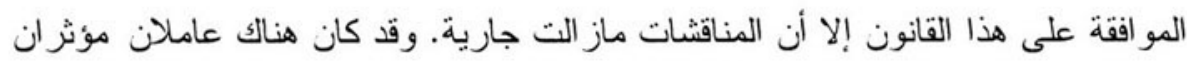

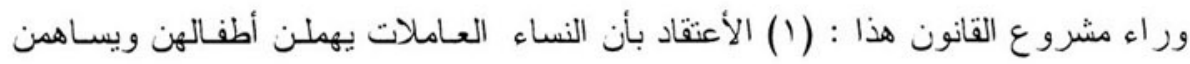

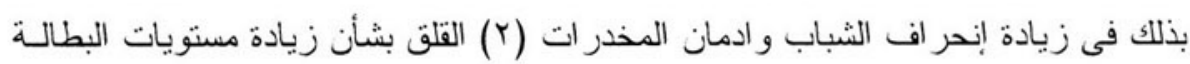

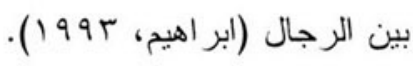

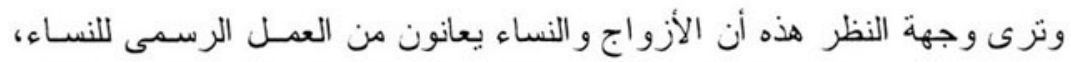

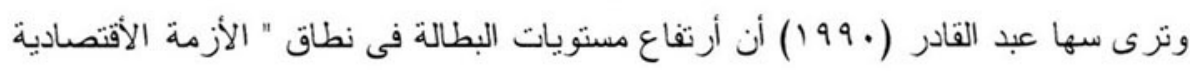

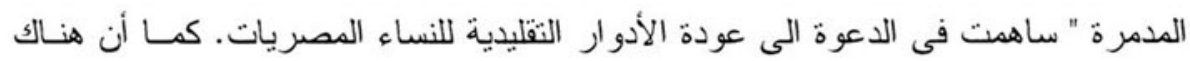

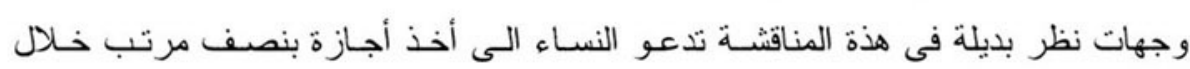

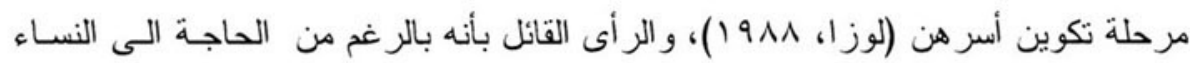


فى عملية التتمية، إلا انه يجب مساندة النساء العاملات بتقديم خدمات أفضل لهن (بما فى

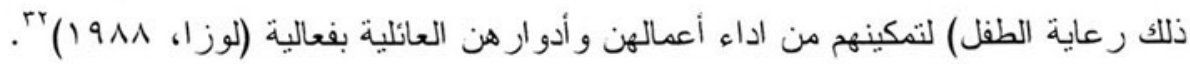
وتعكس هذة الآر اء إهتماما بالغا بحماية ادوار النساء التقليدية. وقد غابت بوضوح من هذا

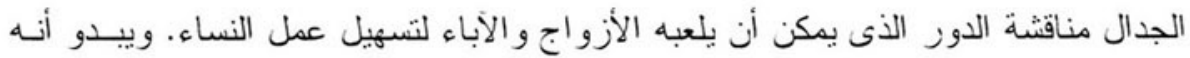

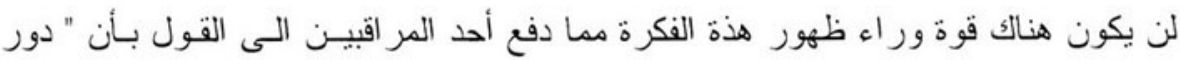

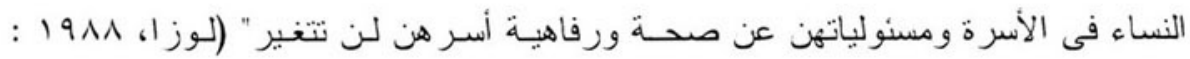

وتأخذ المناقشة أبعادأ إضافية على أساس الادعاء بأن المر أة ممنو عة من العمل

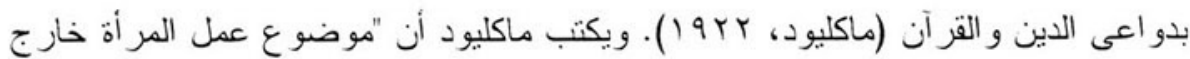

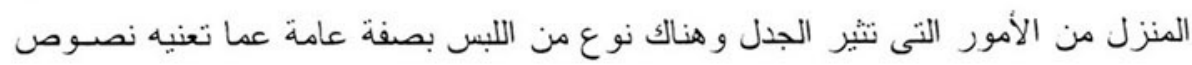

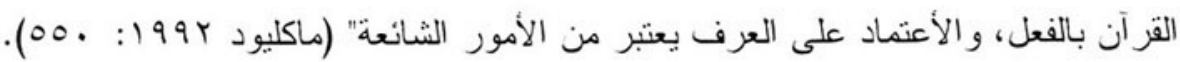

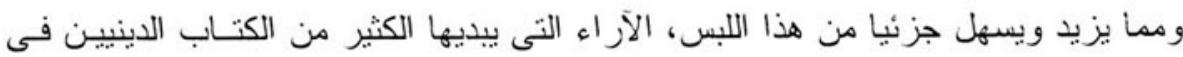

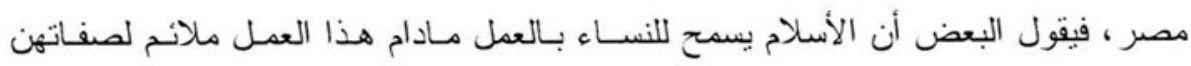

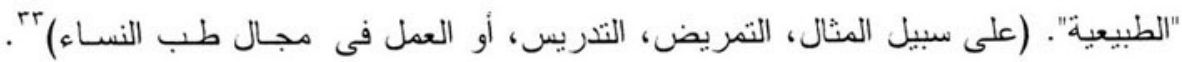

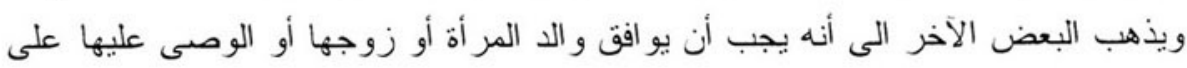
عملها خاصة اذا كان يحصل على دخل كاف لأعالتها في حالـة غبـاب مسـاهمتها الماليـة

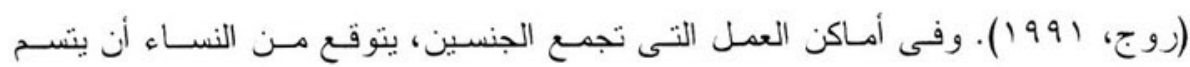

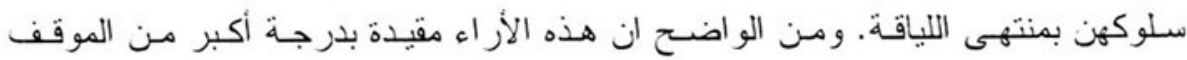

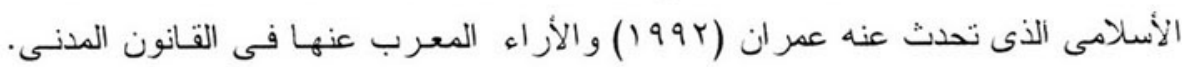

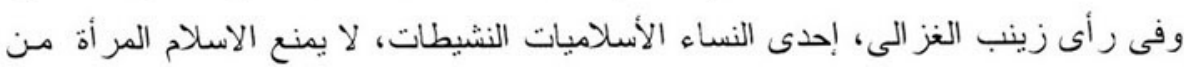

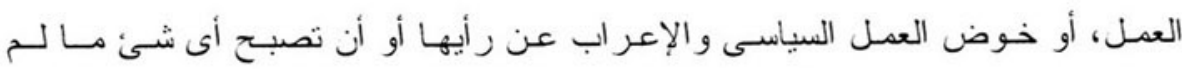

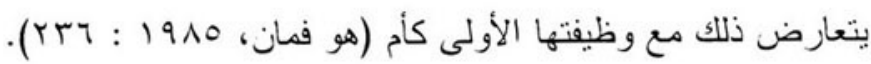

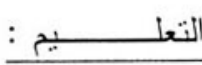

بالر غم من إنخفاض نسبة السكان الأمييـن على مدى الخمسـة و العشرون عامـا الماضية، من • V الى •ه ٪ من سكان مصر (أنظر الجـدول ع)، إلا أن الفجوة الخاصـة

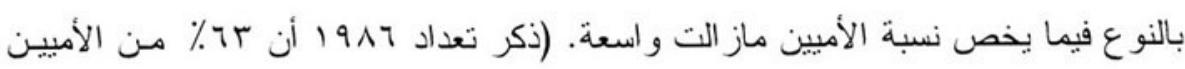

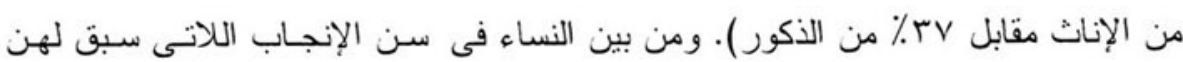


الزواج، إنخفضت نسبة من لم يحصلن على تعليم من ـ ٪ بين النساء فـى الفئة العمريـة

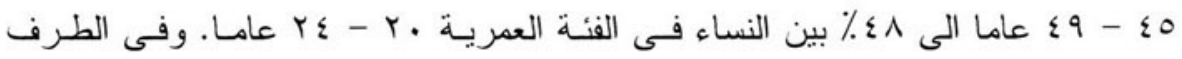
الآخر من درجات التعليم، إرتفعت نسبة النساء اللاتىى أتممن تعليمهن الثانوى أو التعليم

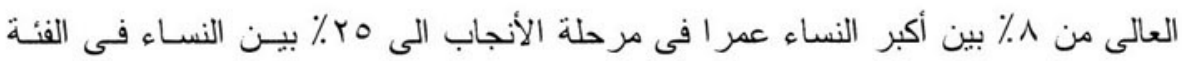

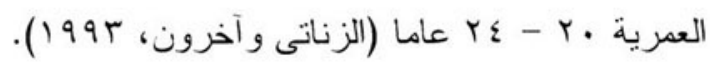

$$
\begin{aligned}
& \text { الجدول رقم ع } \\
& \text { تطور الأمية حسب النوع · } 1 \text { سنوات فأكثر } \\
& \text { سنو ات مختارة } \\
& 1917 \text { - } 197 .
\end{aligned}
$$

\begin{tabular}{|c|c|c|c|c|}
\hline \multirow{2}{*}{ معدل أمية الإحاث } & \multicolumn{3}{|c|}{ النسبة المئوية } & \multirow[t]{2}{*}{ سنة التعداد } \\
\hline & الإناث & الذكور & الاجمالى & \\
\hline $1, \varepsilon$ & $\Lambda \varepsilon$ & 09 & v. & 197. \\
\hline $1, v$ & vr & $\varepsilon r$ & or & 1987 \\
\hline $1, v$ & ir & rv & 0 . & 1917 \\
\hline
\end{tabular}

المصدر : الجهاز المركزى للتعبئة العامة والإحصاء ـ التعداد المصرى للأعواج .9719 1977 ، 1919 ـ.

وارتفعت نسبة القيد الكلية فى مرحلة التعليم الإبتدائى بصفة مثبرة حتى وصلت الى درجة تقترب من التسجيل الكامل، وتصل نسبة المقيدين فى مرحلة التعليم الثانوى من من ولئي

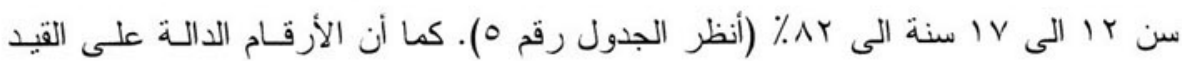

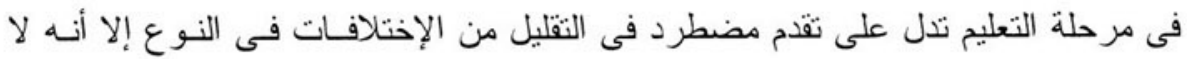

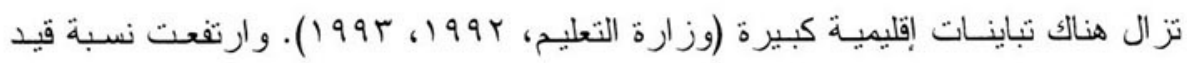

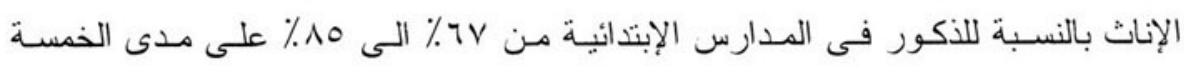

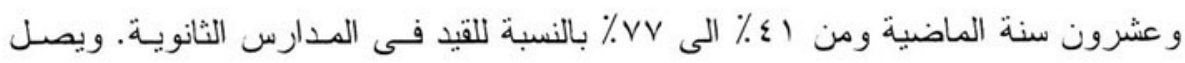

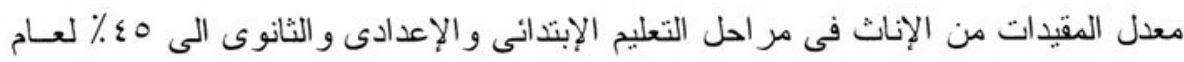

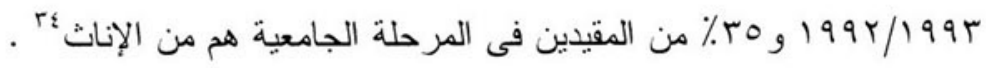

وللنساء المصريات تطلعات تعليمية عاليـة بالنسبة لأطفـالهن خاصـة فى علاقـة

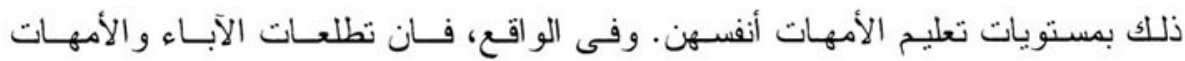

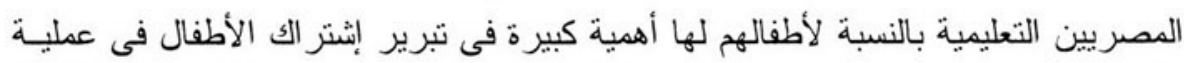




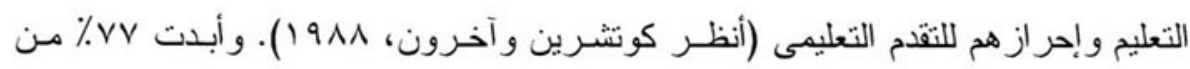

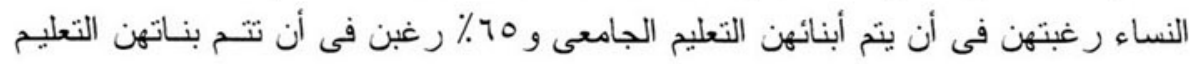

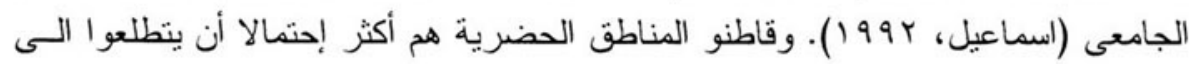

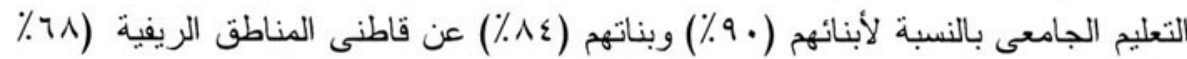

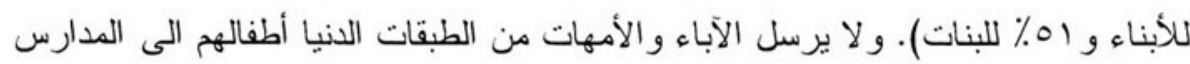

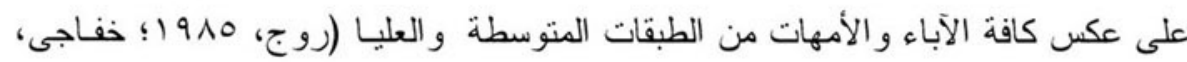

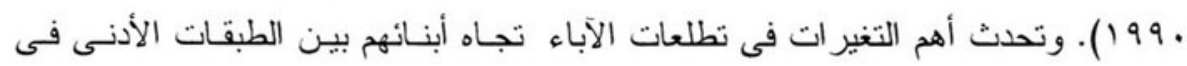

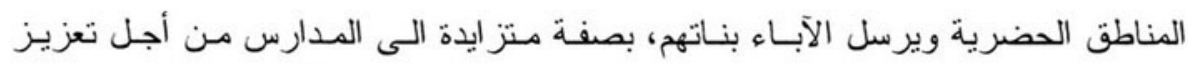

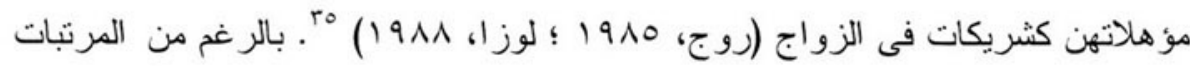

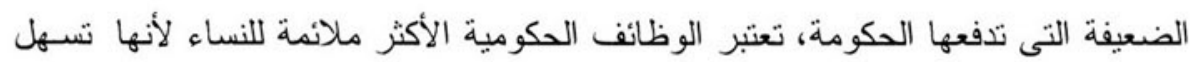

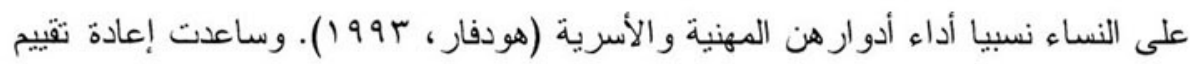

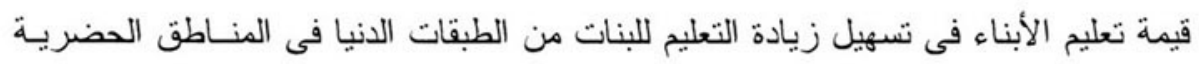

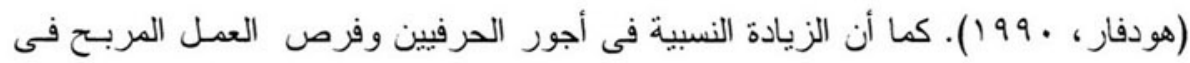

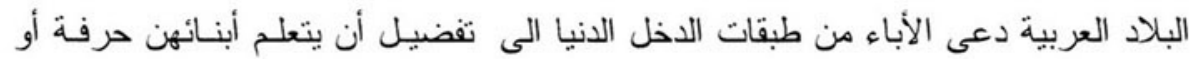

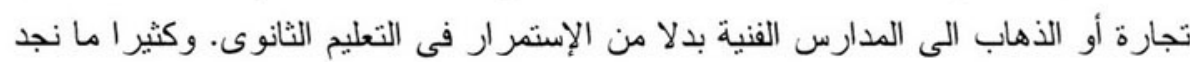

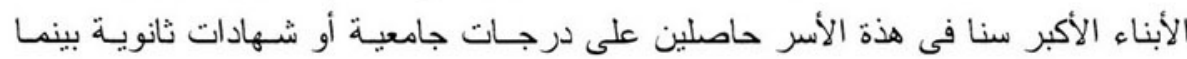

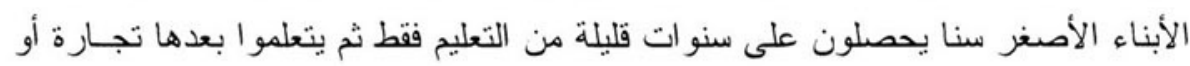

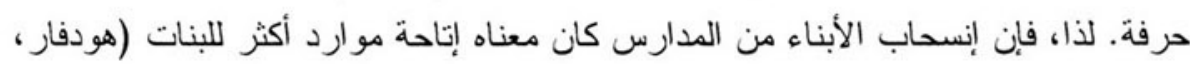

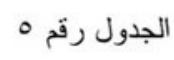

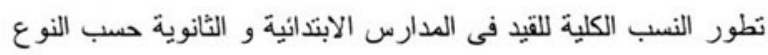

$199 .-1970$

\begin{tabular}{|c|c|c|c|c|c|c|c|c|}
\hline \multicolumn{4}{|c|}{ الثانوى ( } & \multicolumn{5}{|c|}{ الابتدائى ( 11 - 11 ) } \\
\hline للاكور & الإخاث & ال الذكور & ال الإجمالى & للإلإناث & الإحاث & الأكور & 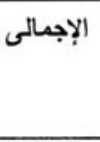 & السنة \\
\hline$\cdot, \varepsilon)$ & 10 & rv & $r 7$ & $\cdot, \mathrm{TV}$ & 7. & 9. & $v$. & 1970 \\
\hline., 0 . & $r r$ & $\varepsilon 7$ & ro & $\cdot, 77$ & ov & ᄉ V & VY & $19 v$. \\
\hline., 07 & $r 1$ & 00 & $\varepsilon r$ & $\cdot, \mathrm{TV}$ & 7. & 19 & vo & 1980 \\
\hline . & \&1 & 77 & $0 \varepsilon$ & $\cdot, V Y$ & 70 & 9. & $\mathrm{v}$. & 191. \\
\hline$\cdot, \vee$. & $0 \leqslant$ & VV & 77 & $\cdot, \wedge 1$ & $\Lambda r$ & 1.1 & 91 & 1910 \\
\hline$\cdot, \mathrm{VV}$ & vi & $9 Y$ & Nr & $\cdot, \wedge \top$ & 9. & 1.0 & 91 & 199. \\
\hline
\end{tabular}

المصدر : هيئة اليونسكو ، كتاب الإحصاء السنوى ( سنوات عدة حتى بو 199 ) . 
و الحافز الآخر للزيادة فى تعليم البنات هو رغبة الآباء من طبقات الدخـل الدنيـا،

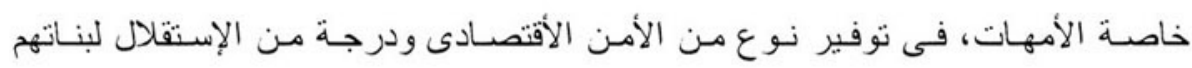

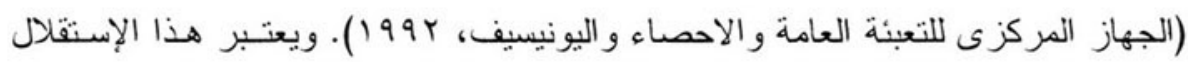

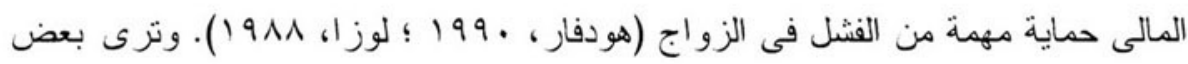

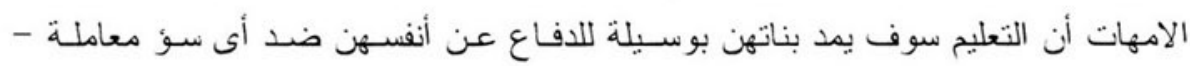

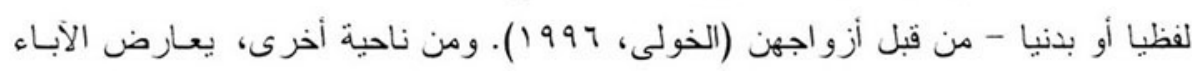

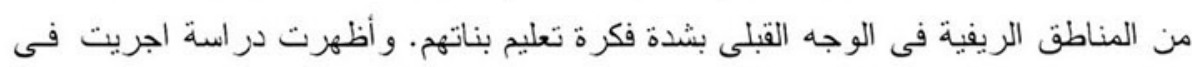

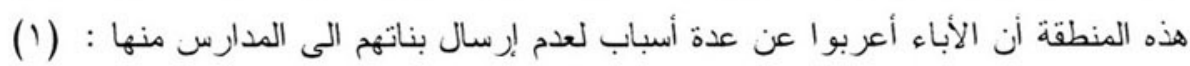

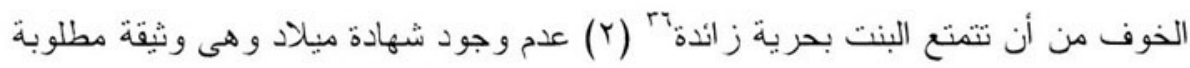

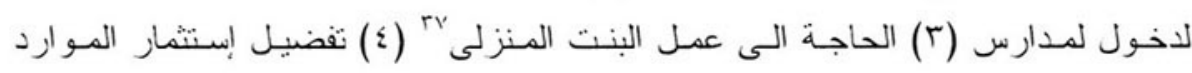

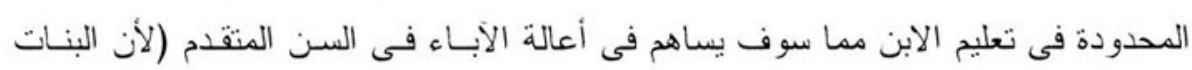

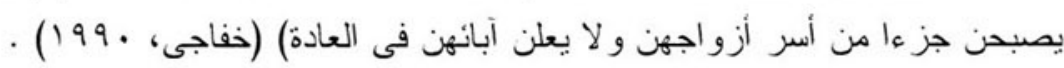

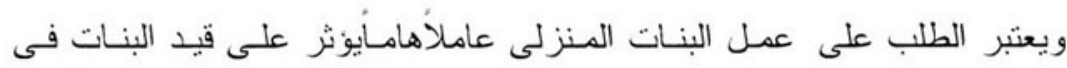

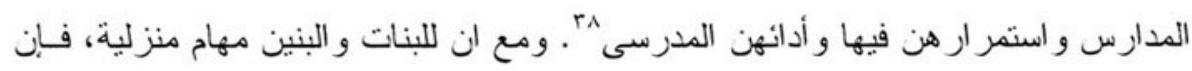

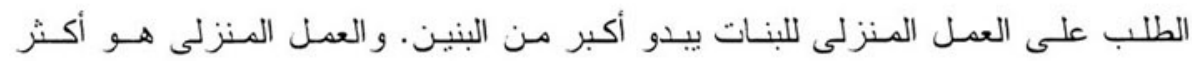

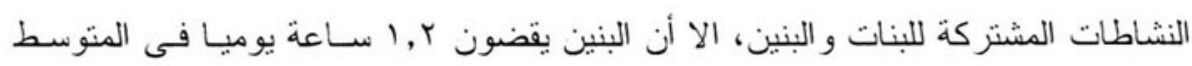

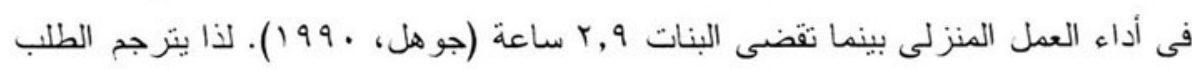

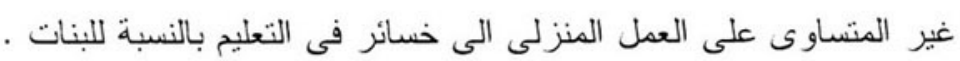

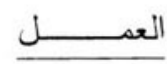

هناك مبدأن همـا أسـاس الحقوق الممنوحـة للنسـاء في قـانون العمل المصـرى

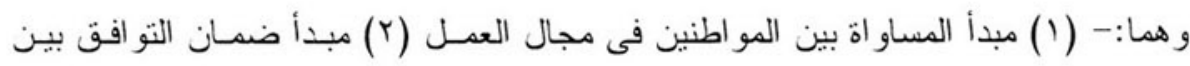

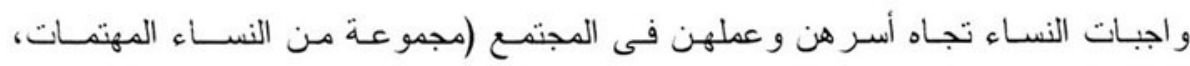

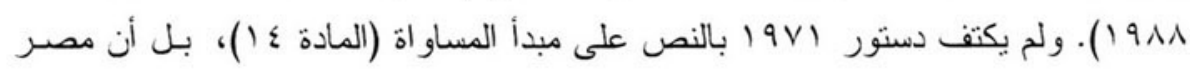

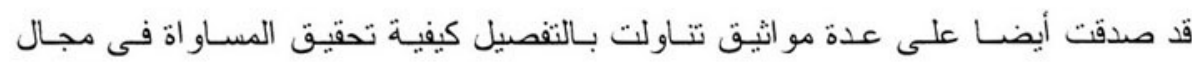

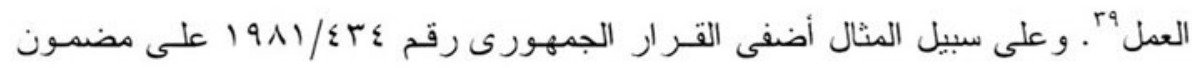

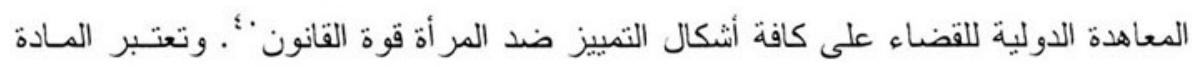

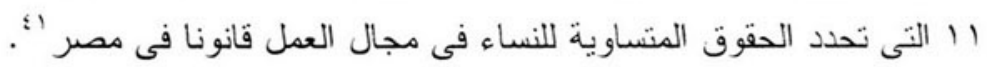


وبالر غم من المساو اة ( الفعلية ) في مجال حقوق العهـل التى تثتـع بهـا النسـاء

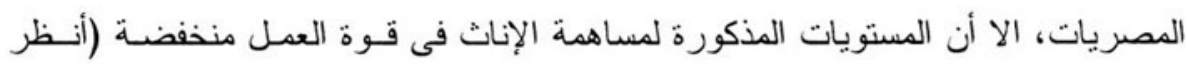

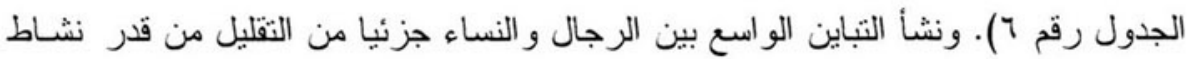

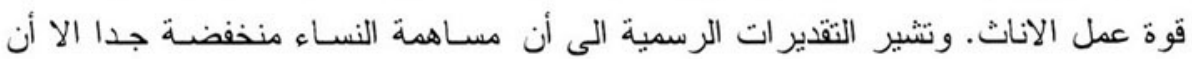

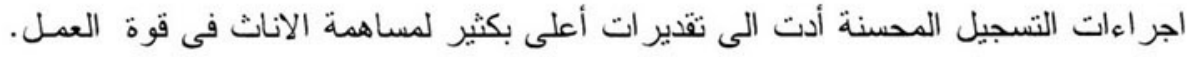

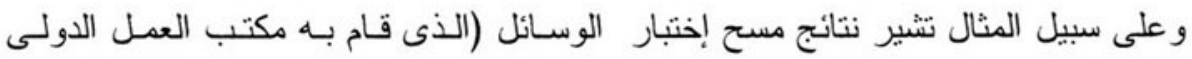

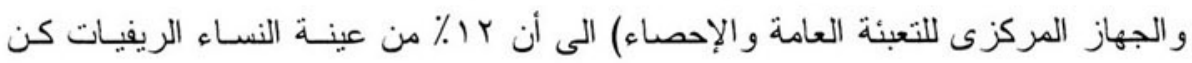

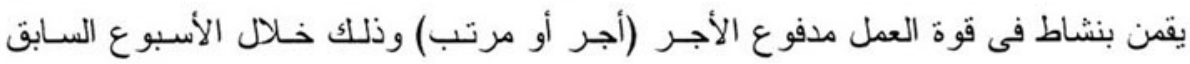

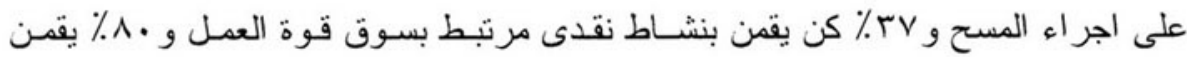

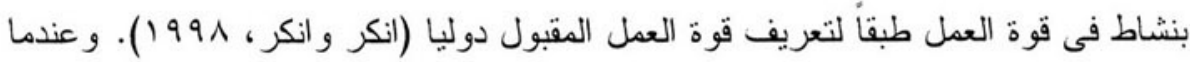

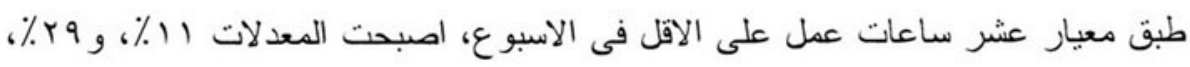

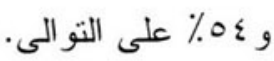

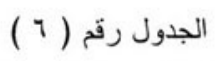

تطور المساهمة فى قوة العمل و البطالة

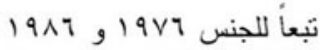

\begin{tabular}{|c|c|c|}
\hline \multicolumn{2}{|c|}{ معدلات المساهمة فى قوة العمل ( rا سنة فاكثر ) } & 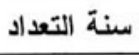 \\
\hline إناث & ذ نكور & \\
\hline $7, r$ & $v \varepsilon, r$ & $19 \vee 7$ \\
\hline 9,7 & $v_{\cdot, 0}$ & 1917 \\
\hline \multicolumn{2}{|c|}{ معدلات البطالة ( r ا سنة فأكثر ) } & \\
\hline إناث & ذكور & \\
\hline ri,r & $\varepsilon, 1$ & $19 \vee 7$ \\
\hline$r \varepsilon, 0$ & 10,0 & 1917 \\
\hline
\end{tabular}

المصدر : الجهاز المركزى للتعبئة العامة والإحصاء ، تعداد 19v7 و 1919 1 .

ومعدلات البطاله بين الاناث أعلى من معدلاتها بين الذكور ، بالر غم من انخفاض فجوة النوع فى البطالة عن مستويات 9 ا 19 ، بسبب الزيادة النسبيه الكبيره فى البطلة بين الذكور (نـوار ، 1991). وتقول ابر اهيم (1911) انـه يجب اعطـاء اهتمـام اكبر لطلب النساء المتز ايد على العمل فى الوظائف الرسميه، كما اتضـح فى زيـادة معدلات البطالـة 
وفى النسبة العالية للاناث المنقدمات للعمل فى المصانع (بابـانك و ابر اهيم، ب.، ب 91 )، مقابل المستويات المنخفضة المذكورة لمساهمة الاناث فى العمل . وخلافاً للنمط السائد بين الذكور المصريين، فان مساهمة الاناث فى قــوة العمل،

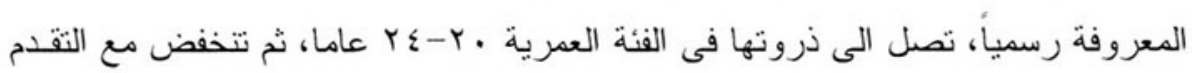

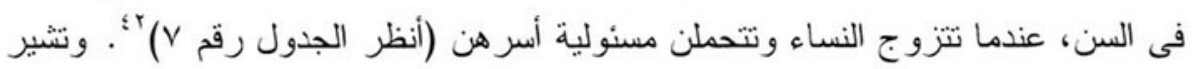

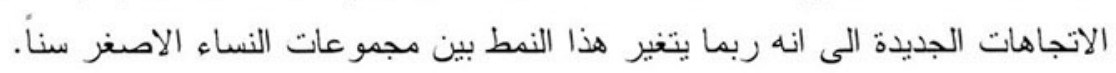
وتحدث الزيادة الاكثر اثارة فى مساهمة النساء فى قوة العمل، خـلال السنوات

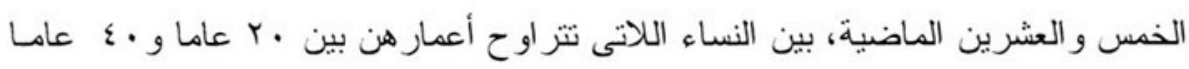

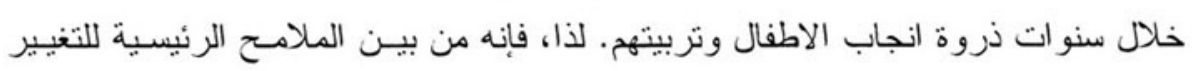

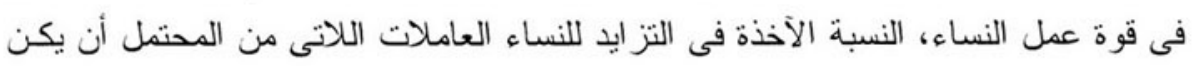

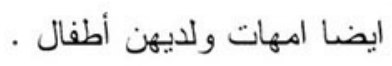

و نظر أ لأن مسـاهمة النسـاء الماليـة فى المـنزل حـافز رئيسى لدخولهن سـوق

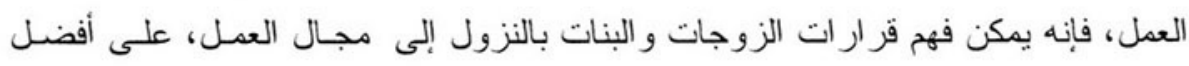

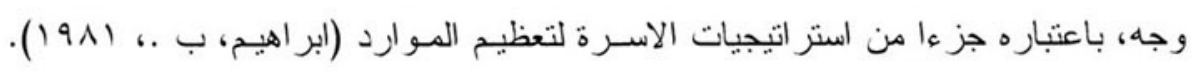

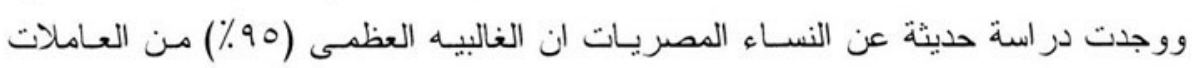

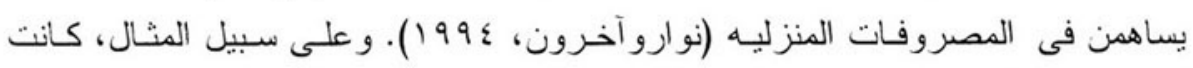

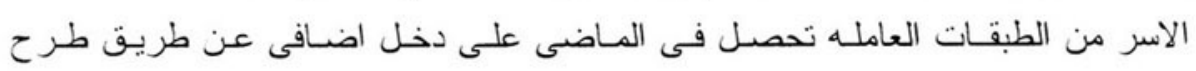

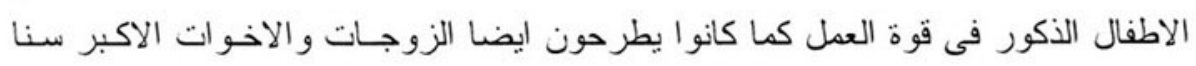

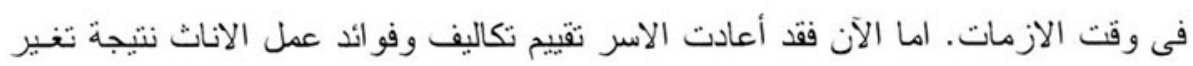

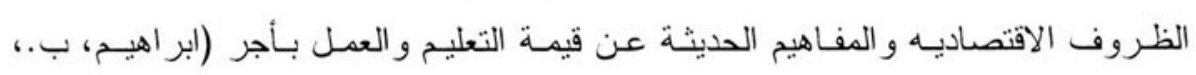
. (191) 


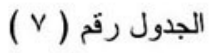

تطور معدلات المساهمة فى قوة العمل

\begin{tabular}{|c|c|c|c|c|c|c|}
\hline \multicolumn{3}{|c|}{ الذكور } & \multicolumn{3}{|c|}{ الإحاث } & \multirow{2}{*}{ السن } \\
\hline 1917 & 1987 & $19 \%$. & 1914 & 1987 & 197. & \\
\hline$\varepsilon, 9$ & $r \cdot, \Lambda$ & $1 \varepsilon$ & $1, r$ & $97, \wedge$ & $0, r$ & $9-7$ \\
\hline 11,9 & $r \cdot, \cdot$ & $r \wedge, \varepsilon$ & 1,7 & 0,0 & $9, v$ & $1 \leqslant-1$. \\
\hline$\varepsilon \cdot, r$ & $\varepsilon 9,9$ & $7 \wedge, \varepsilon$ & $v, r$ & 0,1 & $\Lambda, 7$ & $19-10$ \\
\hline$v 9,9$ & $v 1, v$ & $\wedge \uparrow, 1$ & $r \cdot, 0$ & $1 r, \varepsilon$ & $v, r$ & $r \varepsilon-r$. \\
\hline $90, \varepsilon$ & $9 r, 9$ & 97 & $1 V, 7$ & $1 \cdot, \wedge$ & $\varepsilon, \wedge$ & $r q-r_{0}$ \\
\hline $97, V$ & 9V & $9 \vee, \wedge$ & $1 \varepsilon, 9$ & $\vee, \wedge$ & $\varepsilon, 0$ & $r \varepsilon-r$. \\
\hline $9 \vee, r$ & $9 \wedge, r$ & $9 \wedge, 1$ & 9,1 & 0,0 & $\varepsilon, \varepsilon$ & rq-ro \\
\hline $90, Y$ & $9 \vee, 9$ & $9 \vee, \mathrm{V}$ & $\wedge, r$ & $\varepsilon, r$ & $0, r$ & $\varepsilon \varepsilon-\varepsilon$. \\
\hline $9 \varepsilon, r$ & $9 \wedge, r$ & $9 \vee, V$ & 7 & $r, 0$ & $\varepsilon, \varepsilon$ & $\varepsilon q-\varepsilon 0$ \\
\hline $91, r$ & 97,1 & $97, r$ & $\varepsilon, r$ & $r, r$ & $\varepsilon, 7$ & $0 \leqslant-0$. \\
\hline$\wedge \wedge, \wedge$ & $90,$. & $9 \varepsilon, 0$ & $r, \varepsilon$ & $r, v$ & $r, \varepsilon$ & $09-00$ \\
\hline $7 \wedge, r$ & $\vee \mathrm{V}, \Lambda$ & $\wedge 0, r$ & $r, \cdot$ & $r, r$ & $r, r$ & $7 \varepsilon-7$. \\
\hline Yo,o & $\varepsilon \cdot, q$ & $7 r, 0$ & $\cdot, \mathrm{v}$ & 1,1 & 1,9 & 7 فأكثر \\
\hline$\varepsilon \wedge, r$ & or, v & $7 \wedge, r$ & $7, r$ & 0,0 & 0,9 & الإجمالى \\
\hline
\end{tabular}

$$
\begin{aligned}
& \text { حسب السن و النوع } \\
& \text { سنو ات مختارة } \\
& 1917 \text { - } 197 .
\end{aligned}
$$

وبالر غم من دخول النساء المصريات الى مجال العماله الرسمية، فـأن تجربتهن مع "التحرير" و الحقوق المكتسبة حديثا قد أصبحت محفوفة بالصر اعـات و اكثر تعقيدا. و أجبر هن الافتقار الى خدمات المساعدة، بما فى ذلك دور رعاية الاطفـال واصـر ار القيم

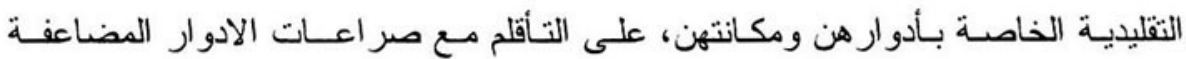
و المتعددة و الزيادة فى عبء العمل (عبد القادر ، .99 (1) ) .

ولم تتأثر كل النساء العاملات بهذه الصر اعات و الزيادة فى عبء العمل. فالنساء المتعلمات من الطبقات العليا فى المنــاطق العضريـة يحصلـن على المسـاعده الاجتماعيهـ نتيجة وظائفهن المجزية التى انتشرت بسبب سياسة الانفتاح الاقتصادى التى بدأها الرئيس السادات. كما ان هؤ لاء النساء يحصلن على مساعده منزلية مما لا يضاعف من واجباتهن

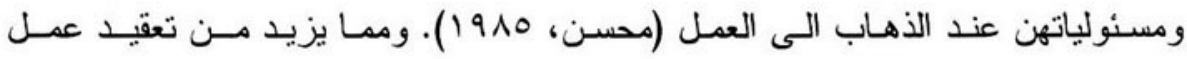
مجموعات اخرى من النساء الحضريات هو ضعف الحاله الماليـة التى لا تمكنهن من 
الحصول على مساعدة منزليـة وموقف الآبـاء و الازواج المتتـاقض تجـاه عمل زوجـاتهم

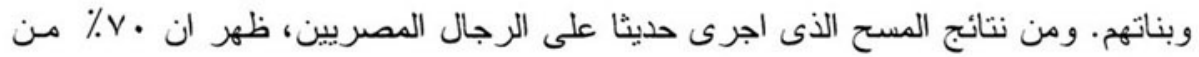

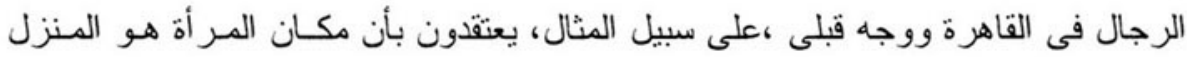
و لا يجب عليها العمل. وكانت هناك اختلافات طفيفه فى هذه الار اء وفقا للسـن و المسـتوى

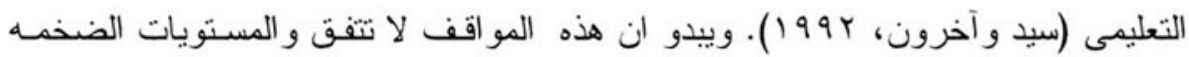

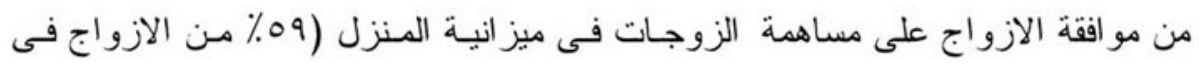

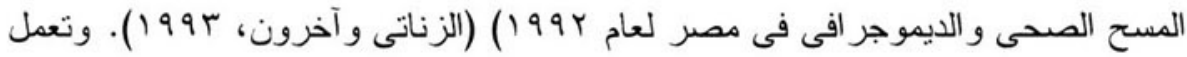
الكثير من النساء المتعلمات من الطبقات الدنيـا فى المنـاطق الحضريـة في في القطـاع العـام

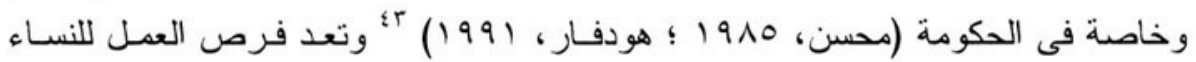

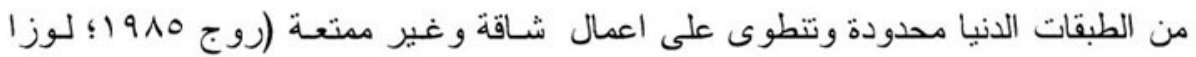
. (19^^

و المشكله الرئيسية التـى تواجـه هذه النسـاء هـى استمر ار مسئولياتهن بالنسبة لر عاية الاطفال و العمل المنزلى. وكما أسلفنا آنفا، لا يمنلك هؤلاء النســاء الموارد الكافيـة

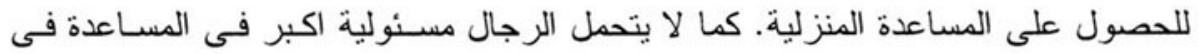

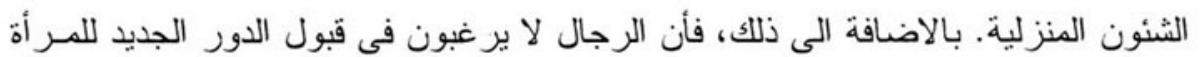

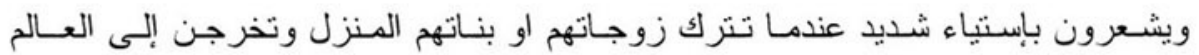

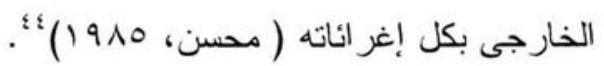

أما النساء المنذرطات فى العمـل غير الرسمى فموقفهن مختلف. فعلى سبيل

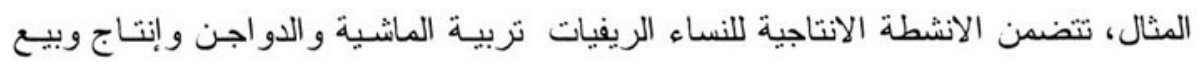
منتجات الالبان و العمل الموسمى فى الار اضى الزر اعية (الجهاز المركزى للتعبئـة العامـة

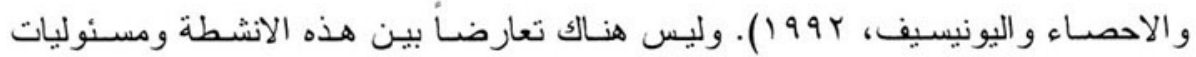

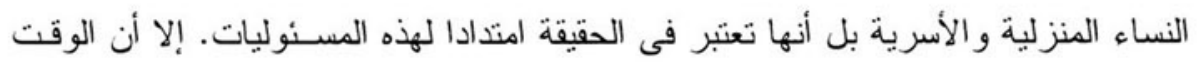
و المجهود البدنس المطلوب لإداء مثل هذه الانشطة مضن. وقد وصفت إحدى النسـاء

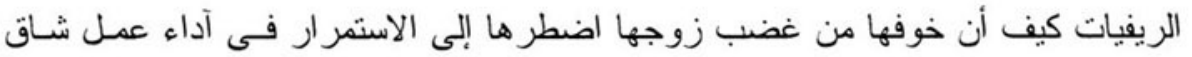

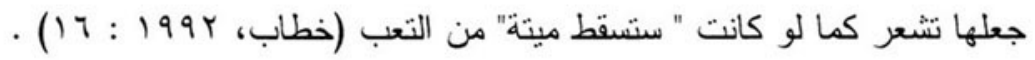




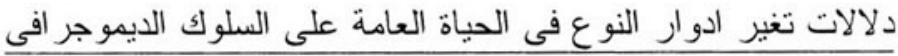

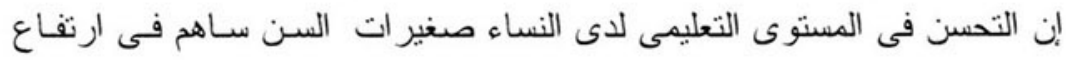

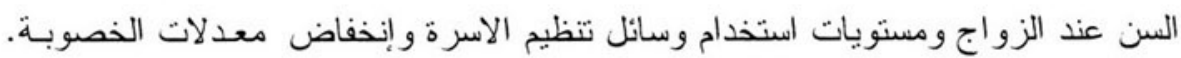

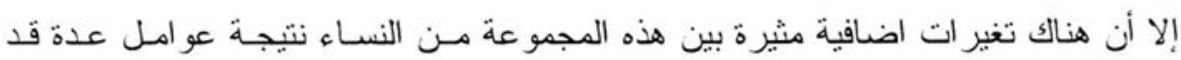

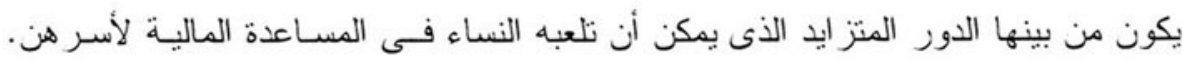

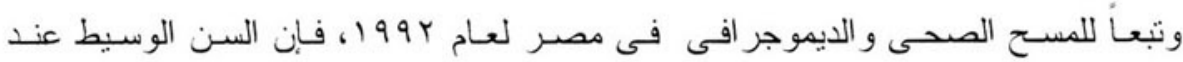

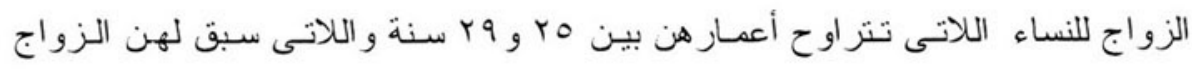

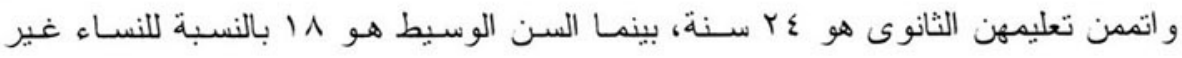

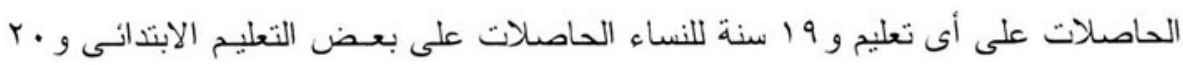

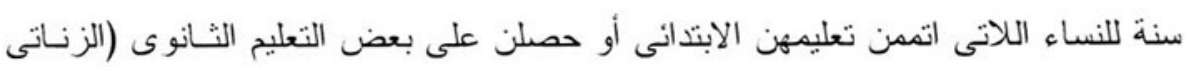

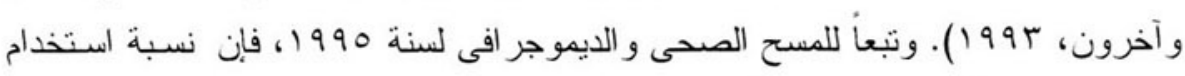

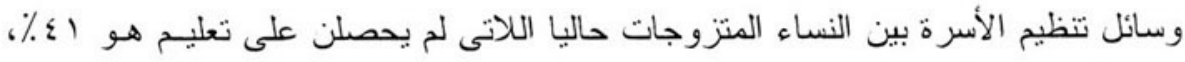

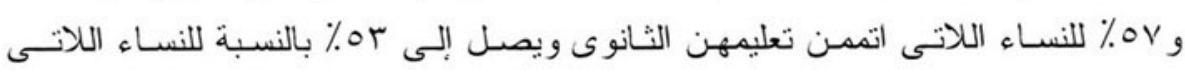

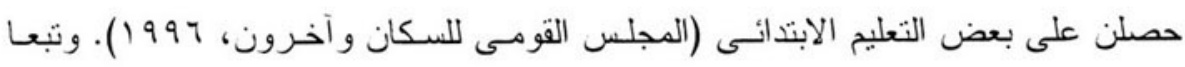

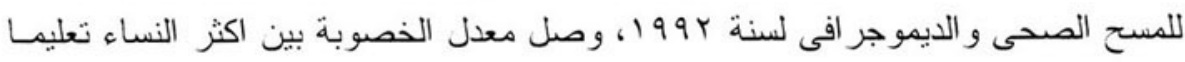

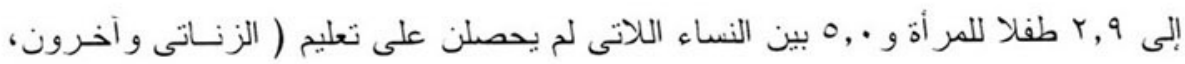

\section{ومن المكن أن تكون تكاليف الاطفـال باهظة بالنسبة للنسـاء المنذرطسات فى}

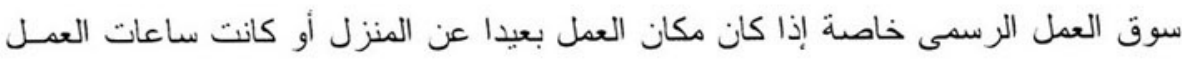

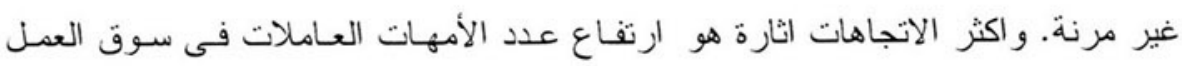

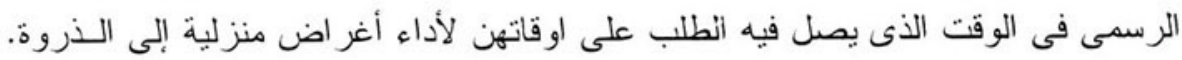

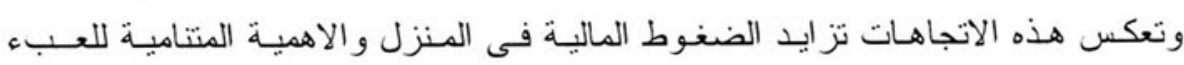

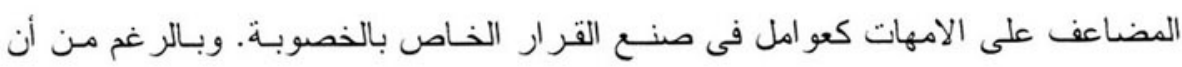

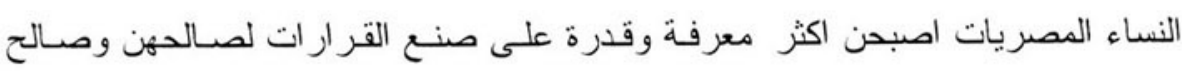

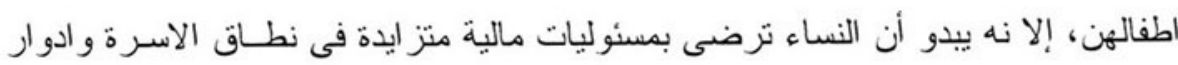

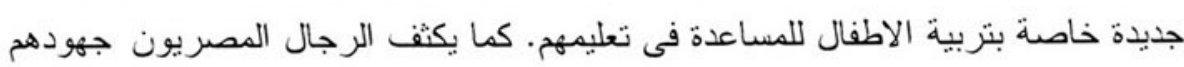

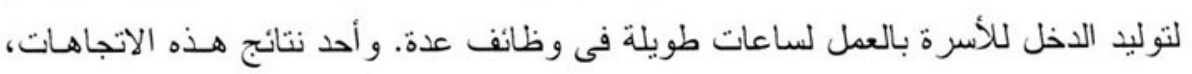


خاصة فى المناطق الحضرية، هو تفضيل عدد أقل من الاطفـال ويظهر ذلك بجـلاء فى

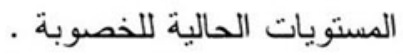

وبالر غم من أن نسبة صغيرة من النساء المصريـات مسـجلات رسميا كعـاملات

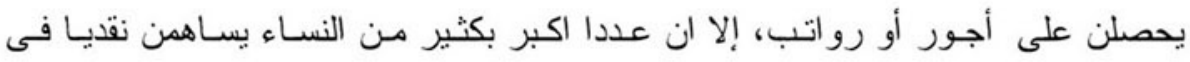

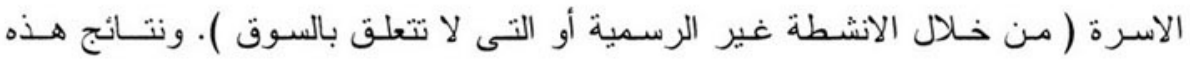

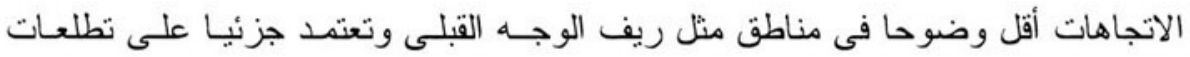
الأباء لتحسين نعليم ابنائهم وصحتهم وقدرتهم على العمل لتحقيق هذه التطلعات . .

\section{اوجه عدم المساواه فى النوع فى تقديم خدمات الصحة الانجابية :} تستطيع النساء فى مصر أن تحصـل على رعايـة حديثة للصدـة الانجابيـة مـن

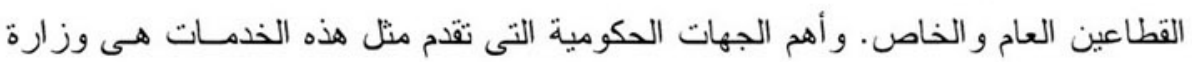
الصحة و السكان التى تدير شبكة تتكون من حوالى . . . منفذ لتقديم خدمة تنظيم الاسرة،

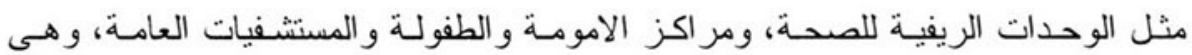

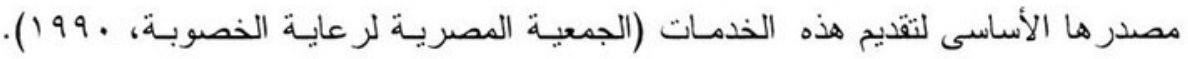

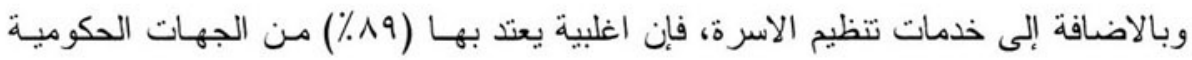

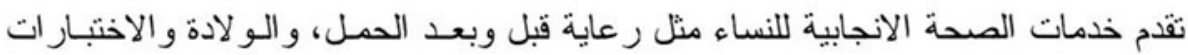

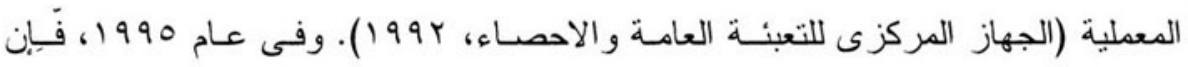

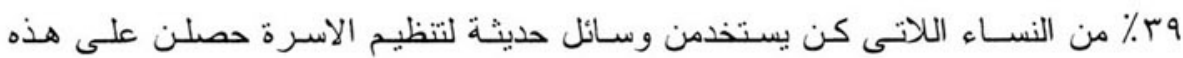

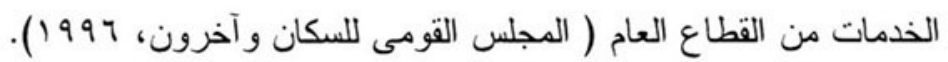

و لا توجد معلومات كافية عن توفر خدمات الصحة الانجابية للرجال فى الجهات

الحكومية التى تقدم الذدمات الاساسية للرعاية الصحية. وبما أن رعاية الصحسـة الانجابيـة

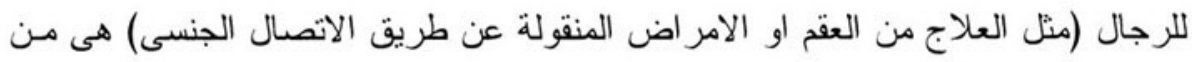

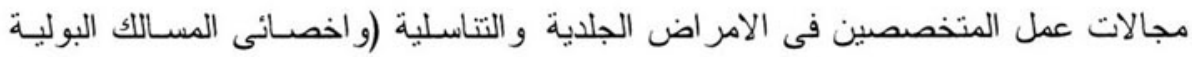
بدرجة أقل) فى مصر ، فإن مثل هذه الرعاية للرجال التى تقدمها نظريا الجهات الحكوميـة

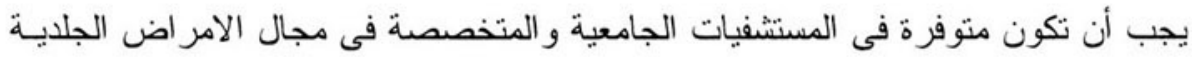
و التناسلية التى نتوفر عادة فى المدن الكبرى . 
و هنـاك شكاوى مـن نو عيـة الخدمـات التى تقدمهـا الوحسـدات الصديـة الريفيـة

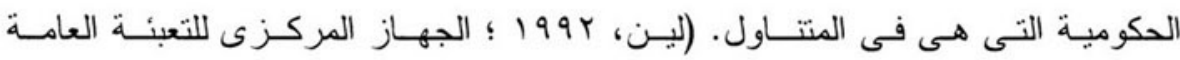

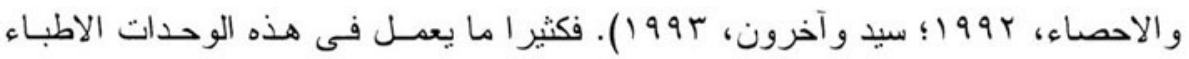

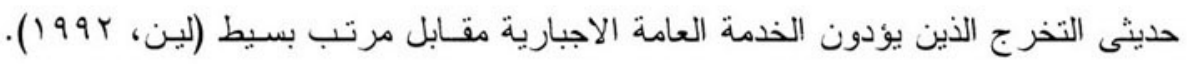

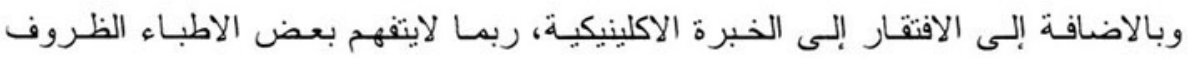

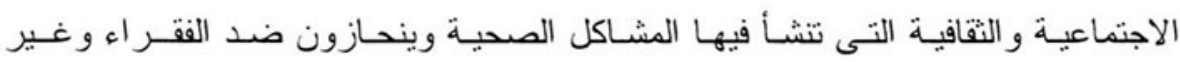

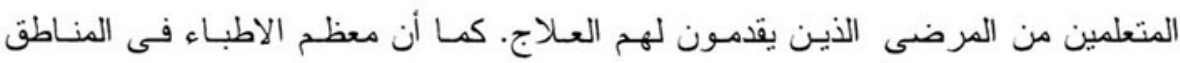

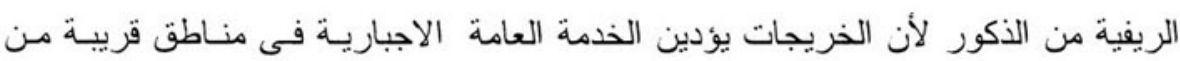

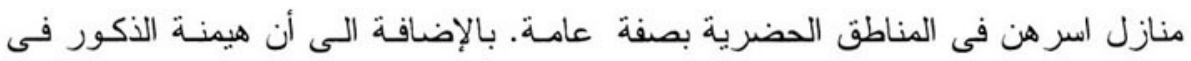

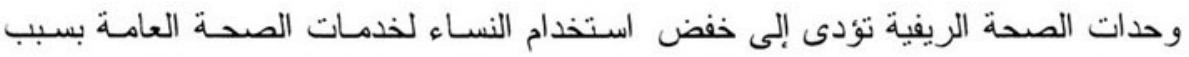
الإلتز ام بقو اعد الحباء والاحتشام وتفضيل النساء الريفيات التعامل مع الطبيبات . .

ونتيجة للنظرة السائدة لنوعية خدمات الصحسة العامـة على أنها متدنيـة، يسعى

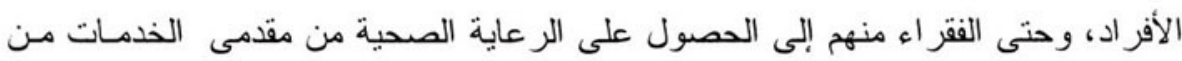

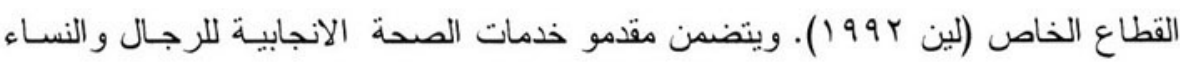

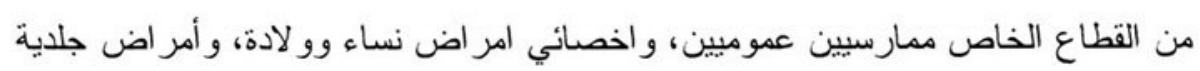

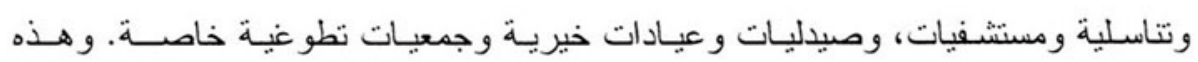

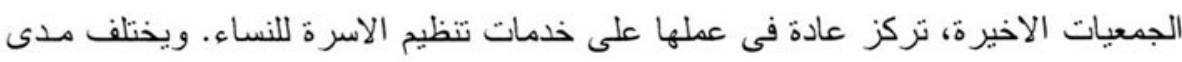

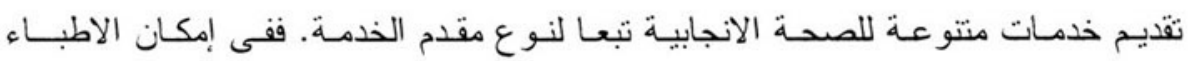

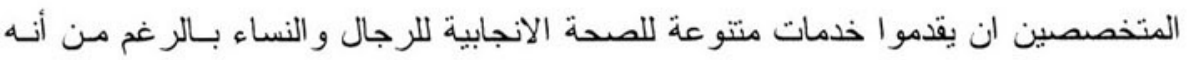

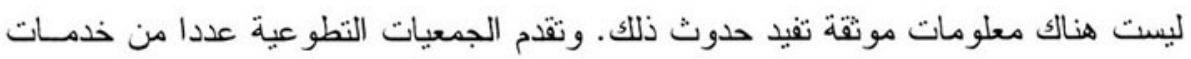

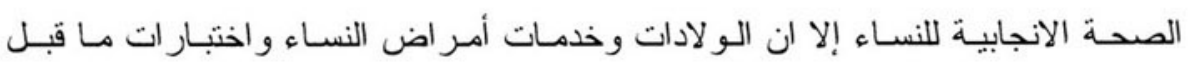

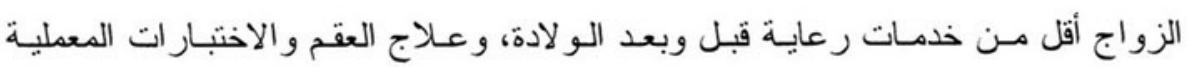

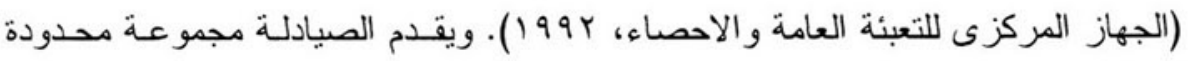

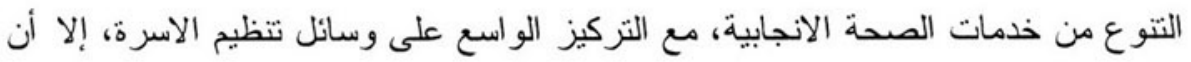
هذه الوسائل رائجة بين المستخدمين .

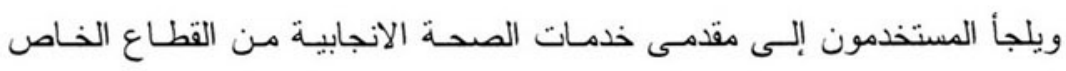
الحديث للحصول على خدمات تنظيم الاسرة أكثر مـن لجونهم الى مقدمى الخدمـات مـن 
القطاع العام. وفى عام 1990 حصلت . ٪\% من النسـاء اللاتى كن يستخدمن فى ذلك

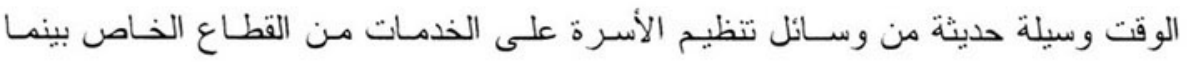

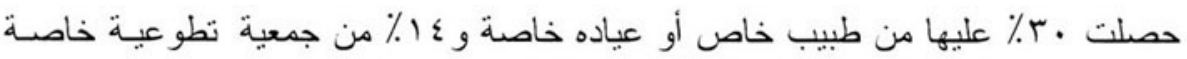
و 7 ٪ من الصبدلية (المجلس القومى للسكان و آخرون، 999 ( ).

ونتوفر فى مصر نو عبـة محدودة مـن وسـائل تنظيم الاسرة مـع التركيز على

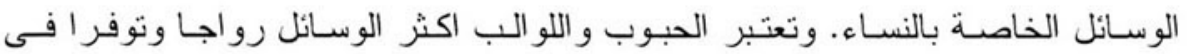

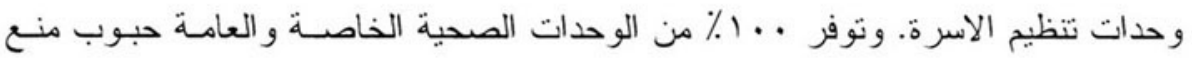

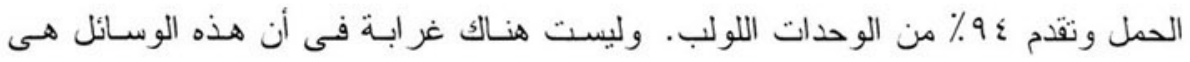
ايضا اوسع وسائل نتظيم الاسرة استخداما. وتعزى كل الزيادة فى اســخدام وسـائل تنظيم

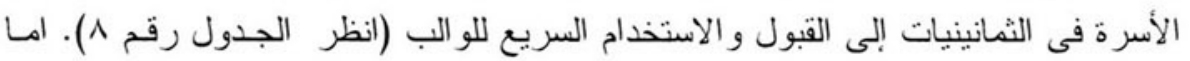

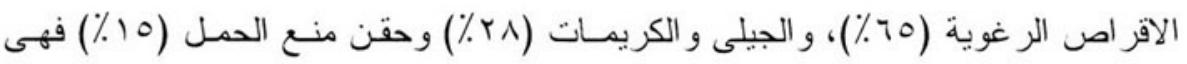

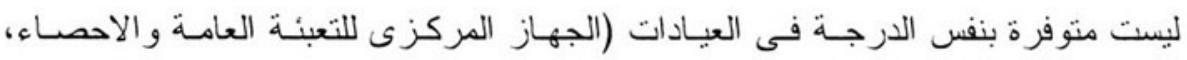

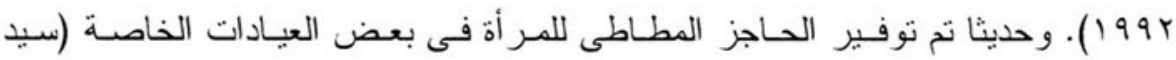
و آخرون، بو9 (1) ). وبإستثناء الحبوب و اللو الب، فإن استخدام كافـة وسـائل تنظيم الاسـرة

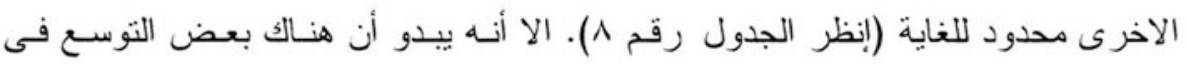

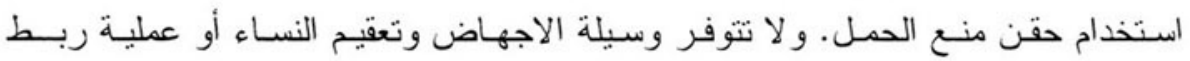

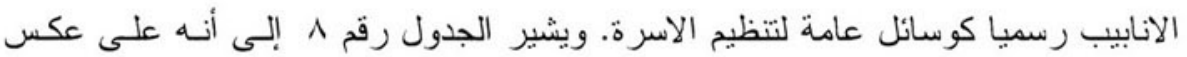

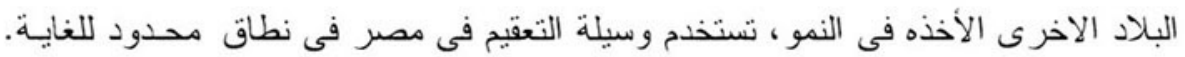

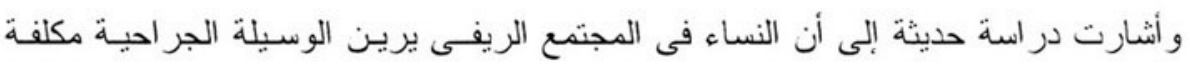

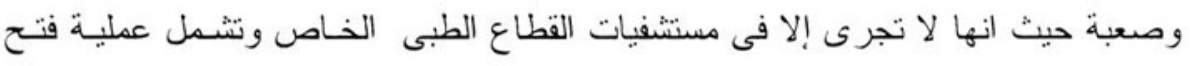

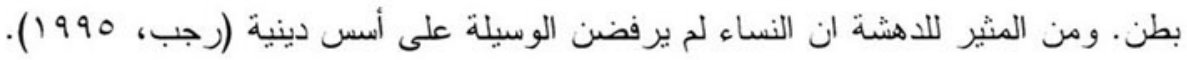

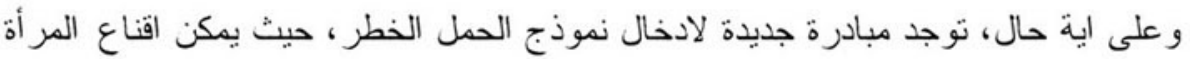

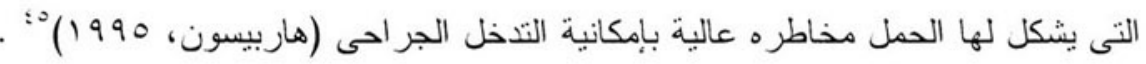
ويعتبر الاجهاض المتعمد غبر قانونى فى مصر إلا إذا كان سببه المحافظة على

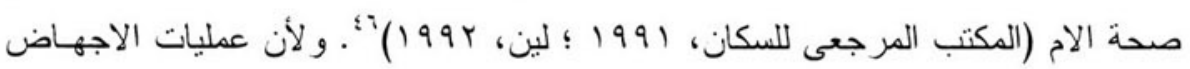

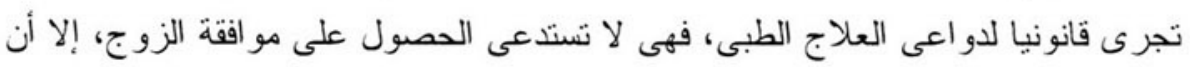

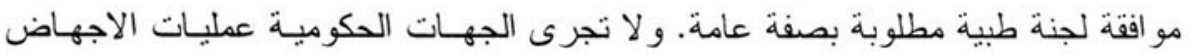


لذا فهى متوفرة فقط فى الجهات الخاصـة. و وعلى سبيل المثال فـان المكتب المرجعى

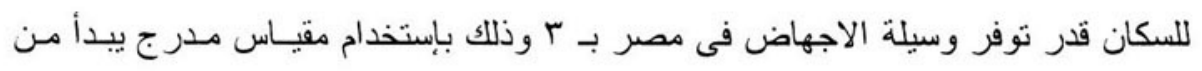

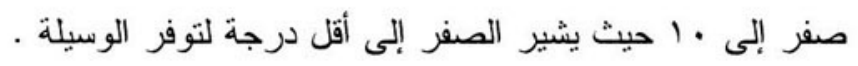

وبالر غم من عدم قانونية الاجهاض رسميا، فإن الجهات المفوضة بتنفيـذ القانون لا تتعقب انتهاكات القانون. وترى الحكومة أن الاجهاض مسألة خاصة لا تستدعى التدخل

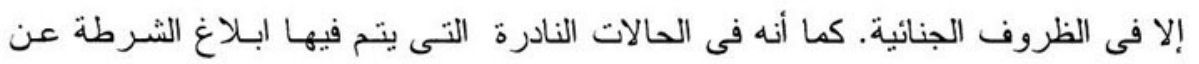
عملية اجهاض، يصبح من الصعب رفع دعوى ناجحة ( محسن، . 199 (1) . و الموقف السلبى الذى تتبنـاه جهات تنفيذ القانون يبدو متفقـا مـع الخيـار ات المطروحة فى القانون الاسـلامى اكثر مـن اتفاقـه بـالفعل مـع القـانون المصـرى الحـالى.

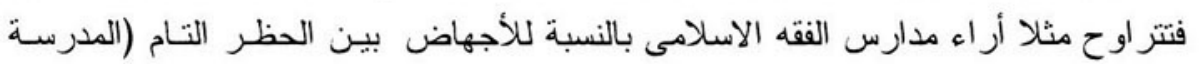

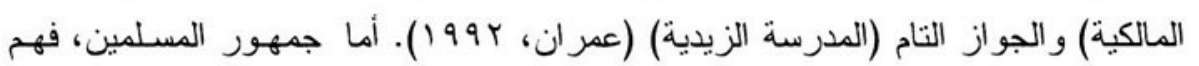

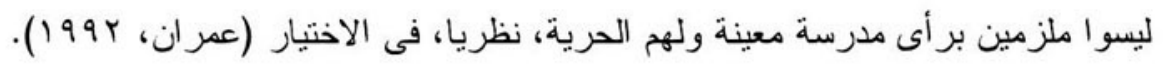

وكثير ا مـا يكون القـانون و الممارسـة أمريـن مختلفين. وتلجـأ كثير مـن النسـاء

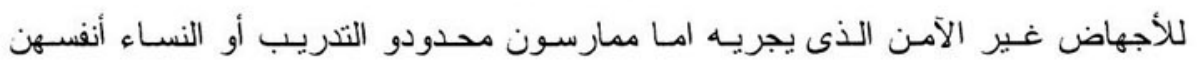

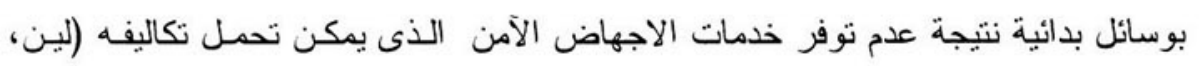

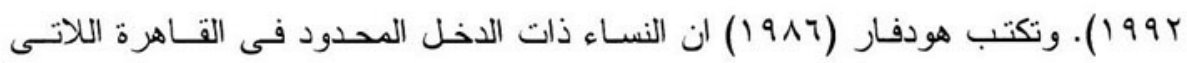

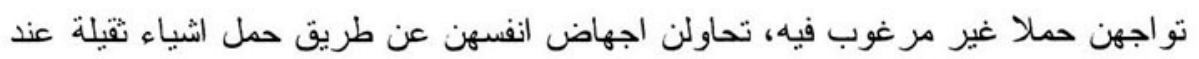

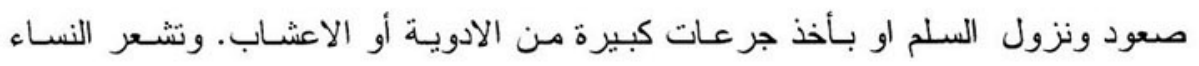

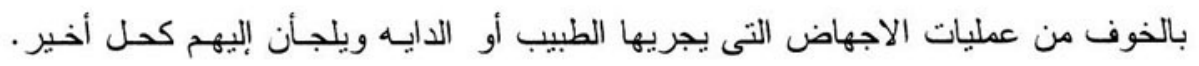

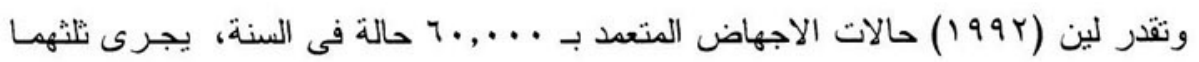

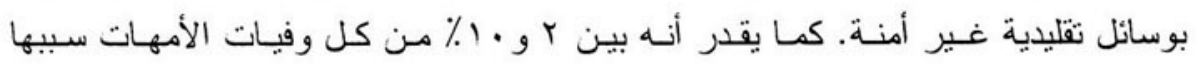

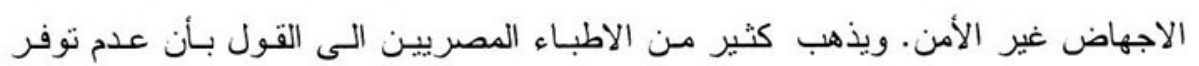

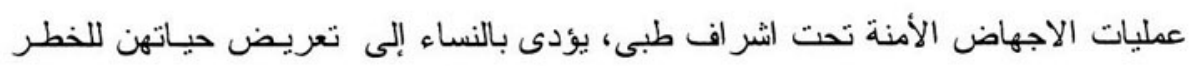

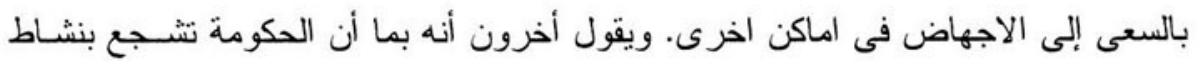

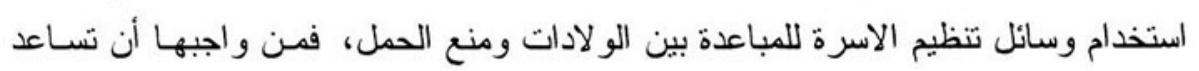


هؤلاء النسـاء اللاتـى تتعر ضـن لفشـل وسـائل تنظيم الاسـرة المقدمـة مـن خـلال بر امــج

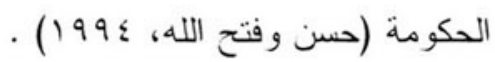

واحدى الوسائل الاخـرى التى لا يـروج لها رسميا كوسيلة مـن وسـائل تنظيخ

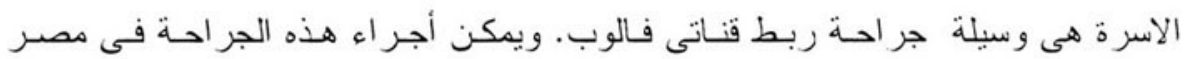

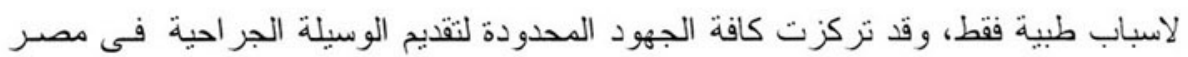

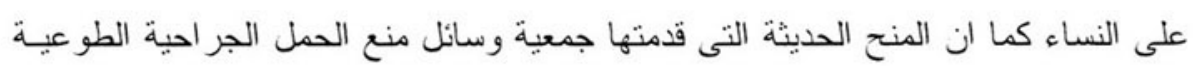

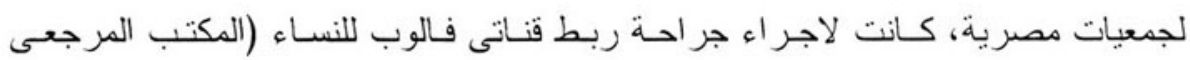

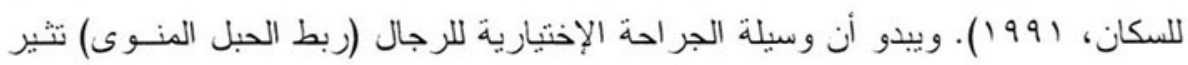

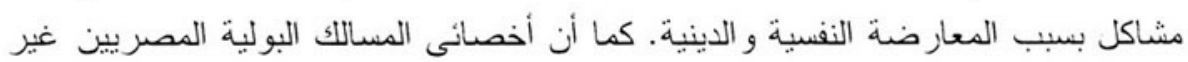

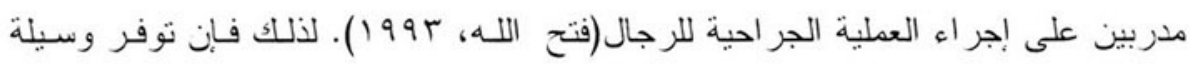

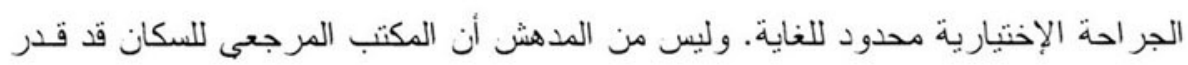

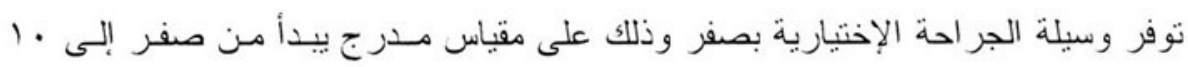

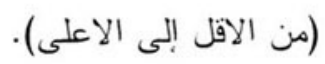

وتنبع المعارضة الدينية لوسيلة الجر احة الإختيارية من الر أى السائد بـأن التعقيم

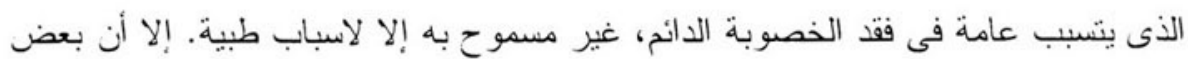

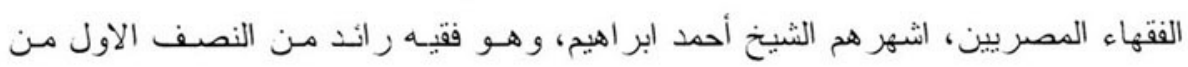

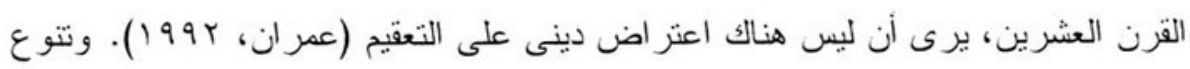

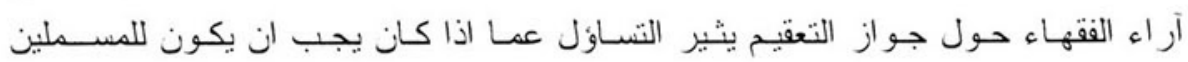
الاختيار الفردى فى هذا الثأن. وتسمح بعض البلاد الاسلامية الاخرى مثل تونس وتركيـا و اير ان بوسيلة الجر احة الإختيارية وينتشر عندهم وسيلة تعقيم الاناث بمعدلات عالية. 


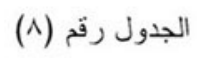

التوزيع المنوى للمستخدمين الحاليين

لوسائل نتظيح الاسرة حسب نوع الوسيلة

\begin{tabular}{|c|c|c|c|c|}
\hline $\begin{array}{l}\text { EDHS } \\
1990\end{array}$ & $\begin{array}{l}\text { EDHS } \\
19 ৭ \mathrm{r}\end{array}$ & $\begin{array}{c}\text { EDHS } \\
19 \wedge \wedge\end{array}$ & $\begin{array}{l}\text { ECPS } \\
19 \wedge £\end{array}$ & 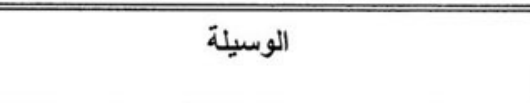 \\
\hline $90, \cdot$ & 90,1 & $9 \mathrm{gr}, \mathrm{V}$ & $9 \leqslant, V$ & أى وسيلة حديثة \\
\hline$r, \wedge$ & $r v, \varepsilon$ & $\xi \cdot, r$ & $0 \leqslant, 0$ & 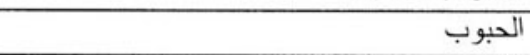 \\
\hline $7 r, V$ & $09, r$ & $\$ 1,0$ & $r v, v$ & 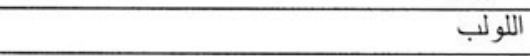 \\
\hline $0, \cdot$ & 1,1 & $\cdot, r$ & $1, \cdot$ & حقن منع الحمل \\
\hline$\cdot, \cdot$ & $\because, \cdot$ & $\because \cdot$ & $\cdot, \cdot$ & كبسو لات النوربلانت \\
\hline$\cdot, \mathrm{r}$ & $\cdot, \wedge$ & 1,1 & $r, r$ & الحاجز المطاطى- الأقر اص الرغوية و الجيلى \\
\hline$r .9$ & $\varepsilon, r$ & $7, r$ & $\xi, r$ & الو اقى الذكرى \\
\hline$r, r$ & $r, r$ & $\varepsilon, \cdot$ & $0, \cdot$ & تعقيم الإناث \\
\hline$\cdot, \cdot$ & $\cdot, \cdot$ & $\because \cdot$ & $\because, \cdot$ & تُعقيم الذكور \\
\hline $0, \cdot$ & $\xi .9$ & $7, r$ & $0, r$ & آية وسبلة تقليدية \\
\hline $1, r$ & 1.0 & 1,7 & $r, \cdot$ & وسبلة فترة الامان \\
\hline $1, \cdot$ & 1.0 & $1, r$ & $1, \cdot$ & القذف بالخار ج \\
\hline$r, 1$ & 1,9 & $r, 9$ & $r, \cdot$ & الرضاعة الطبيعبة الممتدة \\
\hline$\cdot, r$ & $\cdot, r$ &., 0 & $\cdot r$ & وسائل أخرى \\
\hline $1 \cdots \cdot$ & $1 \cdots \cdot$ & $1 \cdots, \cdot$ & $1 \cdots, \cdot$ & اجمالى النسبة المنوبة \\
\hline
\end{tabular}

ملحوظة : لا تصل النسبة المئوية الفردية عند جمعها إلى ل. 1 بسبب الثتريب.

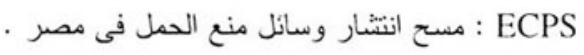

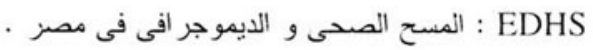

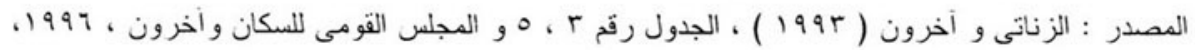

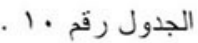

وعلى الرغم من ان القانون لا يشترط الحصول على موافقة الزوج مـن اجل

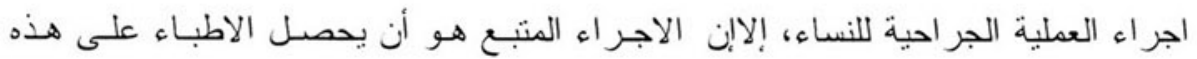

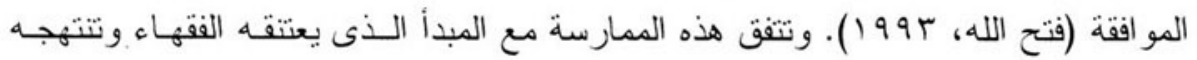

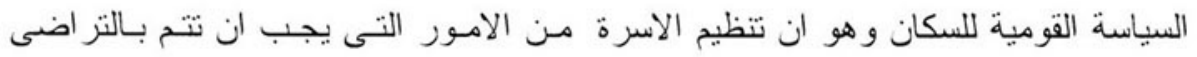

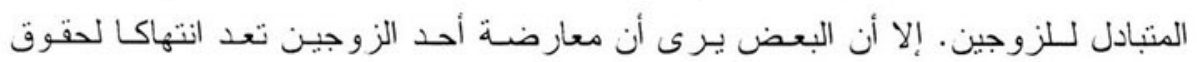
الانسان التى نتضمنها الدساتير الوطنية والاتفاقات الدوليـة لحقوق الانسـان (كوك وميـن.

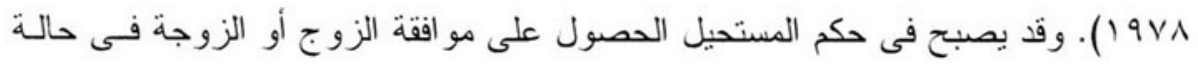
الانفصال أو لأى ظرف طارئ. 
ويبدو أن عدم انتشار وسيلة تعقيم الاناث تتبع من محدوديـة توفرهـا وليس عدم وجود اهنمام بها. وتزى حو الى نصف النساء المصريات اللاتى على دراية بوسائل نتظيم

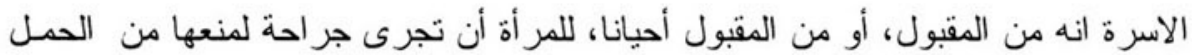
مرة ثانية، على أن يكون لديها العدد الذى ترغبه من الاطفال وأن يو افق زوجها على ذلك هلك

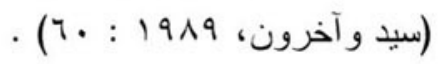

و هناك عدة مظاهر مثيرة للإهتمام خاصة بهذه المواقف. اولا: أنها تتعارض مـع

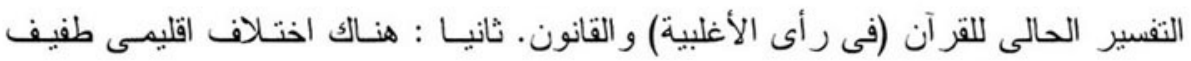

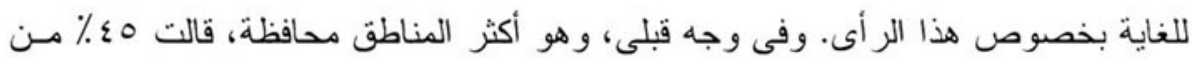

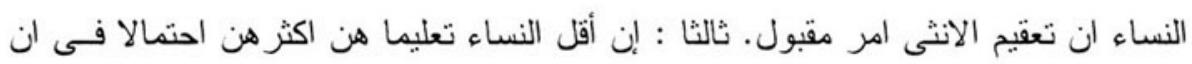

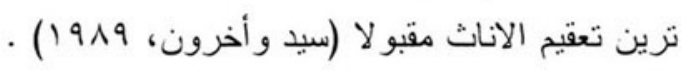

و الوسيلة الوحيدة لتنظيم الاسرة التى تخص الرجال المتوفرة حاليـا هـى الواقى الذكرى. وبالر غم من ان هذه الوسيلة منوفرة بصـورة واسعة في وحسدات تنظيم الاسرة

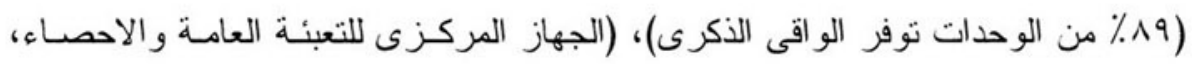

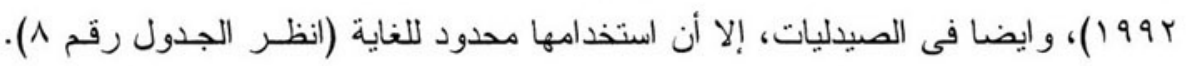

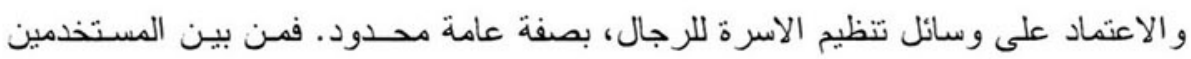

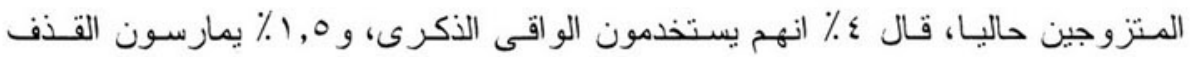
بالخارج، بينما لا يستخدم احد وسيلة تعقيم الذكور ــ ولا يؤيد الذكـور المصريـون استخدام

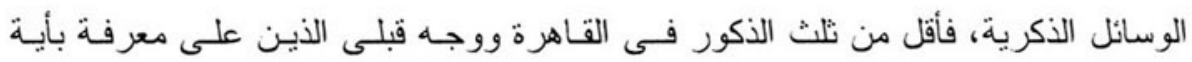

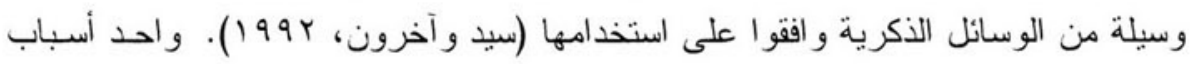

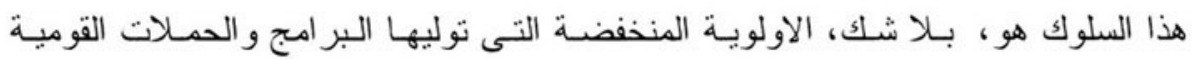

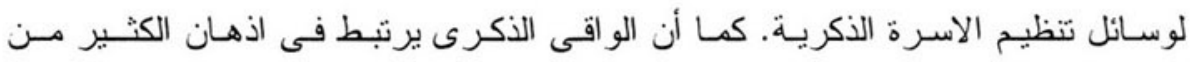

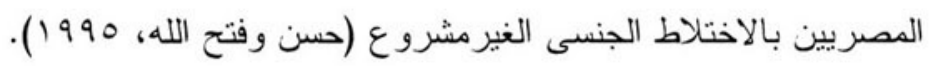

وبـالر غم من ان الرجـال المصريين يتحملون مسئولية محدودة في الاستخدام الفعلى لوسائل تنظيم الاسرة، إلا انهم يشتركون فى مظاهر أخـرى لنتظيم الاسرة. فـأكثر

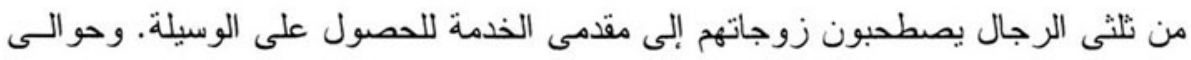


نصف الذين سبق لهم استخدام الوسائل حصلو ا عليها لزوجاتهم (سـيد وأخرون، ب99 ا ). وينم ذلك عن وجود فرص أخرى للأستعانة بالرجال فى نتظيم فعال للأسرة .

وبالاضافة إلى الامور الخاصة بإختيار الوسيلة وتوفرهـا، فقد تم رصد عبوب

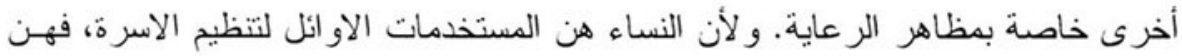

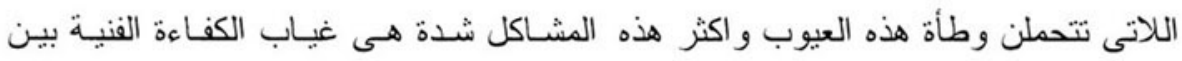

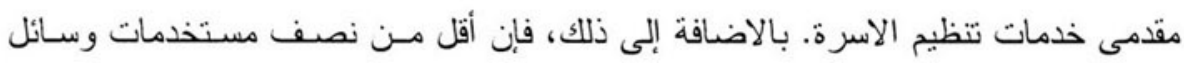

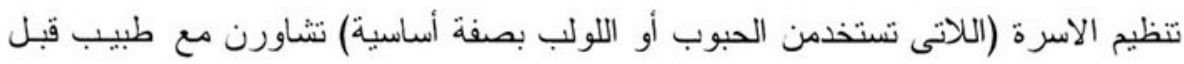

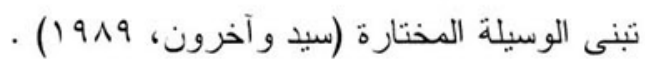

ولا يضمن التشاور مع الطبيب دائما حصول النساء على التقييم الطبى السليم. وقد صر ح اكثر من خمس المستخدمين الجدد في وحدات تتظيم الاسرة ان الطبيب لم يجر تقييمـا طبيـا لهـن قبـل وصف وسيلة لتنظيم الاسـرة (الجهـاز المركزى للتعبئـــة العامــة

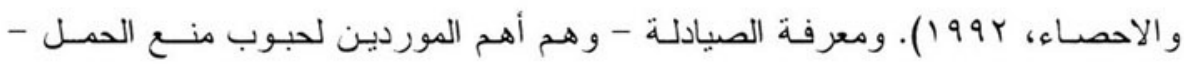
بالاستخدام الصحيح للحبوب نعانى من قصور كبير (سيد و آخرون، بو9 (1) ). ومن الثـائع

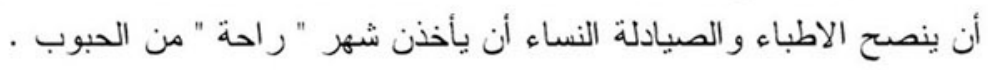

ولآن التنشئة الاجتماعية للنساء منذ الطفولة تحضهن على تحمل الالم الجسمانى

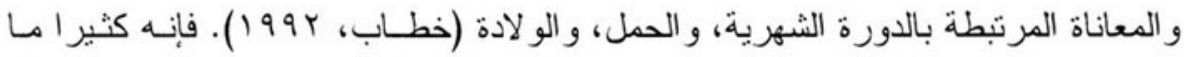

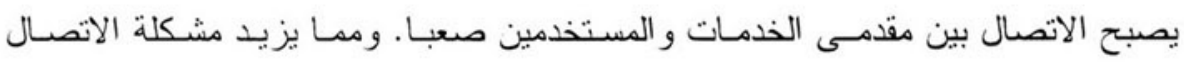

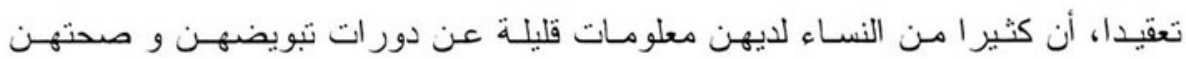
الانجابية؛". ونتيجة لذلك، يظهر العاملون فى حقل الصحة موقفا يتسم بالتعالى تجاه النساء

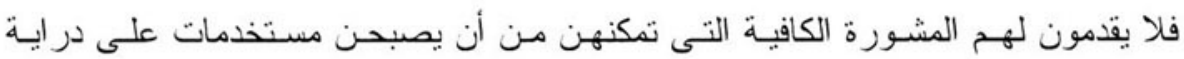
حقيقية بوسائل نتظيم الاسرة .

دلالات اوجه عدم الانصاف فى تقديم الخدمة على الاختيار الانجابى

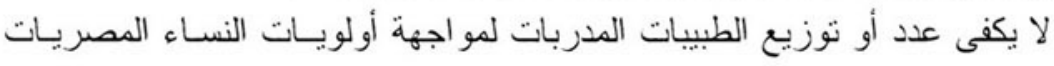
و هن المستخدمات الرئيسيات لوسائل تنظيم الاسرة فى الوقت الحسالى (الجهاز المركزى

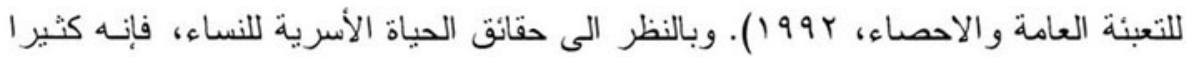

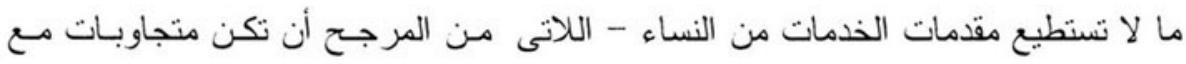


احتياجات النساء الانجابية وأن تشعر معهن النساء بالر احة عند مناقشة الامور الشخصبة

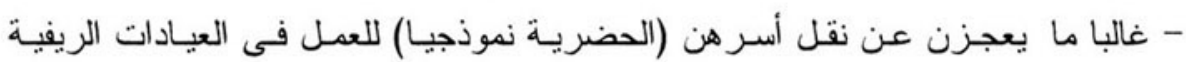

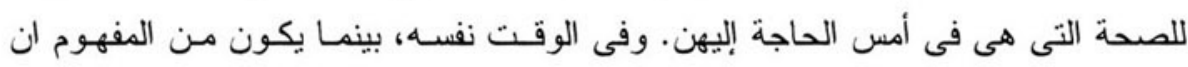

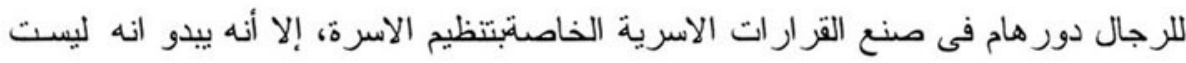

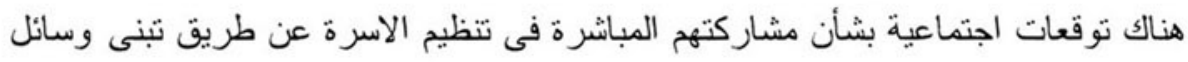

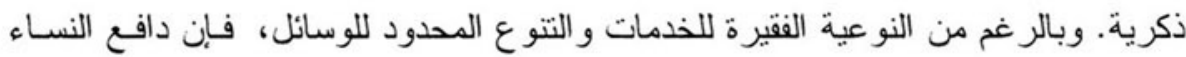

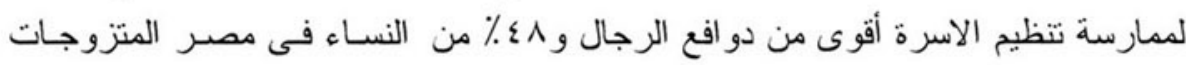

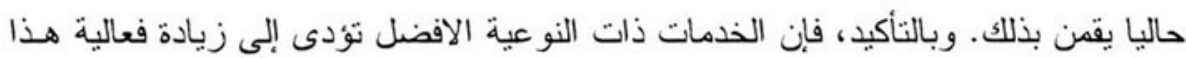

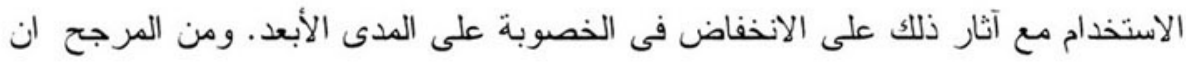
تجذب الخدمات المحسنة مستخدمين جدد او المسـتخدمين الذيـن لـم يستمروا فـى اسـتخدام الخدمة لان الخدمات القائمة لم تشجعهم على ذلك. ومن المرجح ايضا ان تؤدى المشـاركة

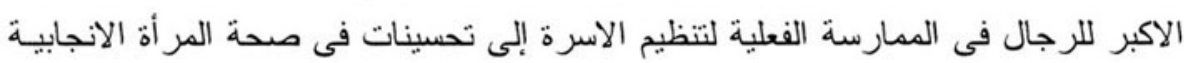

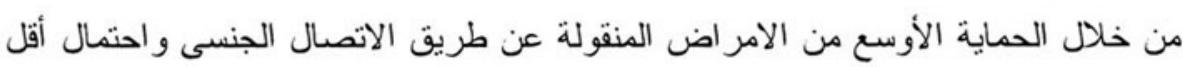

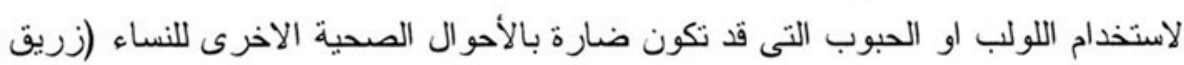

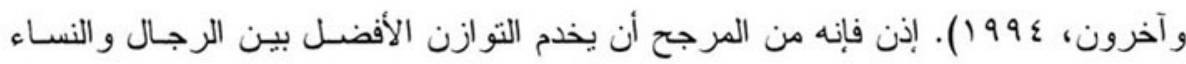
من بين مقدمى ومستخدمى الخدمات، مصالح النساء وأن تنشر مسـؤوليات ممارسـة نتظئم الاسرة بطريقة اكثر عدالة بين الاعداد المتتامية من الاسر التى ثرغب فى طفلين او ثلاثة يتمتعون بالتنشئة و التعليم الصحيحين. 


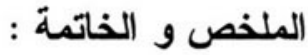

تظل الاسر من المؤسسات القوية والمتماسكة فـى المجتمع المصرى وذللك فى

غمرة التغيرات الاجتماعية و الاقتصادية و الديموجر افيـة السريعة. ويولد معظم الاطفـال المصريون وينشأون داخل هذا السياق الامن. وفى ظل هذا السياق ايضا يتم تعريف ادوار

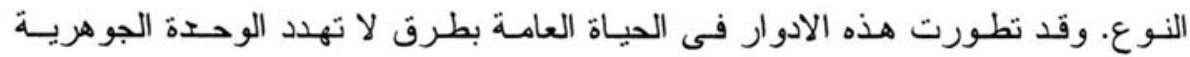

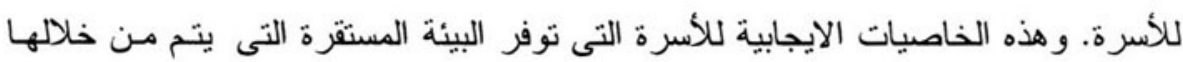
التخطيط لمستقبل معظم المصريين، تؤدى ايضلا إلى أوجـه معينـة لعدم المسـاو اة وقابليـة · النساء للأنجر اح و التأثر

وعندما قمنا بتحليل المناطق المثيرة للمشـاكل فى مجـال المعـيير و الممارسـات الخاصة بالنوع التى لها آثار على السلوك الديموجر افى، غالبا مـا نكون قد اعطينـا وزنـا للمعايير و الممارسات السلبية اكثر من الايجابية منهـا وذلك لاهتمامنـا فى نهايـة المطـاف بالسياسات. لذلك، فقبل الخوض فى بعض الآراء المتبصرة بشأن السياسات، نود أن نركز

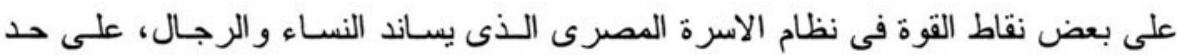
سواء، والذى ينبغى ان يسهل تحقيق الصحة والاختيار الانجابيين .

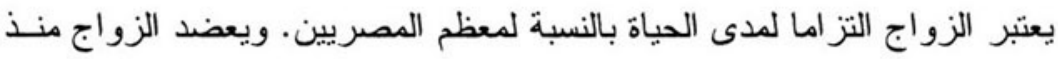

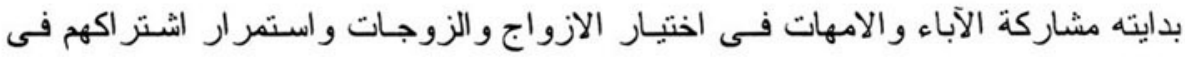
المر احل التالية عن طريق شبكة معقدة من الانظمة الاجتماعية و المؤسسية للمسـاندة تعمل ولاكل علىتغذية الزواج وديمومته. ولأن النساء والرجال يحصلون على المكانة الاجتماعية مـن

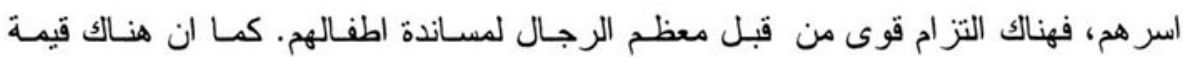
اجتماعية عالية مرتبطة بالأمومة. وغالبا ما تتضمن الادو ار المحددة بوضوح حبن بين الازواج

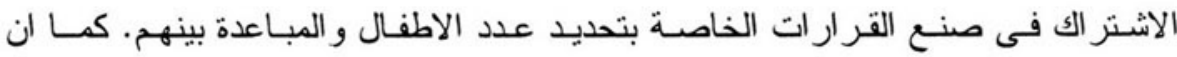
العقوبات المفروضة على تعدد الشركاء الجنسيين للنساء و الرجـال على حـد سواء، تبدو

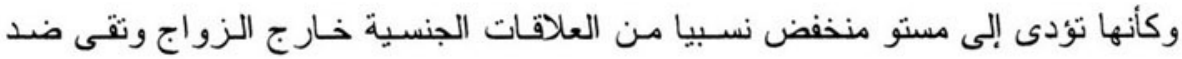
الانتشار السريع لمرض الايدز والامر اض الاخرى المنقولة عن طريق الاتصال الجنسى.

إلا ان هذا التقرير قد حدد فى عدة مجالات اخرى بعض العو اقب السلبية لانمـاط

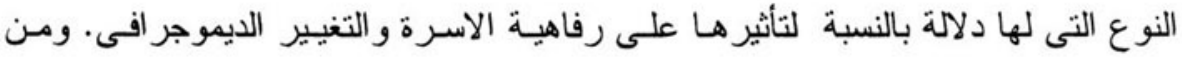


الممكن ان يركز صـانعو السياسـات و القـانونيون ومقدمو الخدمـات اهنمـامهم ومواردهـم

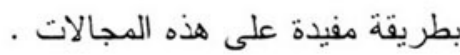

وتعانى النساء داخل الاسرة من عدم النساوى فى القانون وفى الو اقع على حد

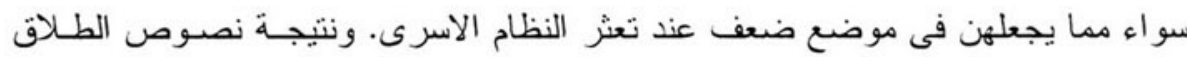
التى لا تتسم بالانصاف، و امكانية زو اج الرجل مـن اخرى و الاختلافـات فى التـأهيل فى ولى النصوص الخاصة بالمير اث وحضانة الاطفال، تو اجه النسـاء مخـاطرة ان تجدن انفسهن بدون مساندة الاسرة الاجتماعية و المالية بينما يتحملن فـى الوقت نفسـه مسئوليات اسرية

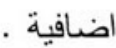

وبينما يمد الاستعمال الواسع لعقد الزواج النساء، نظريا، بالسبل القانونية لحمايـة

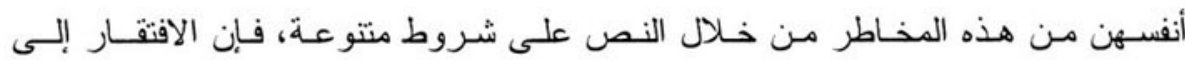
المعلومات و التحفظ تجاه خلط المفاوضات القانونية بإحتفالات الزواج قد ترك النساء بـدون

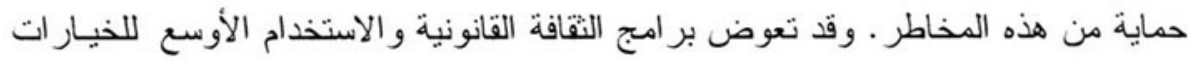

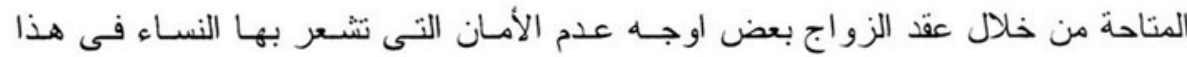

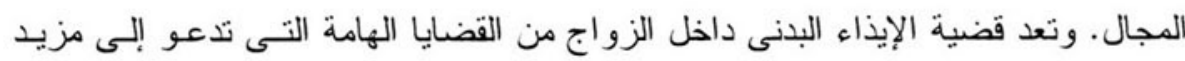

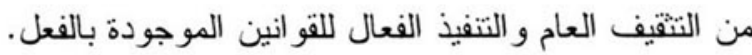

وتختلف السلطة و عملية صنع القرار فى نطاق الزو اج بدرجة كبيرة فى مصـر ،

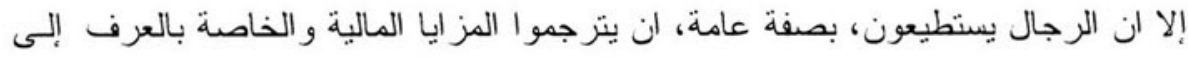

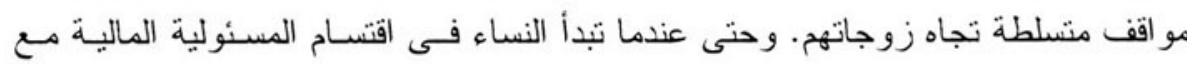
ازو اجهن فنادر ا ما يترجم ذلك إلى التساوى فى المشاركة فى مجالات اخرى. ويتعلق أحد بر امج التدخل المحتملة التى لم تفحص بعد فى مصـر بصـور علاقـات النوع فى وسـائل

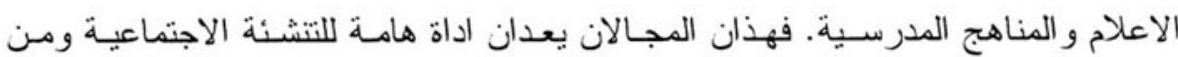
الممكن إستخدامهما لتشجيع تننى مو اقف جديدة تجاه الاناث وذلك بين البنين و البنات .

ولم تتعكس بعد التحسينات التى طر أت على انجاز المر اة التعليمى علىالمشـاركة

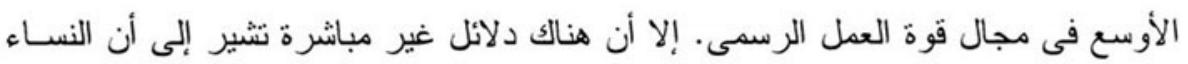

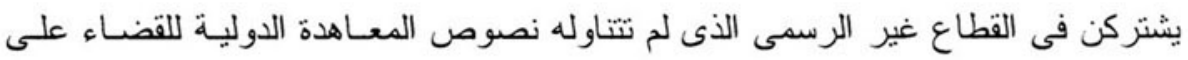

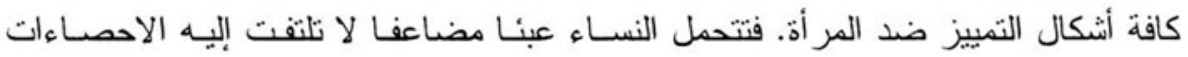


الرسمية. ومن اجل تحقيـق انصـاف اكثر فى مجـال سـوق العمل ومســاندة اكثر للأسـر

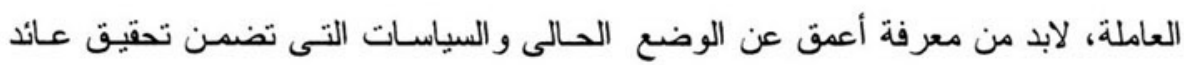

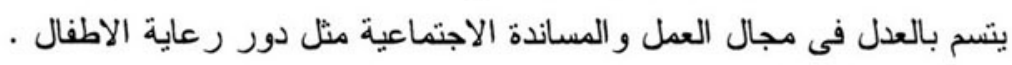

اما فيما يتعلق بتوصيل خدمات نتظيم الاسرة، والصحة الانجابية، فيجب تشـيع

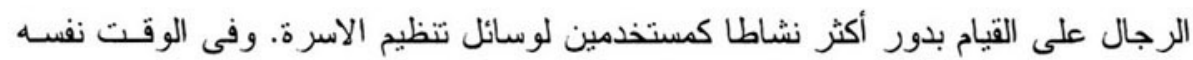

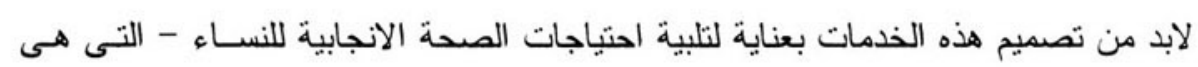

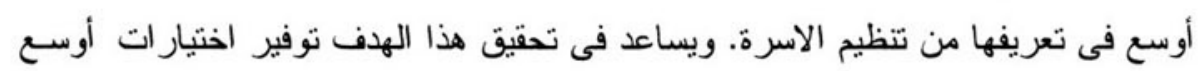

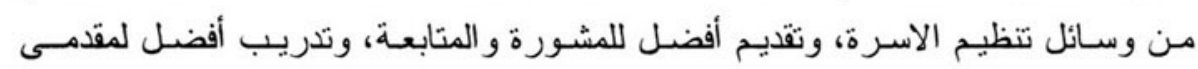

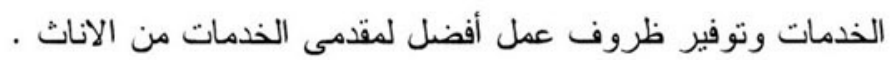

وسوف بِاهم التقليل مـن اوجـه عدم الانصـاف فـى الحيـاتين العامـة والخاصـة

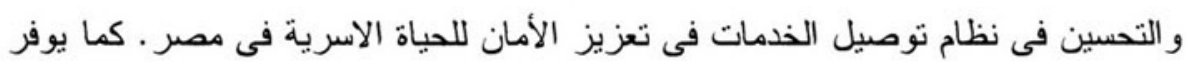

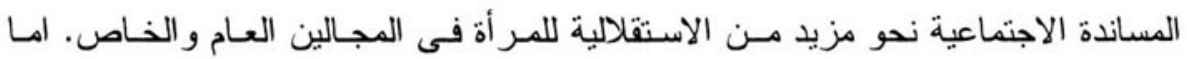

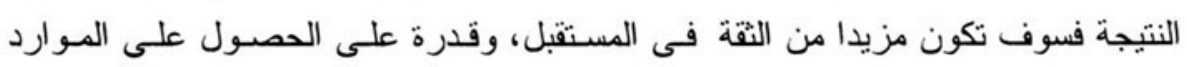
العامة والخاصة وقاعدة آمنة للوصول إلى اختيار ات طويلة المدى خاصة بالانجاب . لكئل 


\section{الهو امــــــــش}

(1) تعد الحجة المصرية مثال على الصر اع بين قيم حقوق الانسان المتتافسة - وهى في هذه الحالة - بين المساو اة في النوع وبين الحرية الدينية. ويحتل مبدأ المساو اة في النوع مكانه في ميثناق الامـم المتحدة.

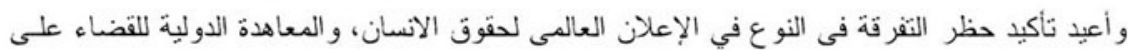

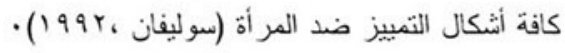

ويؤكد سوليفان أن "القانون الدولى بسمح بتطبيق القانون الدينى فى مجال القانون الوطنى كمـا يضمن

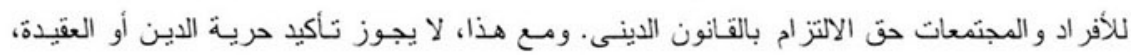

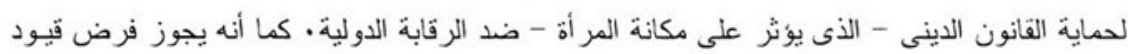

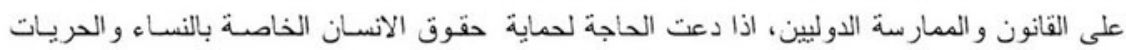

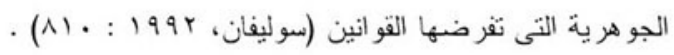

ويقدم سوليفان إطار ا يقوم على اساس معابير حقوق الانسان التى يمكن استخدامها لفض الصر اعـات

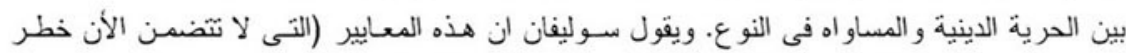

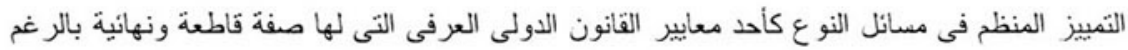

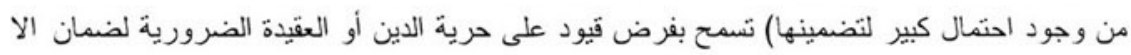

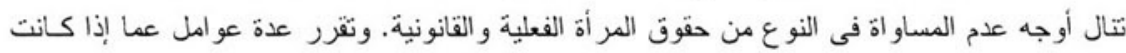

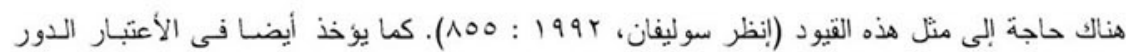

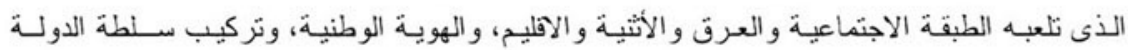
فىنشكيل الحقوق الفعلية للنساء .

تسنمد القيود الخاصة بالسن الأدنى للزواج من القانون المدنى العلمانى، وليس من الاسلام ولا يوجد فى إنى

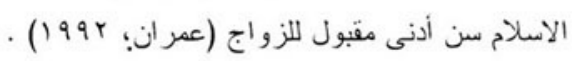

يظهر التزويج الضمنى للأسرة ذات الثثلاث اطفال التى يعبر عنها القانون المدنى العلمانى، فى الفتوى

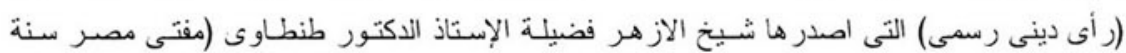

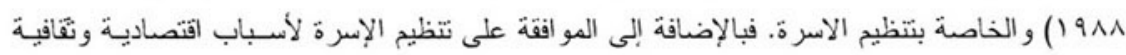

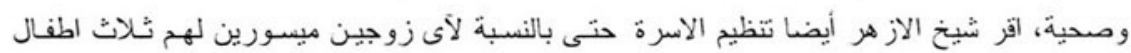

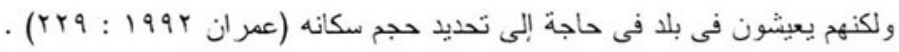

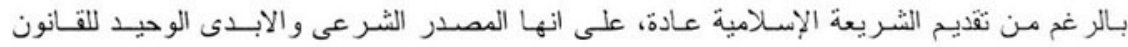

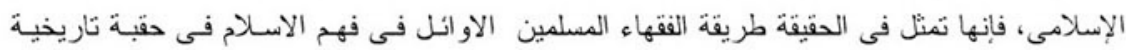
محددة (طوبيا و النعيم، بدون تاريخ). و على هذا الأساس بمكن للفقهاء المسلمين المعاصرين إعـادة بنساء

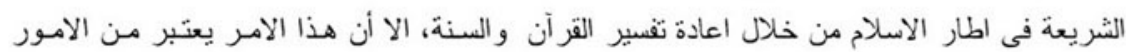

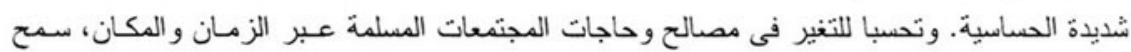
(فى الشريعة الإسـامية) بمجـالات للمرونـة والقدرة على التأقلم (عمران، ب9 (1 ). و لا يمكن تغيبير 
بعض عناصر الثريعة مثل العقائد الاسلامية الجوهرية و العبادات والاخلاق المستمدة من القر آن و السنة

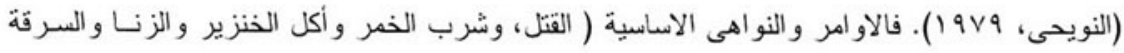

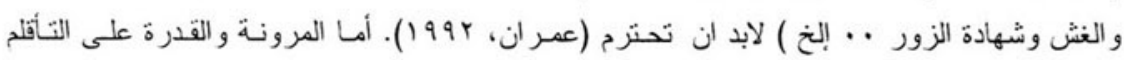

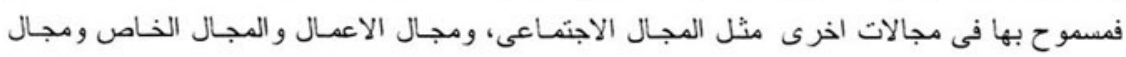

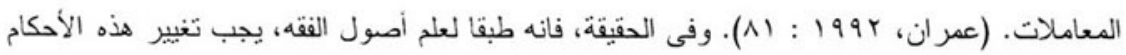

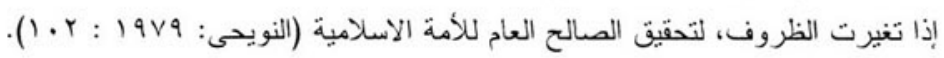

و هناك قضيتان تحفز ان جهود الاصلاح لتحسين مكانـة وحقوق النسـاء فى نطاق الشريعة الإسلامية

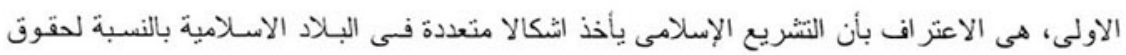

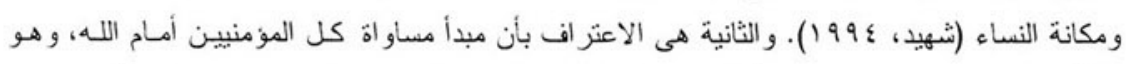

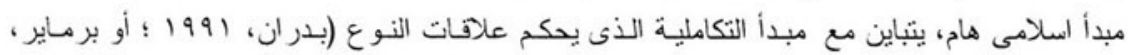

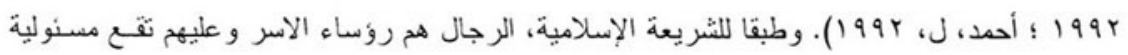

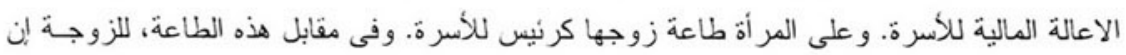

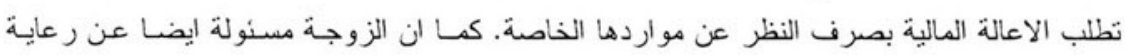

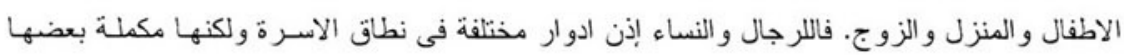

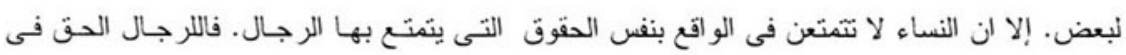

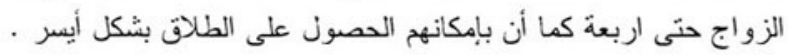

ومن الممكن تحقيق الاصلاح بعدة وسائل داخـل حـدود الصيـغ التّاريخيـة للتشـريع الاسـلامى بالدراسـة

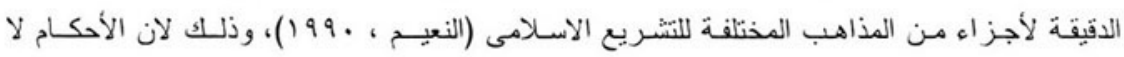

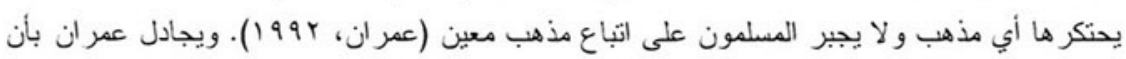

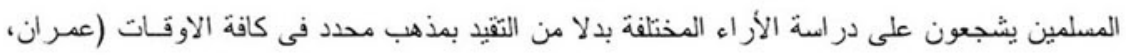

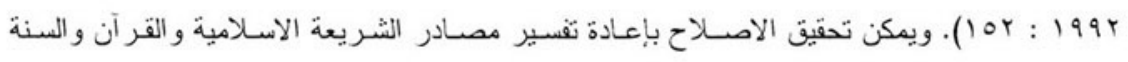

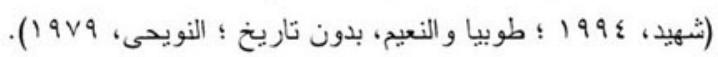

$$
\text { انظر روج (ع 9 ا ) للمناقثة حول ممارسات الزواج و الطلاق عند المسيحيين فى مصر . }
$$

17) يمكن ان يكون نظام مؤخر الصداق رادعا اقتصاديـا للطـلاق ( بـاون، ب99 ()). إلا ان تضمين مؤخر

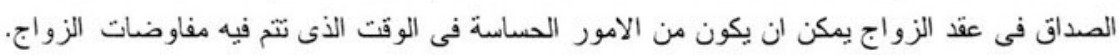

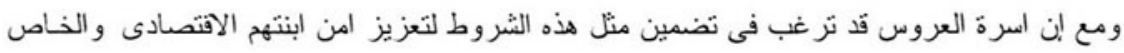

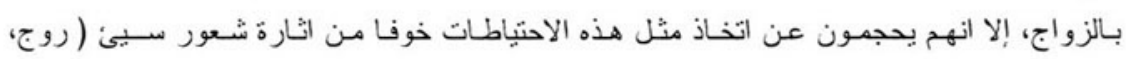
.$(19 \wedge \varepsilon$

يتعارض فانون المير اث المصرى مع مبدأ المساو اه فى النوع فى ميثّاق الامم المتحدة و القـر ار الصـادر

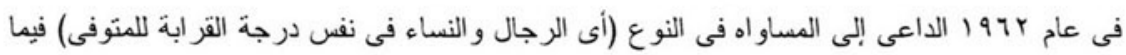

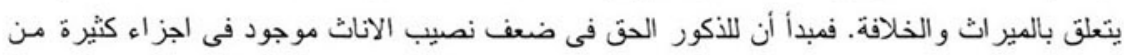


قانون المير اث. وينبغى، نظرياً، أن تقوم مصر بإدخال اصلاحات على قو انيين المير اث و الممارسـات

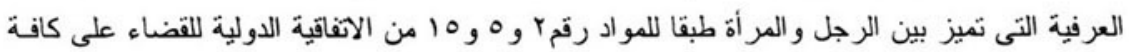

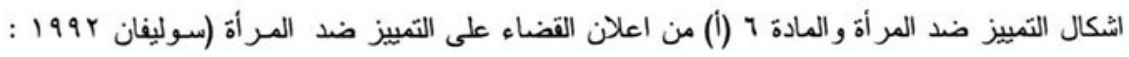

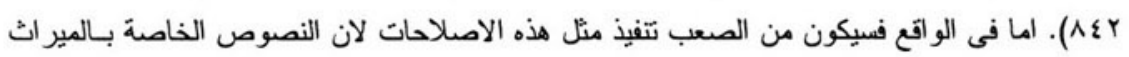

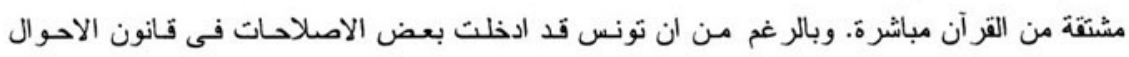

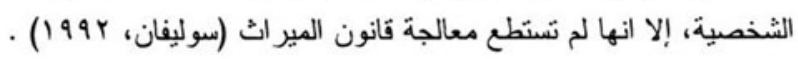

(^) للزوجة الحق فى الحصول على معاش زوجها المتوفى بصرف النظر عن معاشها الشخصى او حالتها

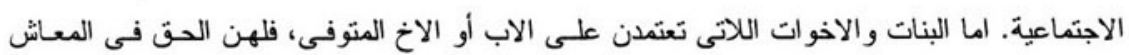

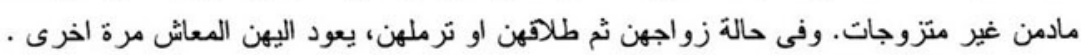

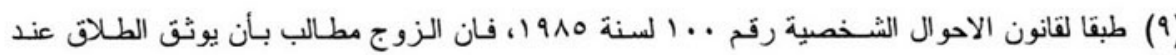

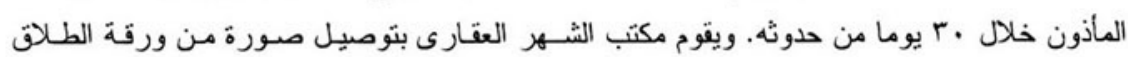
للزوجة المطلقة (مجموعة الاتصال، ع 99 (1).

( • (1) على عكس معظم نصوص قانون الاحوال الثخصية فى مصر المستمدة من المذهب الحنفى، فالاسباب

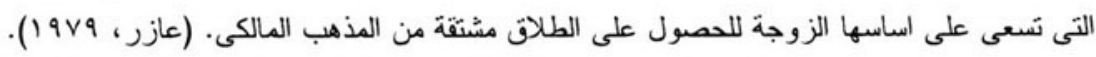

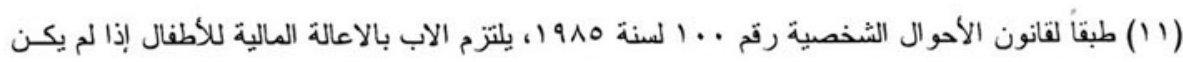

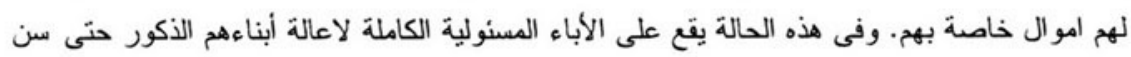

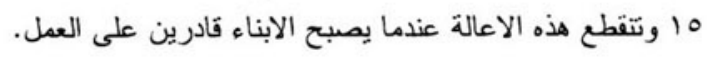

وتؤخذ فى الاعتبار عو امل مثل التعليم، والعجز العقلى أو البدنى وعذم توفر فرص عمـل عند تحديد "

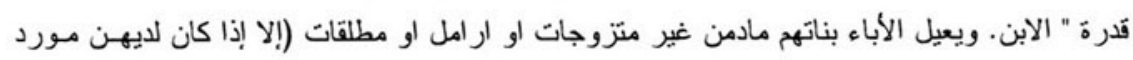

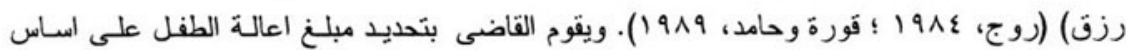

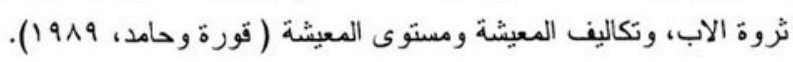

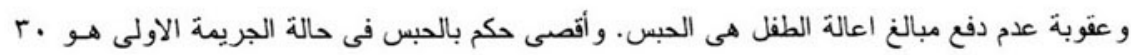

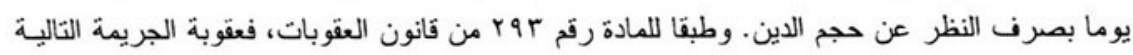

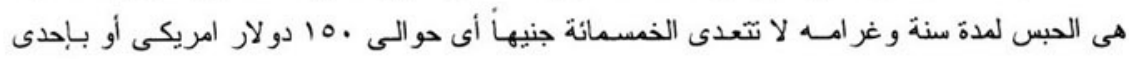

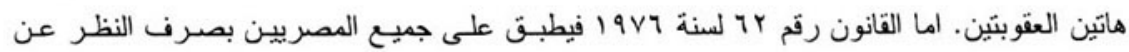

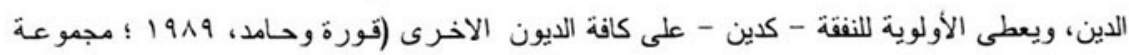

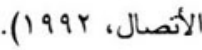

ومسنولية الأباء ( او اقرب رجل مثل والد الأب أو الأخ ) فى دفع النفقة لا تعتمـد على وضـع الأبـاء

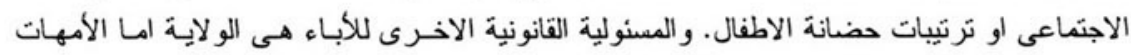

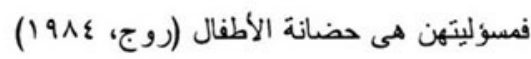


(r ( ) للزوجة المطلقة الحق فى مبلـنع الاعالـة لمدة عـام بالأضافة إلى تعويض بسـاوى مبلـغ الاعالـة لمدة

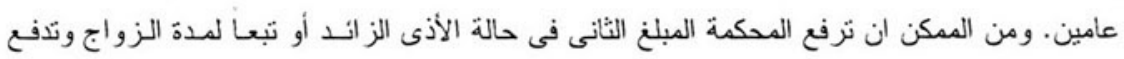

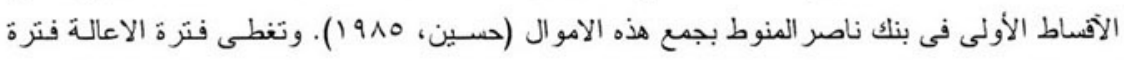

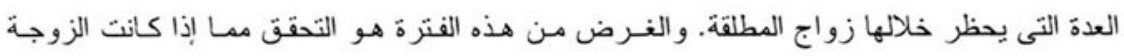
حاملا من زوجها السابق. ونتمتع المر اة فى فترة العدة بالحقوق الاخرى التى نتمتع بها الزوجة ولثة القانونية

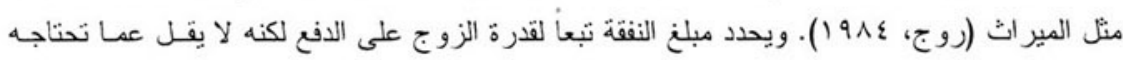

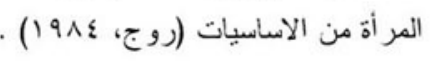

وبهدف الحفاظ على حق الزوجة فى النفقة فى حالة الطلاق، من المهـم ان يتضمن عقد الزواج شرط

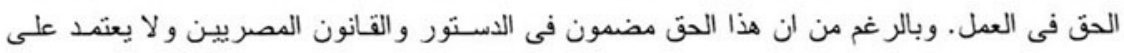

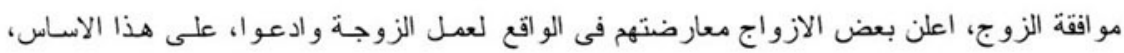

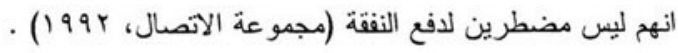

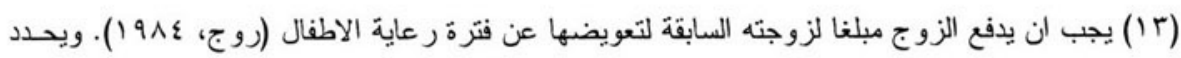

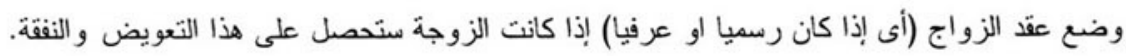
وبصفة عامة، لايحق للزوجة المطلقة ان تحصل على النفقة وتعويض رضات رضاعة الطفل معا. و على سبيل

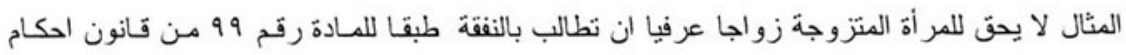

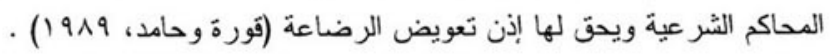
(ع 1) تثمتع النساء المسلمات و المسيحيات بهذا الحق (مجموعة الاتصال، ب99 ( ) .

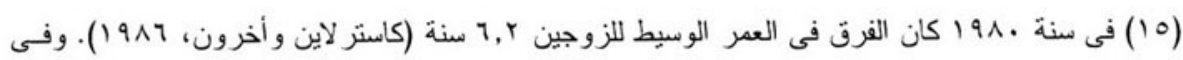

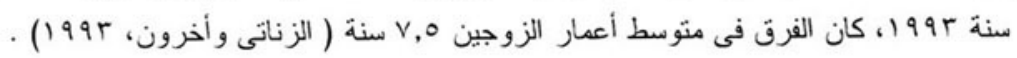
(1 (1) بالر غم من أنه مسموح للرجـال من المسـلمين بـالزواج حنى أربعة، فالاسـلام يـأمر هم بالمسـاو اة فى معاملة الزوجات. و على عكس البلاد الاسلامية الأخرى، فابن تطبيق مصر للقانون الاسلامى في مسألة

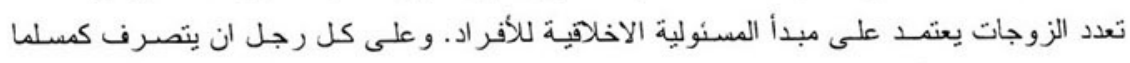

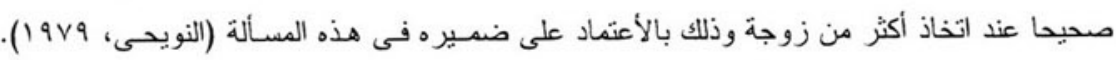

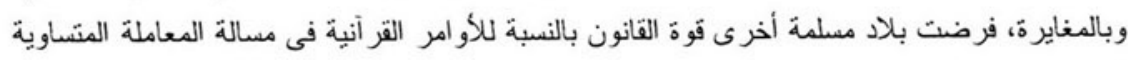

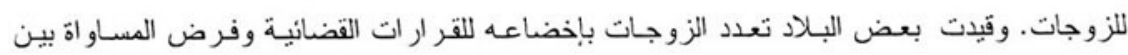

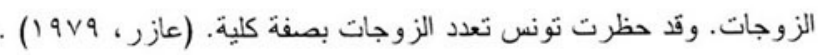

ونكتب روج بان الهدف من ممارسة تعدد الزوجات بين الاسر الحضرية مـن الطبقات الدنيـا كثبر ا مـاـ

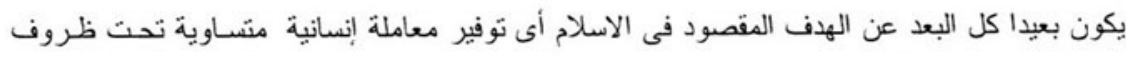

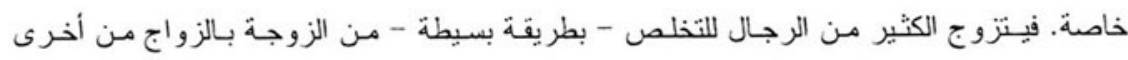

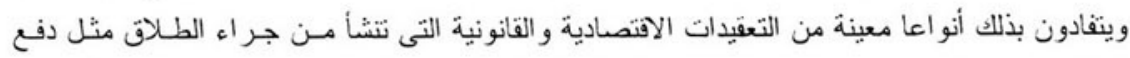

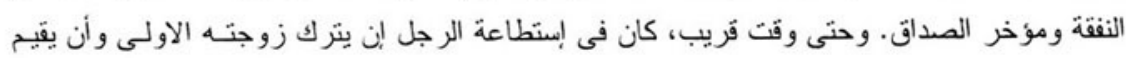


مع زوجة ثانية أما سرأ أو علانية ويستطيع بهذه الوسيلة تفادى دفع النفة والمهر ـ أما الان فلابد للرجل

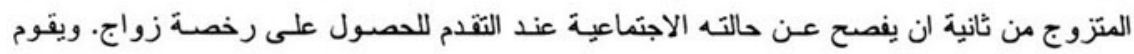

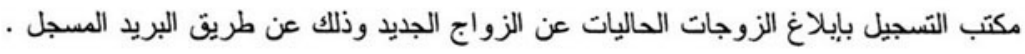

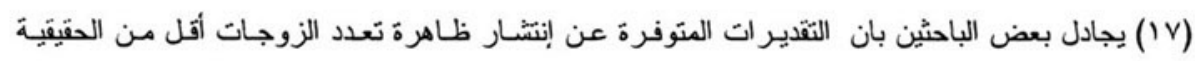

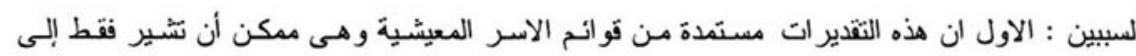

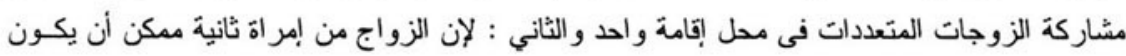

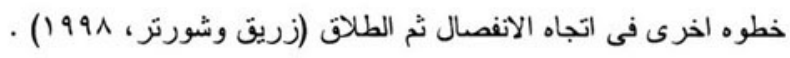

(1) من المثير ملاحظة إن تونس تروج لنموذج مماثل من علادات النوع داخل الاسرة بعتمد على العلافات

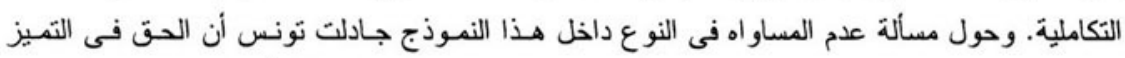

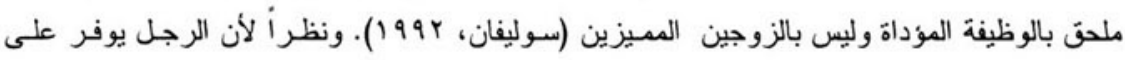

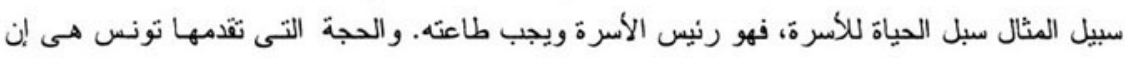

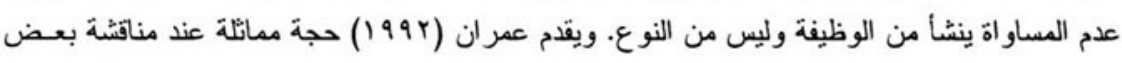

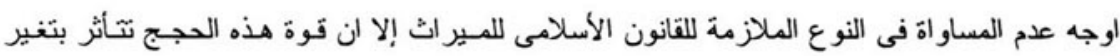
الوظائف الفعلية لكل من الرجال والنساء .

(9 (1) أوضحت اصلاحات سنة 9V9 ا معنى "إعالة الزوج للزوجة" التى نص عليها فى المادة رقم 1 للقانون

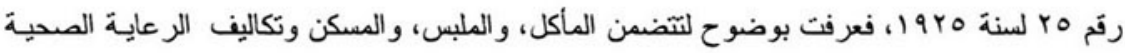

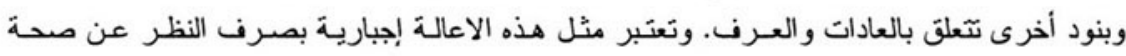

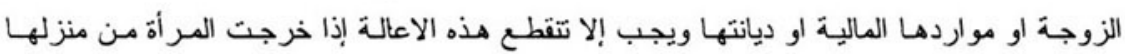

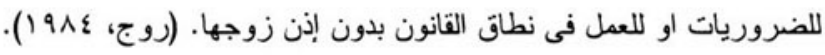

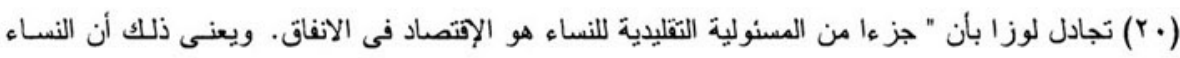

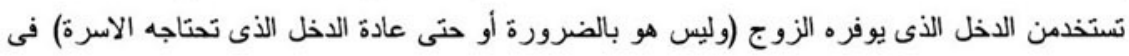

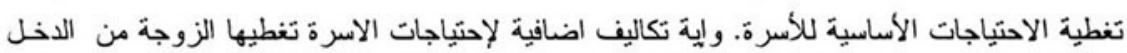

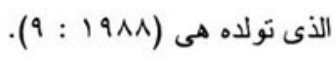

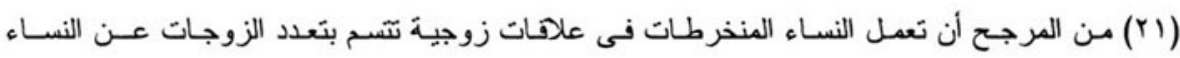

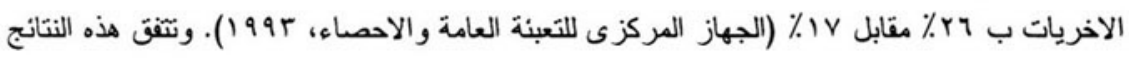

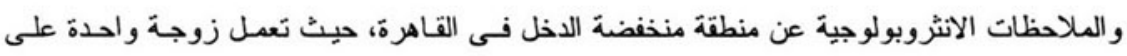

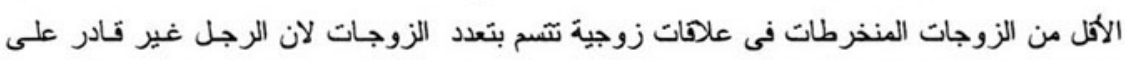

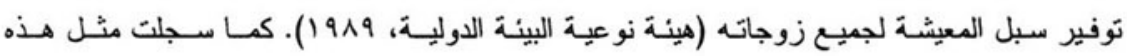

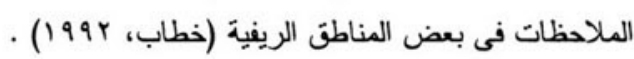

(YY) من الجائز ألا يعول الازواج اسر هم بسبب البطالة أو عدم الثـور بالمسئولية (هيئة نوعية البيئة

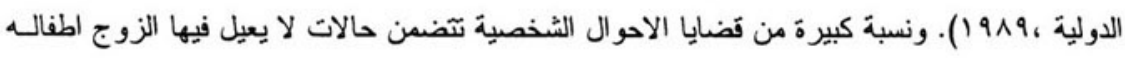




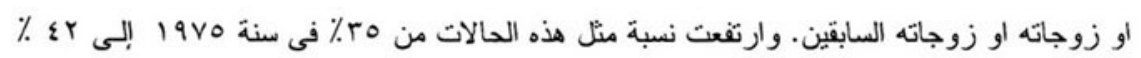

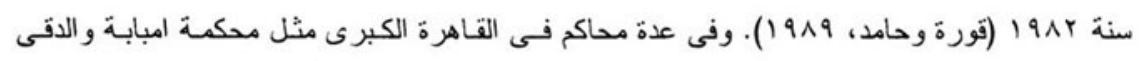

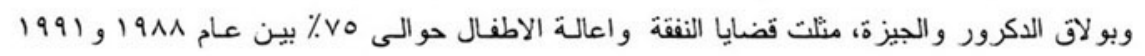

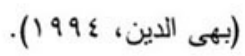

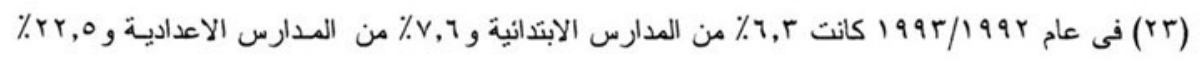

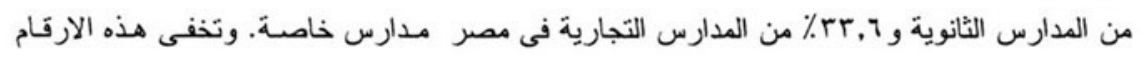

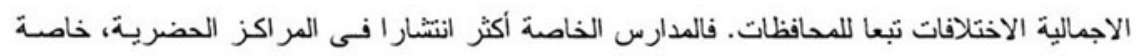

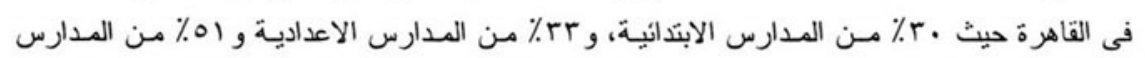

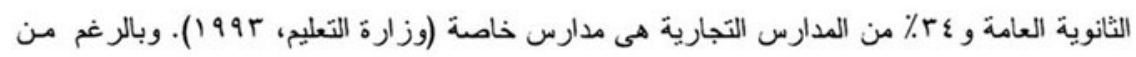

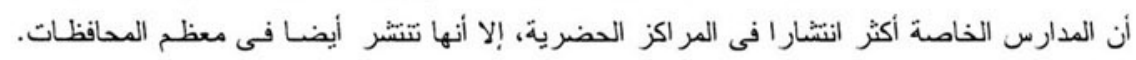

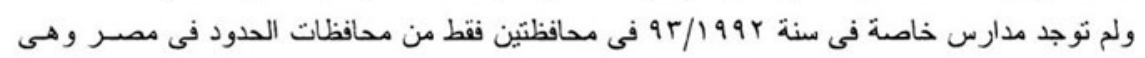

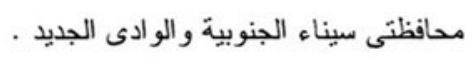

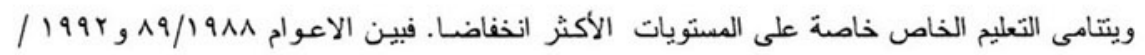

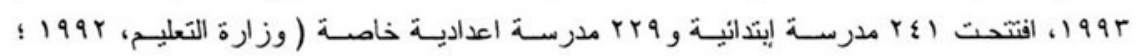
.(1995

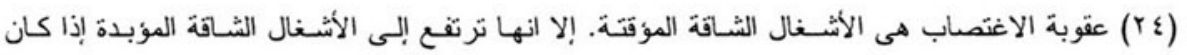

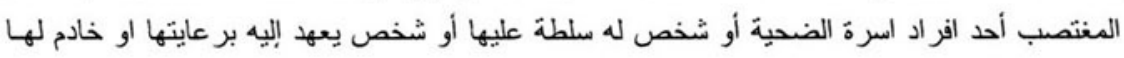
. (1999 (محسن، (19) (ro) مثل حالة تايلاند التى اختبرث تجربة انذفاض سريع للغاية في الخصوبة . (TY) يعضد المسح المصرى لانفاق الاطفال (1990) هذه النتائج. فالنساء اللاتى يلعبن دورا أكبر فى اتخـاذ

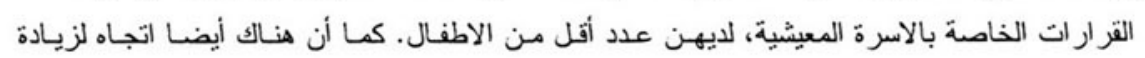
الانفاق على كل طفل (وقد وجدت هذه العلاقة بعد التحكم فى تأثير دخل الاسرة ومنطقة السكن وتركيب

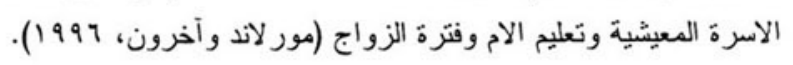

I IrV لمصر ناريخ طويل فى تطبيق نظام التعليم الابتدانى الاجبـارى فقد جعلت وزارة التعليم سنة (rV)

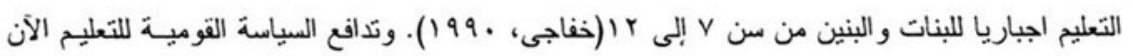

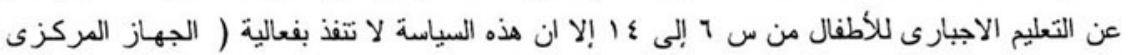
للتعبينة العامة و الاحصاء و اليونيسف،

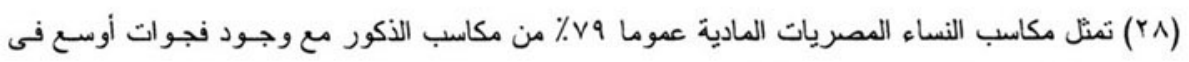
مجال المهن اليدوية (زيتون، 199 (19) . 


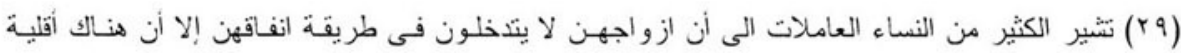

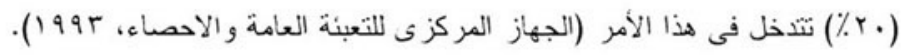

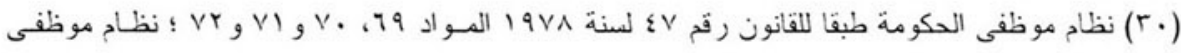

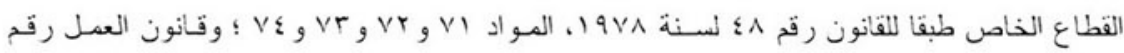
V. IrV

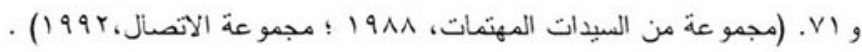

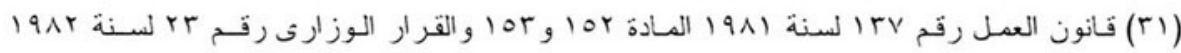

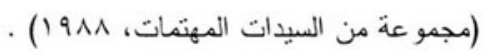

(rr) قد نتضمن الخدمات الأخر ث مبالع للمو اصلات و الوجبات بقدمها صاحب العمل .

(tr)

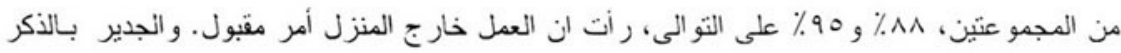
أن هذا هو أيضا رأى الكتاب الدينيين فى أن الثعليم و الطب هما مـن أكثر الوظـائف ملاعمـة للنسـاء. (

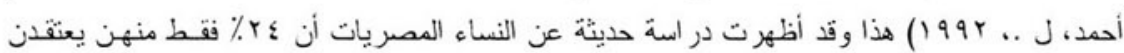
ان بعض الوظانف اكثر ملاعمة للنساء من غير هـ مثل مهن التذريس و التمر بـض و الاعمـال المكثبية

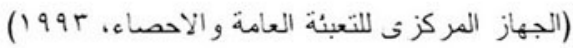

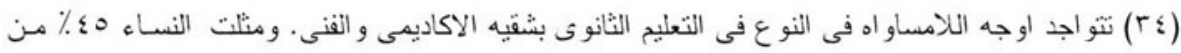

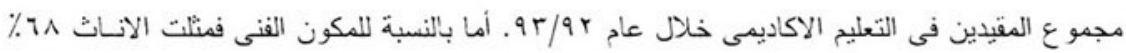

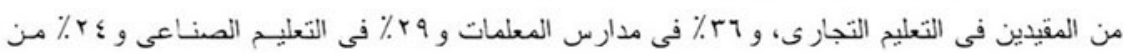

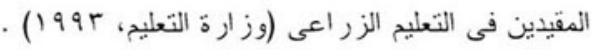

وتعكس اوجه اللامساو اة فى القيد في التعليم الفنى الاختلافات الثقليدية للنوع فيما يتعلـق بـالمهن بـلر غم

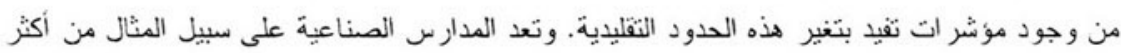

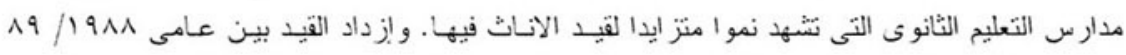

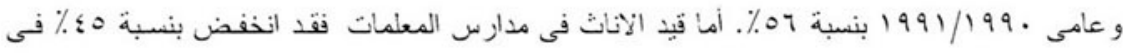

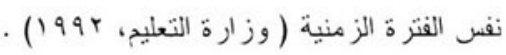

(ro) صر حت طالبات الجامعة - ولبس فقط الأباء من الطبقات ذات الدخل المنخفض عن رأيهن فى أن

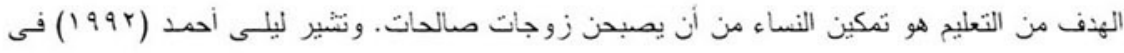

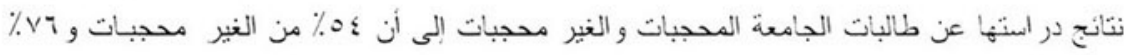

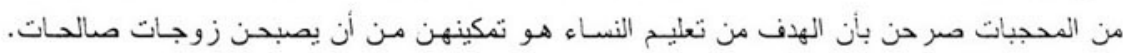
وصرحت نسبة من الطالبات نمثل أقل من 1 ٪ أن الهدف من التعليم هو تأهيل النساء للعمل . 
(Tr) أ شار موظف فى إحدى قرى وجه ثبلى الى" أن الكثير من الفلاحين لا بسمحون لبناتهم بـرك البيبت

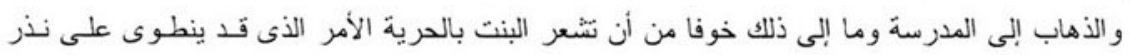

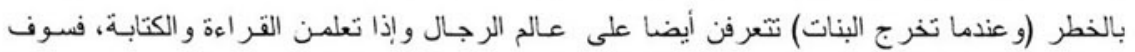

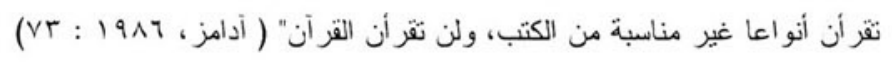

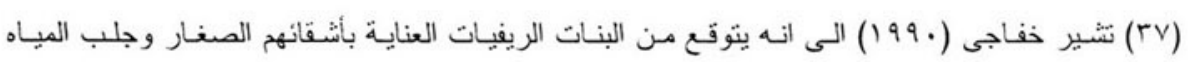

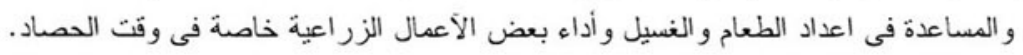

ومن الشائع في صعيد مصر أنـه إذا ذهبت البنـات إلى المدرسـة، ألا ينتظمن فيها. وتصر ح خفاجى

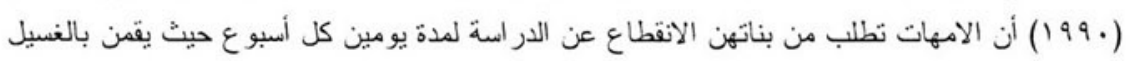

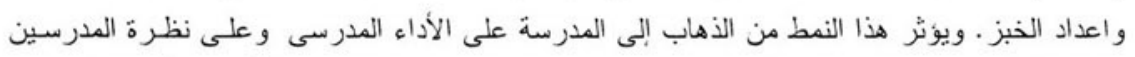

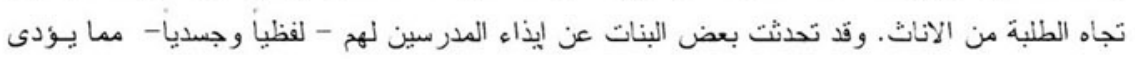

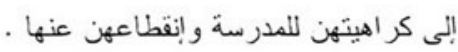

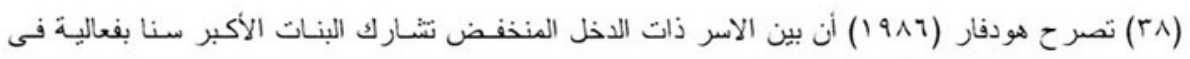

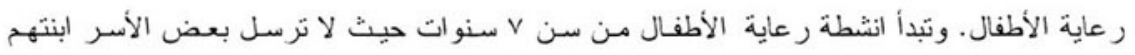

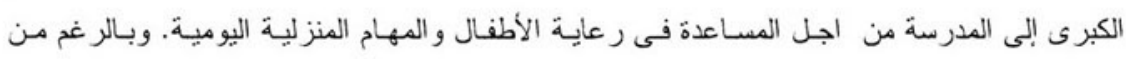
انكسار هذه الممارسة، " إلا أن اكبر البنات سنا ما زلن مسنو لات عن جزء الكئ كبير من الأعمال المنزليـة،

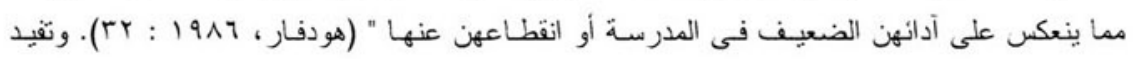

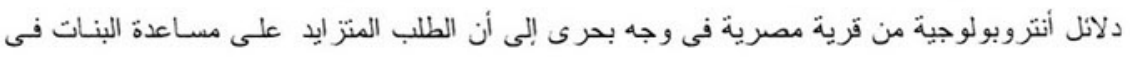

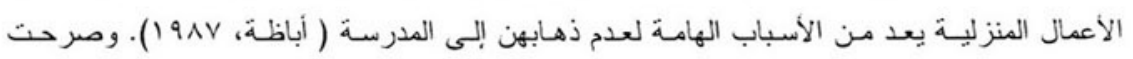
الامهات من هذه القرية أن الظروف المادية لم تمكنهن من تعليم كل اطفالهن، لذا فقد ركزن على لألى تعليح

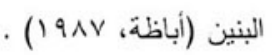

(q) نتضمن اتفاقيات الامم المتحدة التى صدقت عليها مصر اتفاقية القضاء على كافة اشكال الثمييز ضـا

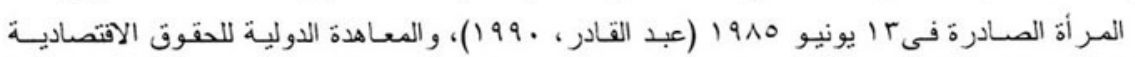

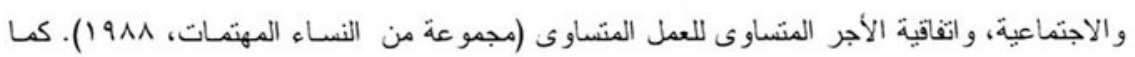

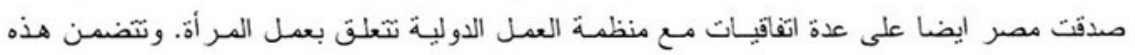

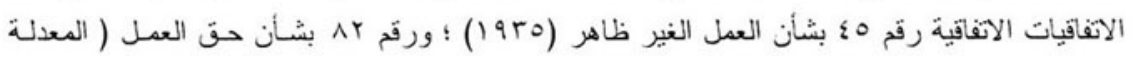

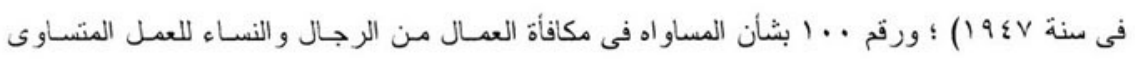

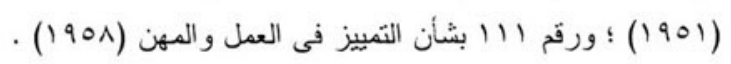

( • ؛) اعربت مصر عن تحفظاتها بشأن المـواد الاربعة مـن الاتفاقيـة : المـادة 9، الفقرة الثانيـة التى تمنح

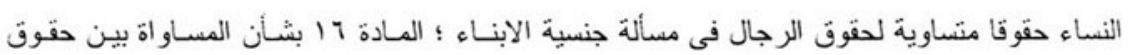

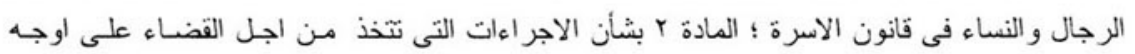


التمييز والمادة 9r، الفقرة الثانية بشأن اللجوء الى التحكيم لحل الخلافـات بين الدول اللاطر اف فى الاتفاقية .

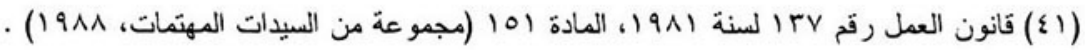

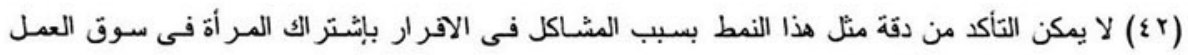
(انكرو أنكر ، 919 1) ). وقد وجد نمط بديل للسن فى در اسة عن أحدى التجمعات السكانية فى القـاهرة

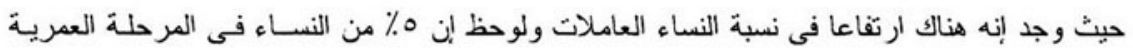

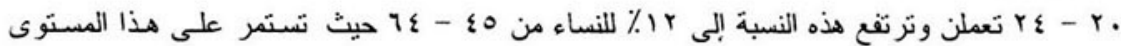
بعد ذلك (شورتر و الطويلة، . 199 : 19 (1). و هناك حاجة إلى المزيد من البحث لدر اسة هـذا النمط لان نمط السن بالنسبة لعمل المر أة يؤثر على طبيعة نظم المسـاندة التى تحتاجها النسـاء العـاملات لرفاهيـة الاسرة .

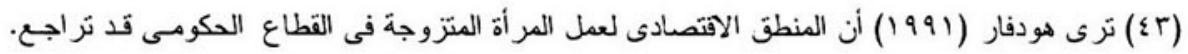
فمز ايا هذا التوظيف أى الاجور الضعيفة، قد تذنت أمـام التكاليف الباهظة (التكـاليف المباشـرة للملبس

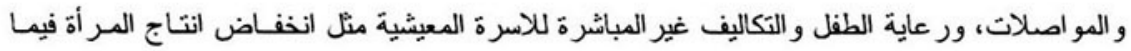
ينعلق بالأسرة المعيشية والانخفاض فى قدرثها على شر اء مستلزمات المنزل وما إلى ذلك). (ع ع) من المرجح أن إرنداء الزى المحافظ هو احد الاستر اتيجيات التـى يمكن النسـاء اتباعها للتقليل من

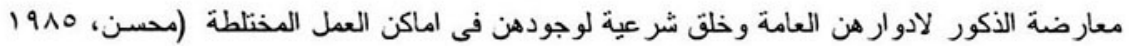

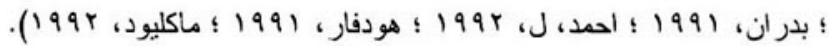

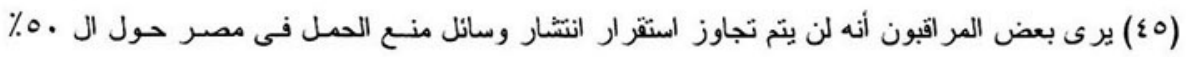
بدون السماح بالاجر اء الجراحى كوسيلة من وسائل تنظيم الاسرة الاختيازية.

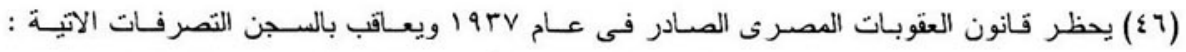

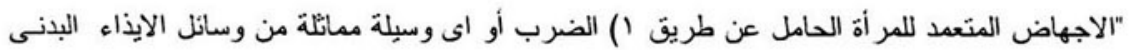

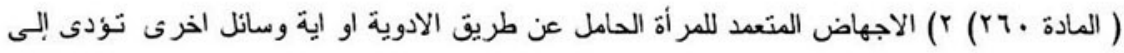

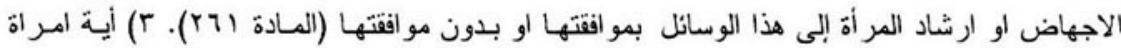

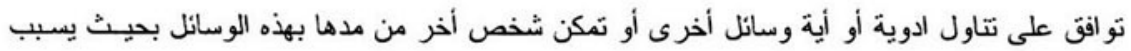

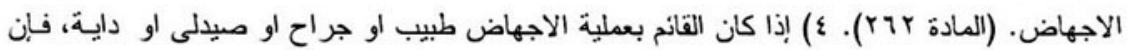

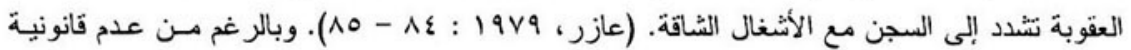

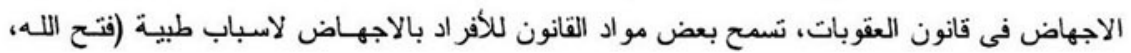
r99 1، ذو الفقار ، 199 1 ب)، لذلك يعتبر الاجهاض لاسباب طبية قانونيا . 


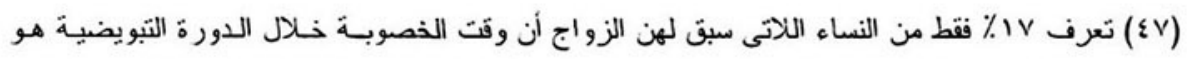

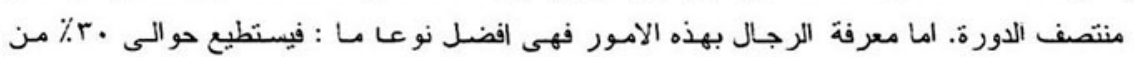

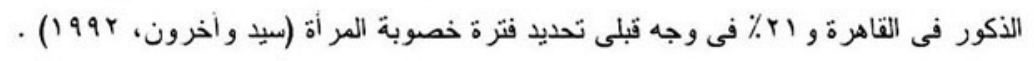




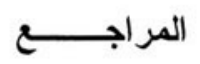

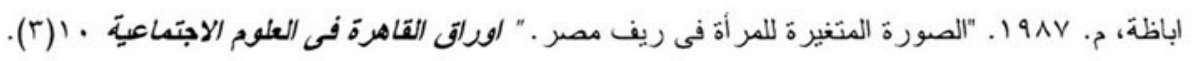

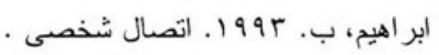

ابر اهيم، س. . 990 ـ ـ "الدوله و النساء و المجنمع المدنى: ثقويم لسياسة مصر السـكانية". ندوه مجلس السكان

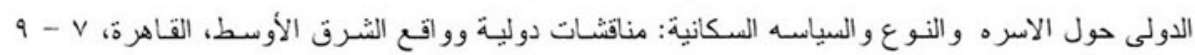
فبر اير ع9 199

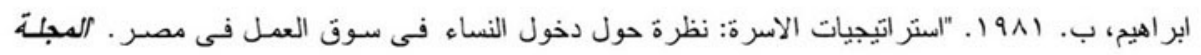

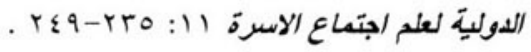

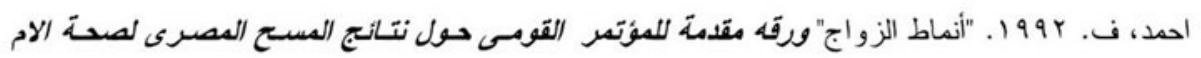

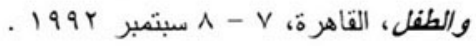
احمد، ل. r ra9 ا ـ النساء والنوع فى الاسلام. نيو هيفن. مطبعة جامعة ييل . آدامز ، ر. ـ 1191 ـ التنصيّة والتغيير الاجتماعى فى الريف المصرى. سير اكيوز : مطبعة جامعة سبر اكيوز .

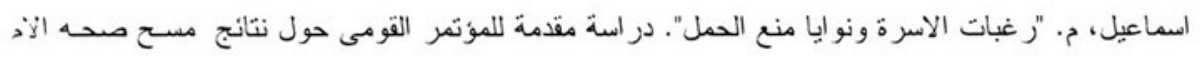

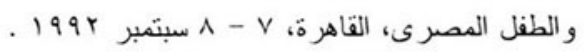

اسماعبل أ. أو9 1. انماط و اتجاهات السكان النشيطين اقتصاديا فى مصر فى التحليل الديموجرافى لبياتسات

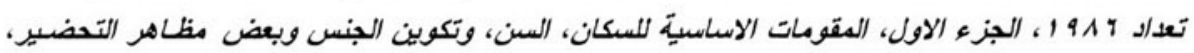

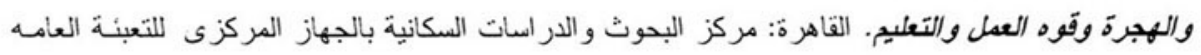
والاحصاء.

$$
\text { الامم المتحدة. 1911 ا ـ سياسات العالم السكانية. . نيويورك: الامم المتحدة }
$$

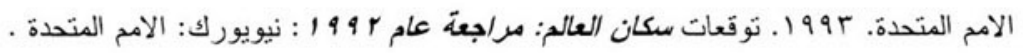

انكر ، د. وم. انكر . 919 1 . "قياس قوة عمل الانـات فى مصر ." عرض العدل الدولس 1r 1 (ع): . or.

اوبرماير ، ك. بو9 1 . "الاسلام و النساء و السباسة: ديمو اجر افيا البلاد العربية". مجلة السكان والتنمية النقدية . 7 -rr: (1)1^ 
ايرلى. أ. 1910 ا. "فاطمة : قصة حياة امر أة مصرية من بو لاق. " فى النساء والاسرة فـى الشرق الاوسط. تحرير أ. فرنيا. أوسنز : مطبعة جامعة نكساس.

بابانك، هـ. وب. ابر اهيب. بهو 1. "المشاركة الاقتصادية للنساء المصريات: الدلالات على خلق قوه للعمل

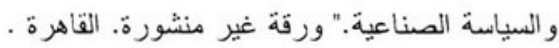

باون، د. rو9 1. "القانون الاسلامى ووضع المر أث". مسـوده معدة للبنـك الدولى فى اوروبـا، اقليم الثـرق الاوسط وشمال افريقيا .

بدران، م. او99 ا. "صر اع جداول الاعمال : انصار حقوق المر أة و الاسلام و الدولة فى القـرن الثناسع عشر

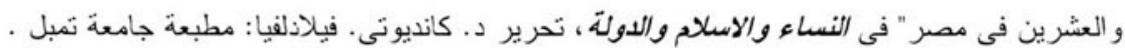

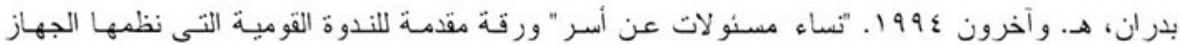

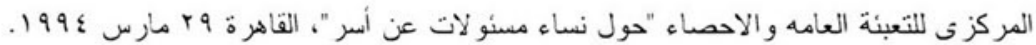

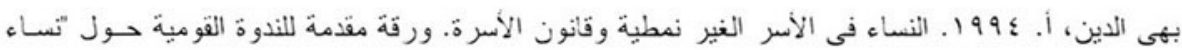

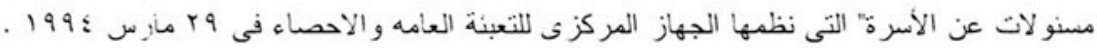

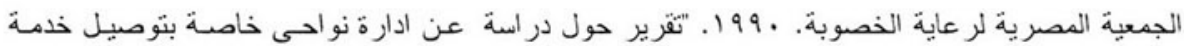

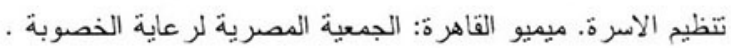

الجهاز المركزى للتعبئة العامة والاحصاء و اليونيسيف. 911 ا ـ حالة الأطفال المصريين. القاهرة: الجهاز المركزى للتعبئة العامه و الاحصاء و اليونيسيف .

الجهاز المركزى للتعبئة العامه و الاحصاء و اليونيسيف. بو9 1 ـ وضـع النساء فـى مصر . القاهرة: الجهاز

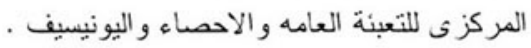

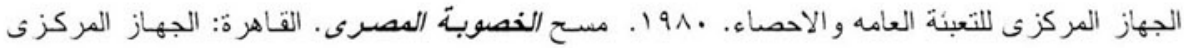
للتعبئة العامة و الاحصاء .

الجهاز المركز ثى للتعبئة العامه و الاحصاء. بو9 19 ـ "تقويم نو عية خدمات نتظيخ الاسرة في مصر ." ورقة

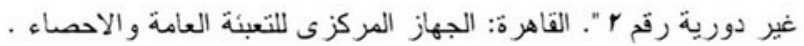

الجهاز المركزى للتعبئة العامه و الاحصـاء. r991 ـ " دراستح حسل دور النساء المصريات." جداول غبر

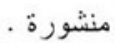


جو هل، ن. 99 1. "انماط عمل الاطفال فى مصر : دلانل مـن در اسـة حـول التعليِم والاسـتبقاء العددى فى

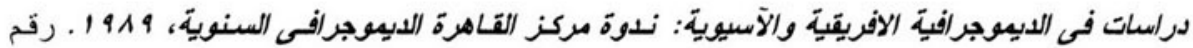
9 1، القاهرة: مركز القاهرة الديموجر افى .

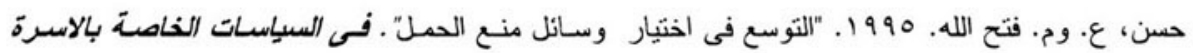
والنوع والسكان فى الشسق الاوسط. تحرير ك.م. اوبر ماير . القاهرة: مطبعة الجامعة الامريكية .

حسين، أ. ه19 1 ـ "التغير ات الاخيرة فى القانون المصرى للاحو ال الشخصية." النساء والاسرة فسى الشسرق

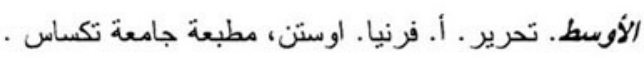

خطاب، هـ. rو 1 ا. المعاناة الصامته: جوانب من الظروف الاجتماعية المحيطة بصحة المرأة الاجبابية فسى

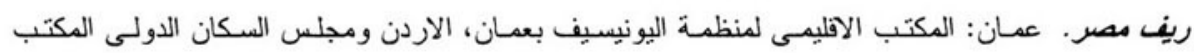
الافليمى. (عمل مشنرك) .

خفاجى، ف. ـ99 1. "الفرص المتساوية للبنات و النساء فى مصر ." ورقـة مقدمة للمؤتمر السنوى الخـامس

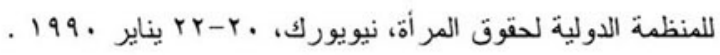
الخولى، هـ. "علام البنت كنز" . 997 ا. ـورقة غبر منشورة .

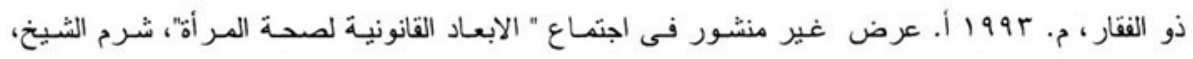

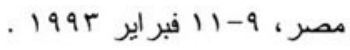
ذو الفقار ، ج. r99 1 اب. اتصال شخصى · ذو الفقار ، م. r99 ا ج. "وضع المصريات فى نطاق اتفاقية النساء لعام 9V9 ا". ورثة غير منشورة.

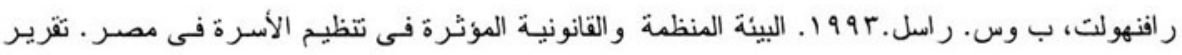
خاص اعد للمجلس القومى للسكان فى نطاق مشروع "الاختبار ات ب". و واشنطون.

رجب، أ. ر. ـ 9 190 . "عملية اتخاذ قرار الاجهاض غير الشرعى: دراسة حالة من الريف المصرى." دراسة للاكتور اة من جامعة اكستير بالمملكة المتحدة (غير منشورة). رو ج، أ. عـ9 ا ـ الاسرة فى مصر المعاصرة. سير اكيوز : مطبعة جامعة سير اكيوز . روج، أ. 910 ا "النساء و العمل: الاستر انتيجيات والاختيار ات فى حي للطبقات الدنيا فى القاهرة. "فى النسـاء

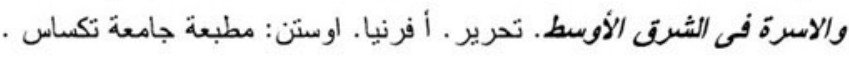


روج، أ. اوه 1 ا. اعادة رسم العلاهات الشخصية فى ممر فى" الاصوليه والمجتصع" . تحرير م. مارتى ود.

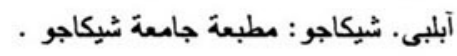

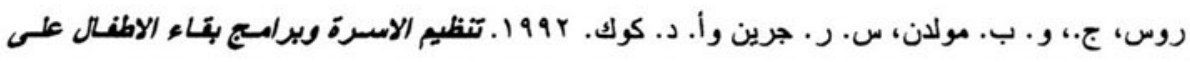

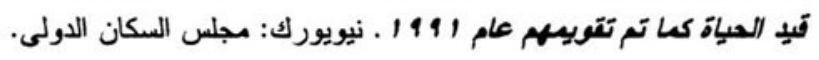

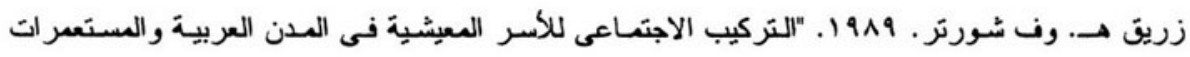
السكانية: القاهرة وبيروت وعمان." اصراق اقليويَّة . القاهرة: مجلس السكان الدولى، المكتب الاقليمى لمنطتحة غرب آسيا وشمال افريقيا .

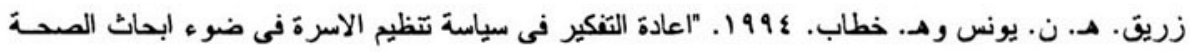

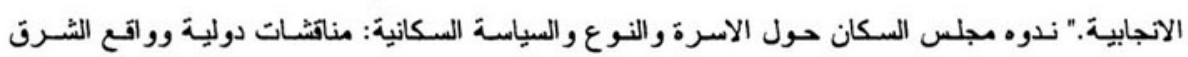

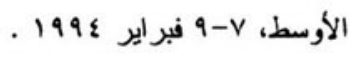

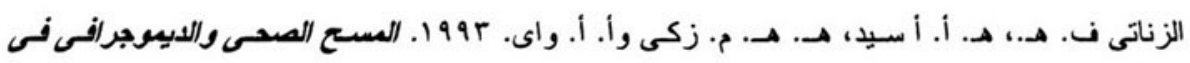

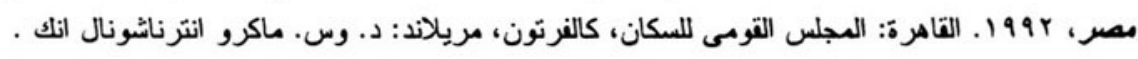

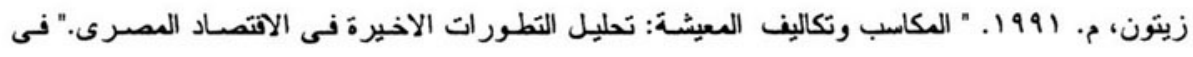
التوطيف والتكيف الهيكلم: مصر فى التسعينيات. تحرير هـ. حندوسة وج. بوتر القاهرة: مطبعة الجامعة الامريكية .

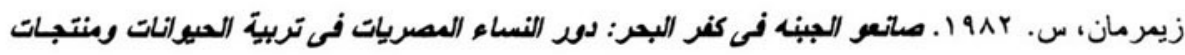

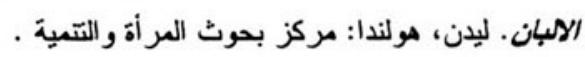

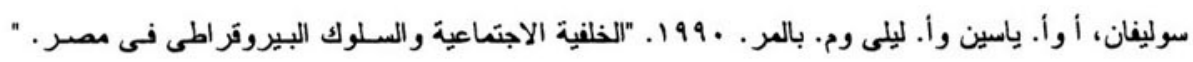

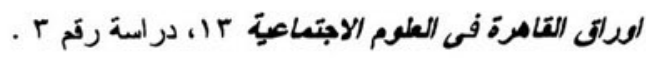

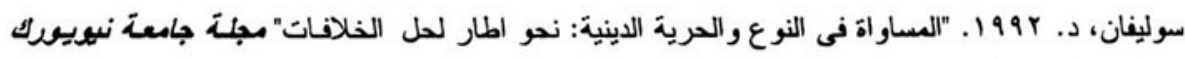

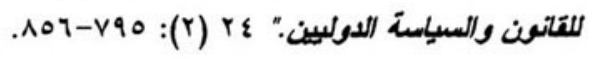

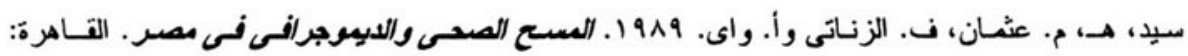

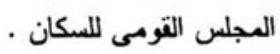

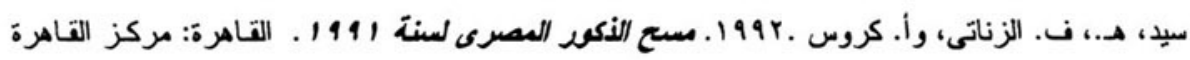

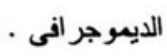


سيد، هـ. 9 ه 9 . . "السياسة السكانية فى مصر ." فى السياسات السكانية فى العالم الثالث: القضايا والتطبيق.

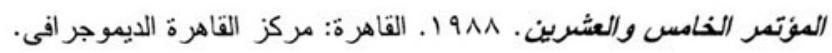

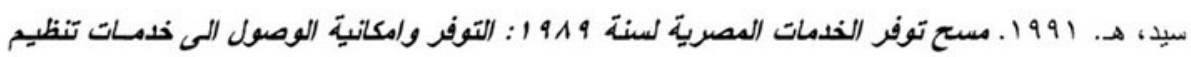

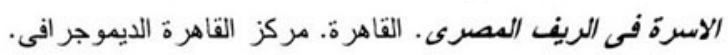

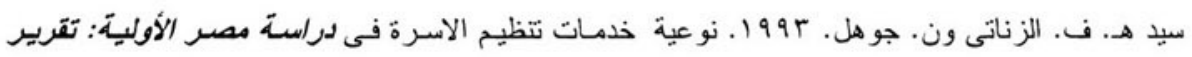

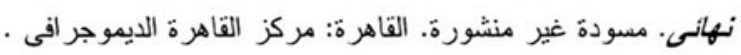

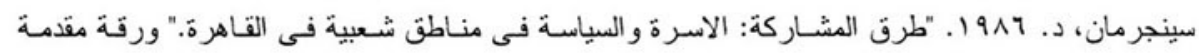

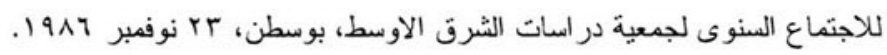

شهيد، ف. ؟99 1. "مسيطر عليهن ام مستقلات: الهويـة وتجربـة شبكات النسـاء اللآتى يعشن فى نطـاق

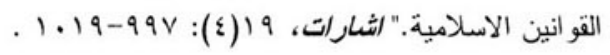

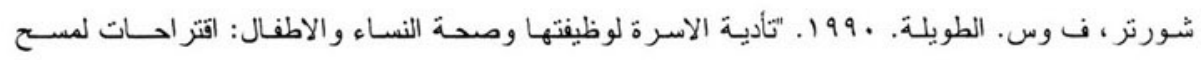

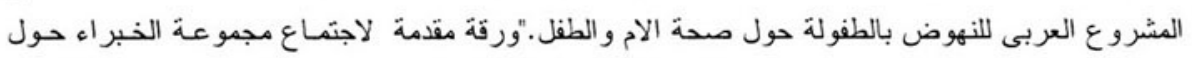

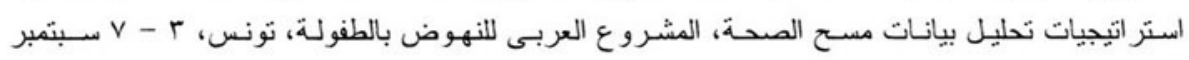

.199.

شورتر ، ف. 919 ا. "خطوة القاهرة إلى الامام: الناس والاسر المعيشية واماكن الحباة." اوراق القـاهرة فس

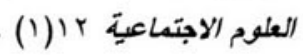

طوبيا، ن. و ·ع. النعيم. بدون تاريخ. " الابعاد القانونية لصحة النساء فى البـلاد العربيـة والاسـلامية". ورقـة

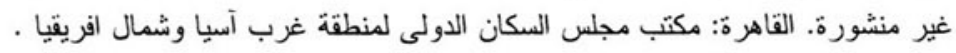

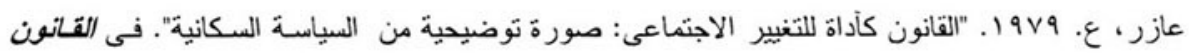

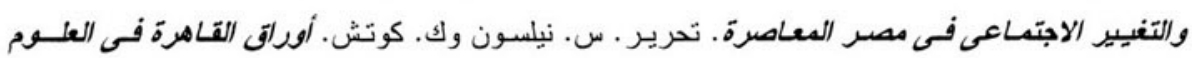

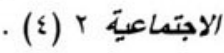

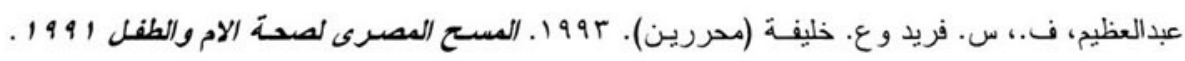
القاهرة: الجهاز المركزى للتعبئة العامه والاحصاء و المشروع العربى للنهوض بالطفولة.

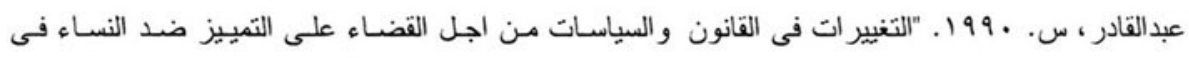

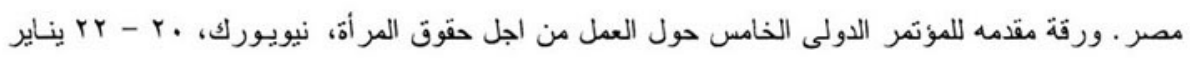


عبدالقادر ، س. ـ99 1. . "النساء المصريات و الصحة". مسودة مقدمة لليونيسيف، القاهرة.

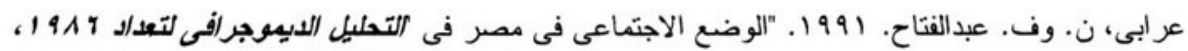

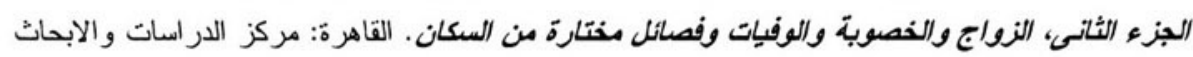

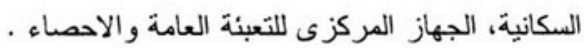

عشيبة، أ. بو 19 ا. "وفِيات الرضع والاطفال". ورفة مقدمة إلى المؤتمر القومى حول نتانج مسـح صحسة الام

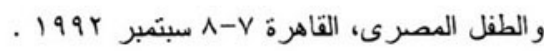

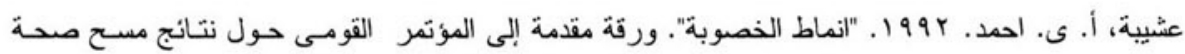

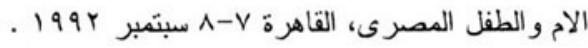
عمران، أ. ب99 ا ـ تنظيم الأسرة فحى المبراث الاسلاعى. نيويورك: دوتلدج . فتح الله، م. ب99 ا9. اتصال شخصى . قورة. أ. و ج. حامد. 919 1 . تشريعات الطفل فى مصر. القاهرة: اليونيسيف . كاستر لاين، ج. ب. ول. ويليامزو ب. ماكدونـالد. 19 1 ا ـ "فرق السن بين الازواج: اختلافات بين الدول

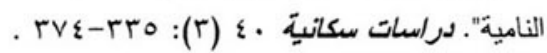

كنودل، ج، ن. هافانون ووسيتيتر اي. ـ991 . "حجم الاسرة وتعليم الاطفال فى نطاق الانخفاض السـريع فى

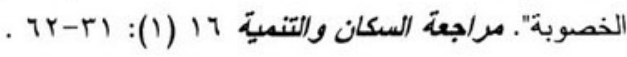

كونشرين، س.، ك، ميهر ا وأ. عشيبة 19 1 ا. "اشتر اك الاطفال المصريين فى التعليم". فى مصر: استجابات

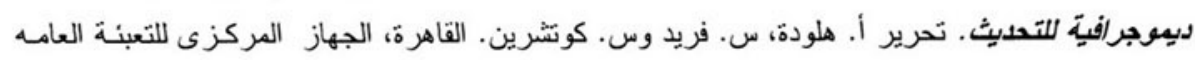
والاحصاء .

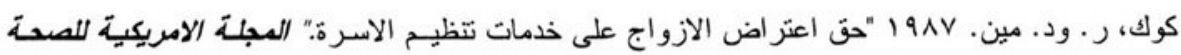

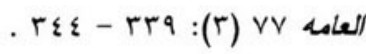

لانجستين، د. وأ. هيلِ. 199 ا. "بقاء الاطفال على قيد الحياة، الثقرير النصف سـنوى الثالث." ثثرير كامل حول الدورة الاولى لجمع البيانات. غير منشور . لجئ. لوزا، س. 1911 ا. العمل والاسرة فى مصر . ورقة غير منشورة. القاهرة. 


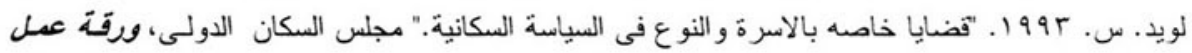

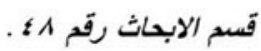

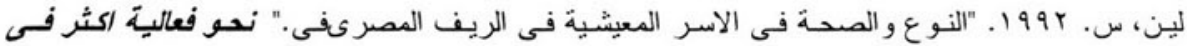
استراتيجيات صحة النساء ويقـاء الطفل على قيد العياة. تحرير ـ أ. سر اج الدين ور ـ دافيز ـ بـالتيمور : مدرسة جونز هوبكنز للصحة العامة .

لينش، ب و هـ. فهمى ع^ه 1. . العاملات البيدويات فى كرد/ست مصر: انتاج الاسرة المعيشية والاجباب. جينيف: منظمة العمل الدولية .

ماكليود، أ. بو9 1. العلاقات المهيمنه ومقاومة النوع: التحجب الجديد والتكيف مـع الاحتجـاج فى القاهرة."

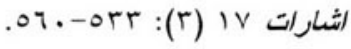

مـاكليو د، أ. . 199 ا. التكيف مـع الاحتجـاج: النساء العاملات، والتحجب الجديـــ والتغيسير فـى القـاهرة. نيويورك: مطبعة جامعة كولومبيا.

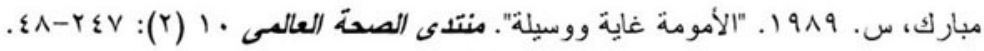

مجلس السكان الدولسى: مشروع بحوث العمليـات و المشـورة الفنيـة لمنطقة آسيا و الشـرق الادنى. 1990. تحسين المشورة والرعاية الصحية لمرضى ما بعد الاجهاض فى مصر. القاهرة، مجلس السكان الدولى ولى

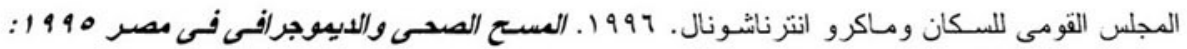
تقرير اولى. القاهرة: المجلس القومى للسكان .

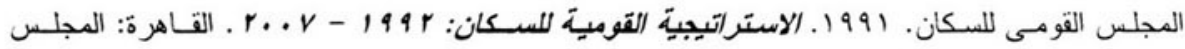

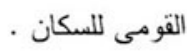

مجمو عة الاتصال من اجل تعزيز مكانة النساء فى مصر . ب99 ا ـ الحققق القانونية للنساء المصريات بين النظريتة والواقع. القاهرة .

مجمو عة من النساء المهتمـات. ـ191 1. "الحقوق القانونيـة للنسـاء المصريـات: النظريـة و التطبيـق". ترجمة انجليزية لورقة غير منشورة. القاهرة .

محسن، س. .910 1. "صور جديدة و أفكار قديمة: نساء الطبقة المتَوسطه العاملات فى مصر ." فى النساء

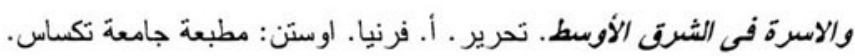


محسن، س. . .99. . "النساء و القضاء الجنائى فى مصر ." القانون والاسلام فى الشـرق الأوسط. تحريـر د. دو اير · نيويورك: بيرجين وجارفى .

مختار ، أ. وأ. مصطفى بو9 ا. "تتظيم الاسرة". ورقة مقدمة للمؤتمر القومسى حول نتائج مسح صحسة الام

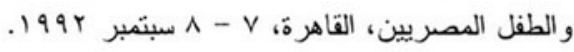

مدكور ، م. س. و 1 ا. "النساء المصريات بعملن". ورقة مقدمة للمؤتمر السنوى الذـامس للمنظمـة العالميـة

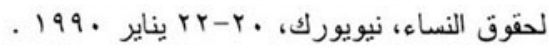

المكتب المرجعى للسكان. .991 ـ ملفص مشروع الخيارات: مصر ـ و اشنطون: المكتب المرجعى للسكان .

الموجى، م. أ. هنداوى، وم. هـ. جمعة، أ. الابحر ، أ. شـوبير ور . م. حنفى و . م. الثـافعى. "انمـاط خاصـة

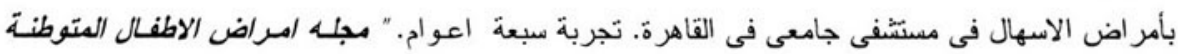
.

مور لاند، س.، ن. نجيب، ف. الزناتى، ك، او لسون، وأ. عبدالله. ب99 أ. "الاولوية للاطفال: انفاق الاسرة

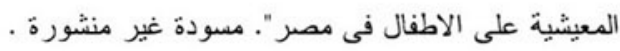

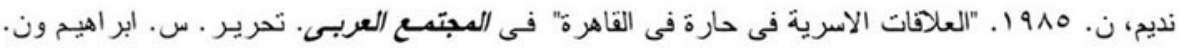

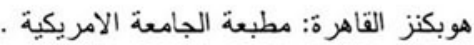

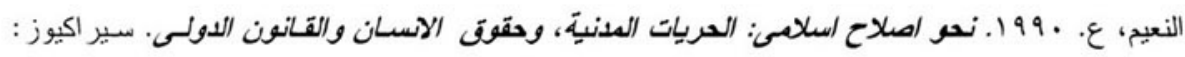

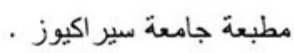

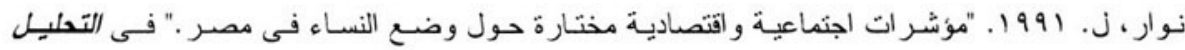

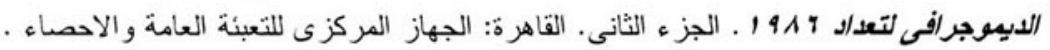

نو ار ، ل. و وآخرون 19901. "استقلالية النساء و الادوار الخاصة بالنوع فى الاسـر المصريـة". في السياسـات

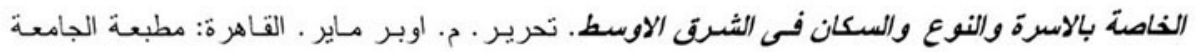
الامريكية .

النويحى، م. 9v9 1. "تغير قـانون الاحـوال الثـخصية مـن خـلال التفسير الليبر الى للثـريعة. "فى القانون

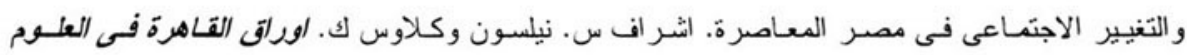

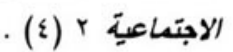


هاربيسون، س. 990 1. "الحاجة غير الملباة لنتظيع الاسرة: تحدى للمستثبل" فى وجهات نظر حول الخصوية

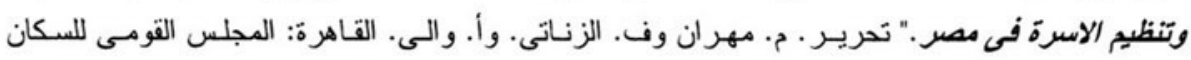

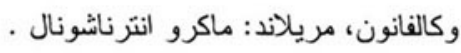

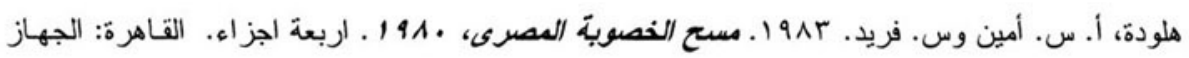

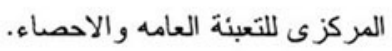

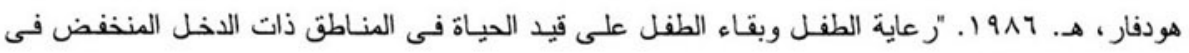

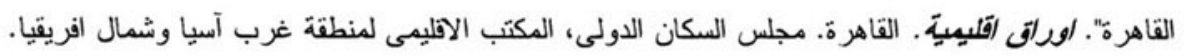
هودفار . "ميز انية الاسرة المعيشية والادارة المالية فى احدى مناطق الدخل المنذفض فى القاهرة". فـى منزل

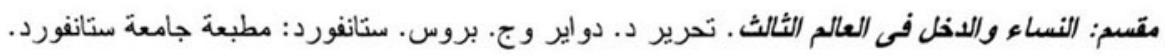
هودفار . .99 1". استر اتيجيات البقاء على قيد الحياة فى الاسر المعيشية ذات الدخل المنخفض في القاهرة.

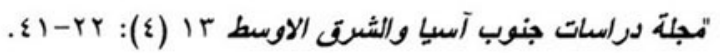

هودفار . 1991 . "العوده للحجاب: الاستر اتيجية الخاصة و المشاركة العامة فى مصر ." فى نساء عاملات:

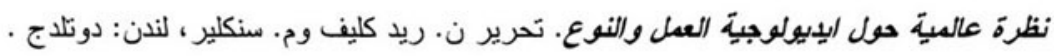

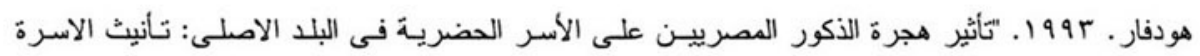

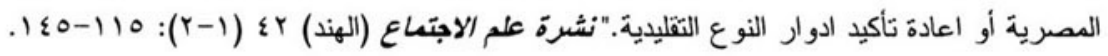
هوفمان، ف. 919 1. "مسلمة نشطة: زينب الغز الـى" فى النساء والاسرة فى الشرق الاوسط. تحرير أ.

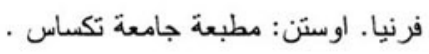
هيئة نو عية البينة الدولية. 1911 ا . "مشروع توليد الدخل للأسـرة المعيشية التى تر أسها امر أة." ورقهـ غير

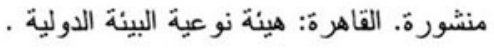

وزارة التعليم (جمهوريـة مصر العربية). ب991 1. (حصائيات تعليمية 1911 - 1991 ـ القاهرة: وزارة · التعليم

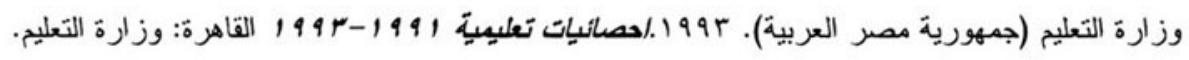

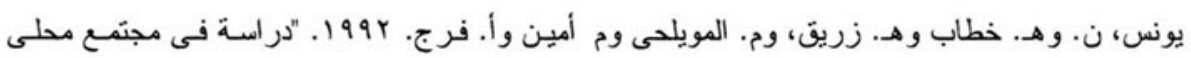

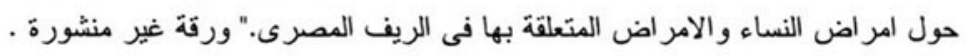

اليونسكو. ـ 199 ا.كتاب الاحصاء السنوى. باريس. 
Designed \& Printed

By

Green Leaf Art Studio 